ERNEST

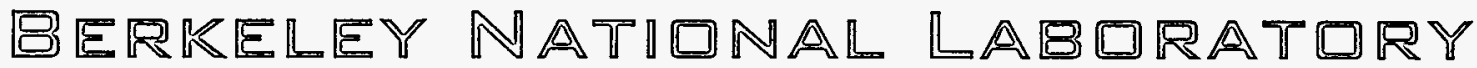

\title{
Cooling Energy Savings Potential of Light-Colored Roofs for Residential and Commercial Buildings in 11 U.S. Metropolitan Areas
}

S. Konopacki, H. Akbari, M. Pomerantz, S. Gabersek, and L. Gartland Environmental Energy Technologies Division

May 1997
RECEIVED

JUL 311997

O \&.T

ASTEP 


\section{DISCLAIMER}

This document was prepared as an account of work sponsored by the United States Government. While this document is believed to contain correct information, neither the United States Government nor any agency thereof, nor The Regents of the University of California, nor any of their employees, makes any warranty, express or implied, or assumes any legal responsibility for the accuracy, completeness, or usefulness of any information, apparatus, product, or process disclosed, or represents that its use would not infringe privately owned rights. Reference herein to any specific commercial product, process, or service by its trade name, trademark, manufacturer, or otherwise, does not necessarily constitute or imply its endorsement, recommendation, or favoring by the United States Government or any agency thereof, or The Regents of the University of California. The views and opinions of authors expressed herein do not necessarily state or reflect those of the United States Government or any agency thereof, or The Regents of the University of California.

This report has been reproduced directly from the best available copy.

Available to DOE and DOE Contractors from the Office of Scientific and Technical Information

P.O. Box 62, Oak Ridge, TN 37831

Prices available from (615) $576-8401$

Available to the public from the National Technical Information Service

U.S. Department of Commerce

5285 Port Royal Road, Springfield, VA 22161

Ernest Oriando Lawrence Berkeley National Laboratory

is an equal opportunity employer. 
LBNL-39433

UC-000

\title{
Cooling Energy Savings Potential of Light-Colored Roofs for Residential and Commercial Buildings in 11 U.S. Metropolitan Areas
}

\author{
S. Konopacki, H. Akbari, M. Pomerantz, S. Gabersek, and L. Gartland \\ Heat Island Project \\ Environmental Energy Technologies Division \\ Lawrence Berkeley National Laboratory \\ University of California \\ Berkeley, CA 94720
}

A Report Prepared for

The Environmental Protection Agency

May 1997

\footnotetext{
This work was sponsored by the U.S. Environmental Protection Agency through the U.S. Department of Energy, Under contract DE-AC0376SF00098.
} 


\section{DISCLAIMIER}

Portions of this document may be illegible in electronic image products. Images are produced from the best available original document. 


\section{Table of Contents}

Table of Contents . . . . . . . . . . . . . . . . . . . . . . . . . . . . . . . .

List of Figures . . . . . . . . . . . . . . . . . . . . . . . . . . . . . . . . c c 3

List of Tables . . . . . . . . . . . . . . . . . . . . . . . . . . 4

Acknowledgement . . . . . . . . . . . . . . . . . . . . . . . . 47

Abstract . . . . . . . . . . . . . . . . . . . . . . . . . . . 8

Executive Summary . . . . . . . . . . . . . . . . . . . . . . . . . 9

1. Introduction . . . . . . . . . . . . . . . . . . . . . . . . . . . . . 17

Background . . . . . . . . . . . . . . . . . . . . . . 17

Objective . . . . . . . . . . . . . . . . . . . . . . . 17

Methodology . . . . . . . . . . . . . . . . . . . . . . . 18

2. Roof Albedo . . . . . . . . . . . . . . . . . . . . . . . . . . . . . $\quad . \quad 21$

3. Building-Scale HVAC Energy and Monetary Base Use and Savings . . . . . . . 22

DOE-2 Building Prototypes . . . . . . . . . . . . . . . . . . 22

Roof/Attic/Ceiling Model . . . . . . . . . . . . . . . . . . . 22

Electricity and Gas Prices . . . . . . . . . . . . . . . . . . . . . . . . $\quad$. 24

DOE-2 Simulated HVAC Electricity, Natural Gas, and Net Energy Base Use . . . $\quad 24$

DOE-2 Simulated HVAC Electricity, Natural Gas, and Net Energy Savings ～. . . $\quad 24$

DOE-2 Simulated HVAC Electricity, Natural Gas, and Net Energy Savings by

Climate . . . . . . . . . . . . . . . . . . . . . . . . . 29

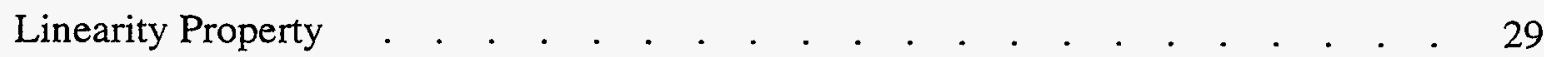

Discussion . . . . . . . . . . . . . . . . . . . . . . . . 31

4. Building Stock and Roof Area . . . . . . . . . . . . . . . . . . . . . . . . 32

Residential . . . . . . . . . . . . . . . . . . . . . . . 32

Commercial . . . . . . . . . . . . . . . . . . . . . . . . 32

Summary . . . . . . . . . . . . . . . . . . . . . . . . 33

5. Metropolitan-Scale and National HVAC Energy and Monetary Savings . . . . . . 35

Savings in Eleven Metropolitan Statistical Areas . . . . . . . . . . . 35

National Savings . . . . . . . . . . . . . . . . . . . . . . 36

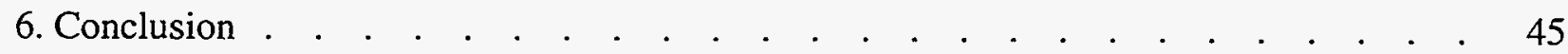

Bibliography . . . . . . . . . . . . . . . . . . . . . . . . . . . 47

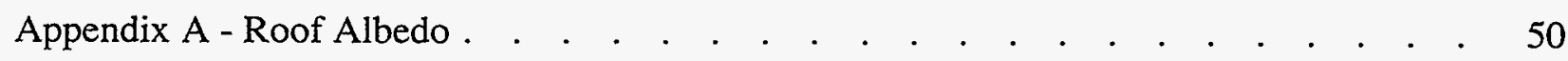

Albedo Retrieval Procedure . . . . . . . . . . . . . . . . . . 50

Data and Processing . . . . . . . . . . . . . . . . . . . . . . . . 51

Calibration of Grayness vs. Albedo . . . . . . . . . . . . . . . . . . 54

Discussion . . . . . . . . . . . . . . . . . . . . . . . . 58

Appendix B - Building-Scale HVAC Energy and Monetary Data . . . . . . . . . 59

Weather and Price of Energy Data . . . . . . . . . . . . . . . . . 59

DOE-2 Building Prototype Characteristics and Simulation Results . . . . . . 60 
DOE-2 Simulated HVAC Electricity, Natural Gas, and Net Energy Savings by

Climate .

Appendix C - Building Stock and Roof Area Data

Appendix D - Metropolitan-Scale HVAC Energy and Monetary Data 102

Appendix E - National Estimates of HVAC Energy and Monetary Savings . . . . . . . 106

Extrapolation by Climate Zone . . . . . . . . . . . . . . . . . 106

Extrapolation by Population . . . . . . . . . . . . . . . . . 109

Metropolitan-Scale and National HVAC Energy and Monetary Base Use . . . . 109

Attachment 1 - Residential White Roofing Shingles . . . . . . . . . . . . . 112

Attachment 2 - Linearity Property . . . . . . . . . . . . . . . . . . 113 


\section{List of Figures}

Figure

Description

Page

Figure EX-1. Annual net energy savings in millions of dollars and in dollars per $1000 \mathrm{ft}^{2}$ roof area of air-conditioned buildings..

Figure EX-2. Annual cooling electricity savings in gigawatt hour $(\mathrm{GWh})$ and in watt hour (Wh) per $1000 \mathrm{ft}^{2}$ roof area of air-conditioned buildings. . . . . 14

Figure EX-3. Annual natural gas deficit in gigaBtu (GBtu) and in therms ( 1 therm $=10^{5} \mathrm{Btu}$ ) per $1000 \mathrm{ft}^{2}$ roof area of air-conditioned buildings. . .

Figure EX-4. Peak electricity demand savings in megawatt (MW)and in watt $(\mathrm{W})$ per $1000 \mathrm{ft}^{2}$ roof area of air-conditioned buildings.

Figure 1-1. Methodology to obtain building- and metropolitan-scale energy savings.

Figure 3-1. DOE-2 simulated HVAC annual net energy savings from light-colored roofs for single-story old and new residences, offices, and retail stores, all with gas furnace heating.

Figure 5-1. Annual net energy savings in millions of dollars and in dollars per $1000 \mathrm{ft}^{2}$ roof area of air-conditioned buildings.

Figure 5-2. Annual cooling electricity savings in in gigawatt hour (GWh) and in watt hour (Wh) per $1000 \mathrm{ft}^{2}$ roof area of air-conditioned buildings.

Figure 5-3. Annual natural gas deficit in gigaBtu (GBtu) and in therms ( 1 therm $=10^{5} \mathrm{Btu}$ ) per $1000 \mathrm{ft}^{2}$ roof area of air-conditioned buildings. . . .

Figure 5-4. Peak electricity demand savings in megawatt (MW)and in watt (W) per $1000 \mathrm{ft}^{2}$ roof area of air-conditioned buildings. . . . . . . . 43

Figure A-1. Sub-image containing residential buildings in Atlanta with $1 \mathrm{~m}$ resolution. . . $\quad 52$

Figure A-2. Sub-image containing commercial buildings in Atlanta with $1 \mathrm{~m}$ resolution. . $\quad 53$

Figure A-3. Plot of fitted linear model. . . . . . . . . . . . . . . . . . 56

Figure A-4. Plot of fitted square root model. . . . . . . . . . . . . . . . 56

Figure A-5. Relative frequency histogram for distribution of grayness of residential building's roofs. . . . . . . . . . . . . . . . . . . 57

Figure A-6. Relative frequency histogram for distribution of grayness of commercial building's roofs. . . . . . . . . . . . . . . . . . . 57

Figure B-1. DOE-2 simulated HVAC annual electricity savings from light-colored roofing.. $\quad 86$

Figure B-2. DOE-2 simulated HVAC annual natural gas deficit from light-colored roofing.. $\quad 89$

Figure B-3. DOE-2 simulated HVAC annual net energy savings from light-colored roofing. $\quad 91$

Figure B-4. DOE-2 simulated HVAC peak electricity demand savings from light-colored roofing. 


\section{List of Tables}

Table

Description

Page

Table EX-1.Estimates of metropolitan-scale annual direct cooling electricity savings, annual natural gas penalty, net dollar savings, and peak electricity demand savings, resulting from application of light-colored roofing on residential and commercial buildings in 11 Metropolitan Statistical Areas.

Table EX-2.Estimates of annual direct savings and penalties per $1000 \mathrm{ft}^{2}$ of roof area of air-conditioned buildings resulting from application of light-colored roofing on residential and commercial buildings in 11 Metropolitan Statistical Areas. . . . . . . . . . . . . . . . . . . .

Table 1-1. 1990 populations of U.S. Consolidated Metropolitan Statistical Areas (CMSA) and Metropolitan Statistical Areas (MSA) for 11 urban heat island locations. .

Table 2-1. Average roof albedo for existing residential and commercial buildings from analysis of digitized aerial photographs taken over Atlanta, Washington DC, and Philadelphia.

Table 3-1. Prototypical building HVAC system and construction characteristics..

Table 3-2. DOE-2 simulated HVAC base use and savings from light-colored roofing for single-story residences, offices, and retail stores; annual electricity and net energy, peak electricity demand, and annual natural gas are estimated per $1000 \mathrm{ft}^{2}$ of flat roof area.

Table 3-3. DOE-2 simulated HVAC base and modified case annual energy cost estimates for single-story buildings modeled with gas furnace heating expressed in dollars per $1000 \mathrm{ft}^{2}$ of flat roof area.. . . . . . . . . . . . . . . . 28

Table 4-1. Conditioned flat roof area of residential and commercial building stock. . . . 34

Table 5-1. Estimates of metropolitan-scale annual direct cooling electricity savings, annual natural gas penalty, net dollar savings, and peak electricity demand savings, resulting from application of light-colored roofing on residential and commercial buildings in 11 Metropolitan Statistical Areas.

Table 5-2. Estimates of annual direct savings and penalties per $1000 \mathrm{ft}^{2}$ of roof area of air-conditioned buildings resulting from application of light-colored roofing on residential and commercial buildings in 11 Metropolitan Statistical Areas. . . . . . . . . . . . . . . . .

Table 5-3. Potential national energy savings resulting from the application of light-colored roofs to residential and commercial buildings. . . . . . . . 44

Table A-1. Albedo and Grayness Values for Surfaces in Atlanta. . . . . . . . . . 55

Table A-2. Estimated average roof albedos of residences and commercial buildings 
and sample size for Atlanta, Philadelphia, and Washington, DC. . . . . 55

Table B-1. Weather tapes used for DOE-2 simulations and typical weather year (TMY) data of 11 Metropolitan Statistical Areas. . . . . . . . . . . . 59

Table B-2. Average 1993 prices of electricity and natural gas. . . . . . . . . . 59

Table B-3. Single-family residential prototype characteristics. . . . . . . . . . 61

Table B-4. Single-family residential prototype local HVAC capacities. . . . . . . . . 62

Table B-5. Office prototype characteristics. . . . . . . . . . . . . . . . 63

Table B-6. Office prototype zonal and local HVAC capacities. . . . . . . . . . 64

Table B-7. Retail store prototype characteristics. . . . . . . . . . . . . . 65

Table B-8. Retail store prototype local HVAC capacities. . . . . . . . . . . . . . 66

Table B-9. Primary school prototype characteristics. . . . . . . . . . . . . 67

Table B-10. Primary school prototype zonal and local HVAC capacities. . . . . . . 68

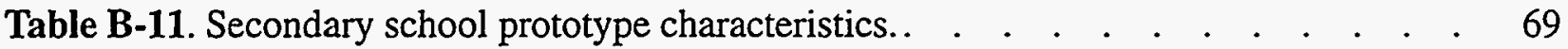

Table B-12. Secondary school prototype zonal and local HVAC capacities. . . . . . . 70

Table B-13. Hospital prototype characteristics.. . . . . . . . . . . . . . . 71

Table B-14. Hospital prototype zonal and local HVAC capacities. . . . . . . . . . 72

Table B-15. Nursing home prototype characteristics. . . . . . . . . . . . . . . 73

Table B-16. Nursing home prototype zonal and local HVAC capacities. . . . . . . . 74

Table B-17. Grocery store prototype characteristics. . . . . . . . . . . . . . 75

Table B-18. Grocery store prototype zonal and local HVAC capacities. . . . . . . 76

Table B-19. DOE-2 simulated HVAC base use and savings from light-colored roofing; annual electricity and net energy, peak electricity demand, and annual natural gas estimated per $1000 \mathrm{ft}^{2}$ of flat roof area. . . . . . . . . . 77

Table C-1. Residential building stock data for determination of conditioned flats roof area. . . . . . . . . . . . . . . . . . . . 97

Table C-2. Metropolitan area and census division population for calculation of commercial conditioned flat roof area. . . . . . . . . . . . . 98

Table C-3. Total and conditioned flat roof area of residential and commercial building stock. .

Table D-1. Metropolitan-scale HVAC annual electricity and net energy savings, peak electricity demand savings, and annual natural gas deficit estimates from light-colored roofing for residential and commercial buildings in 11 U.S. Metropolitan Statistical Areas. .

Table E-1. Climate zone extrapolated estimates of annual national energy (M\$), electricity (GWh), gas (GBtu), and peak electricity (MW) savings potentials 
of reflective roofs in the residential sector. . . . . . . . . . . . 107

Table E-2. Climate zone extrapolated estimates of annual national Energy (M\$), electricity (GWh), gas (GBtu), and peak electricity (MW) savings potentials of reflective roofs in residential and commercial sectors. . . . . . . . 108

Table E-3. Metropolitan-scale HVAC annual electricity, natural gas, and net energy and peak electricity demand base use (dark roof) estimates for residential, office, retail store, and (schools, health, and grocery store) buildings in 11 U.S. Metropolitan Statistical Areas. . . . . 110

Table E-4. Eleven metropolitan area sum total and population extrapolated national estimates of HVAC energy base use and savings resulting from light-colored roofs on residential and commercial buildings. . . . . . 111 


\section{Acknowledgement}

This work was sponsored by the U.S. Environmental Protection Agency through the U.S. Department of Energy, Under contract DE-AC0376SF00098. We wish to thank Linda Latham of EPA for her support and review; Mithra Moezzi of Lawrence Berkeley National Laboratory (LBNL) for her contribution; Sarah Bretz (LBNL), Arthur Rosenfeld (DOE). Joe Huang (LBNL), and Danny Parker of the Florida Solar Energy Center (FSEC) for their reviews. 


\begin{abstract}
Light-colored roofs reflect more sunlight than dark roofs, thus they keep buildings cooler and reduce air-conditioning demand. Typical roofs in the United States are dark, which creates a potential for saving energy and money by changing to reflective roofs. In this report, we make quantitative estimates of the impact of roof color by simulating prototypical buildings with lightand dark-colored roofs and calculating savings by taking the differences in annual cooling and heating energy use, and peak electricity demand. Monetary savings are calculated using local utility rates. Savings are estimated for 11 U.S. Metropolitan Statistical Areas (MSAs) in a variety of climates. We used the DOE-2 building energy simulation program for these calculations.

Estimates of savings for an entire MSA is obtained by scaling the savings for the prototypical buildings with the total air-conditioned space in each MSA. The largest potential for net annual energy cost savings were found in Phoenix (\$37M [\$34 per $1000 \mathrm{ft}^{2}$ roof area of air-conditioned buildings]), followed by Los Angeles (\$35M [\$20]), Houston (\$27M [\$18]), Miami/Fort Lauderdale (\$20M [\$21]), Dallas/Fort Worth (\$20M [\$11]), New York City (\$16M [\$17]), Chicago $(\$ 10 \mathrm{M}[\$ 9])$, New Orleans (\$9M [\$17]), Atlanta (\$9M [\$10]), Washington, DC/Baltimore (\$8M [\$5]), and Philadelphia (\$3M [\$4]). The totals for all $11 \mathrm{MSAs}$ were: total annual electricity savings, 2.6 terawatt hours (TWh); net energy savings, \$194M and peak electricity demand savings, 1.7 gigawatt (GW). Six building types accounted for over $90 \%$ of the annual electricity and net energy savings: old residences were responsible for almost $55 \%$, new residences $15 \%$, and four other building types (old/new offices and old/new retail stores) together almost $25 \%$. Extrapolating the savings from the 11 MSAs to the entire United States, we estimated annual electricity savings of about $10 \mathrm{TWh}$ and a net savings of about $\$ 750 \mathrm{M}$ in annual energy payments. Peak electricity power reduction was estimated to be about $7 \mathrm{GW}$.
\end{abstract}




\section{Executive Summary}

The U.S. Environmental Protection Agency (EPA) sponsored this project to estimate potential energy and monetary savings resulting from the implementation of light-colored roofs on residential and commercial buildings in major U.S. metropolitan areas. Light-colored roofs reflect more sunlight than dark roofs, so they keep buildings cooler and reduce air-conditioning demand. Typically, rooftops in the United States are dark, and thus there is a potential for saving energy and money by changing to reflective roofs. Naturally, the expected savings are higher in southern, sunny, and cloudless climates. In this study, we make quantitative estimates of reduction in peak power demand and annual cooling electricity use that would result from increasing the reflectivity of the roofs. Since light-colored roofs also reflect heat in the winter, the estimates of annual electricity savings are a net value corrected for the increased wintertime energy use. Savings estimates only include direct reduction in building energy use and do not account for the indirect benefit that would also occur from the reduction in ambient temperature, i.e. a reduction in the heat island effect.

This analysis is based on simulations of building energy use, using the DOE-2 building energy simulation program. Our methodology starts with specifying 11 prototypical buildings: $\dagger$ singlefamily residential (old and new), office (old and new), retail store (old and new), school (primary and secondary), health (hospital and nursing home), and grocery store. Most prototypes are simulated with two heating systems: gas furnace and heat pumps. We then perform DOE-2 simulations of the prototypical buildings, with light and dark roofs, in a variety of climates and obtain estimates of the energy use for air conditioning and heating. Weather data for 11 U.S. Metropolitan Statistical Areas (MSAs) are used: Atlanta, Chicago, Los Angeles, Dallas/Fort Worth, Houston, Miami/Fort Lauderdale, New Orleans, New York City, Philadelphia, Phoenix, and Washington, DC/Baltimore. Cooling energy savings and heating energy penalties are then obtained by calculating the difference between the simulated energy use of the prototype buildings with lightand dark-colored roofs.

We proceed from the estimates of savings in individual buildings to the entire MSA, by calculating how much energy and money could be saved if the current building stock had its roofs changed from dark to light. This is done by scaling the simulated energy savings of the prototype buildings by the amount of air-conditioned space immediately beneath roofs in an entire MSA. For this, we use data in each MSA on the stock of commercial and residential buildings, the saturation of heating and cooling systems, the current roof reflectivities, and the local costs of electricity and gas.

The estimates of the direct savings are shown in Table EX-1. The largest potential for net annual dollar savings was found in Phoenix, $\$ 37$ million $(\$ 37 \mathrm{M})$, followed by Los Angeles $(\$ 35 \mathrm{M})$, Houston $(\$ 27 \mathrm{M})$, Miami/Fort Lauderdale $(\$ 20 \mathrm{M})$, Dallas/Fort Worth $(\$ 20 \mathrm{M})$, New York

$\dagger$ In a multi-story building, only the top floor which is directly affected by the roof color is included. 
City $(\$ 16 \mathrm{M})$, Chicago $(\$ 10 \mathrm{M})$, New Orleans $(\$ 9 \mathrm{M})$, Atlanta $(\$ 9 \mathrm{M})$, Washington, DC/Baltimore $(\$ 8 \mathrm{M})$, and Philadelphia $(\$ 3 \mathrm{M})$. The same quantities per $1000 \mathrm{ft}^{2}$ of roof area of air-conditioned buildings for each MSA are shown in Table EX-2. To illustrate the climate effect, the results are plotted in Figures EX-1 to EX-4, superimposed on a map of the United States with contours of annual cooling hours for a typical residential building. The data per $1000 \mathrm{ft}^{2}$ of roof area reflect the effects of climate, whereas the MSA savings are strongly affected by the sizes of the populations.

The sum total for all 11 MSAs are: electricity savings, 2.6 terawatt hours (TWh) (200 kilowatt hours per $1000 \mathrm{ft}^{2}$ of roof area of air-conditioned buildings); natural gas deficit, 6.9 TBtu (5 therms per $\left.1000 \mathrm{ft}^{2}\right)$; net savings in energy bills, $\$ 194 \mathrm{M}\left(\$ 15\right.$ per $\left.1000 \mathrm{ft}^{2}\right)$; and savings in peak demand 1.7 gigawatt (GW) ( $135 \mathrm{~W}$ per $\left.1000 \mathrm{ft}^{2}\right)$. Six building types account for over $90 \%$ of the annual electricity and net dollar savings: old residences more than 55\%, new residences about $15 \%$, and four other building types (old/new offices and old/new retail stores) together about $25 \%$.

The results for the 11 MSAs are extrapolated to estimate the savings in the entire United States. This extrapolation is done first by scaling to the national population, and then by a method that accounts for the climatic variations of the savings. We find that the national savings are about four times the savings for the 11 MSAs: a decrease in annual direct electricity use by 9.3 to 11 TWh (about $3.0 \%$ of the national cooling electricity use in residential and commercial buildings), an increase in natural gas use by 25 to $28 \mathrm{GBtu}(1.6 \%)$, decrease peak electrical demand by 6.2 to $7.2 \mathrm{GW}(2.5 \%$ ) (equivalent to 12 to 14 power plants each with a capacity of $0.5 \mathrm{GW}$ ), and a decrease in net energy bills for the rate-payers by $\$ 680 \mathrm{M}$ to $\$ 850 \mathrm{M}$. 
Table EX-1. Estimates of metropolitan-scale annual direct cooling electricity savings, annual natural gas penalty, net dollar savings, and peak electricity demand savings, resulting from application of light-colored roofing on residential and commercial buildings in 11 Metropolitan Statistical Areas. Net dollar savings are calculated using the local cost of electricity and gas. For example, in Phoenix, the average price of electricity and gas for commercial and residential consumers are: $1 \mathrm{kWh}$ costs $\$ 0.104$; and $1 \mathrm{MBtu} \$ 6.40$.

\begin{tabular}{|c|c|c|c|c|c|c|c|c|c|c|c|c|c|c|c|c|c|c|}
\hline \multirow[b]{2}{*}{ Metropolitan Area } & \multicolumn{6}{|c|}{ Residential Savings } & \multicolumn{6}{|c|}{ Commercial Savings } & \multicolumn{6}{|c|}{ Residential and Commercial Savings } \\
\hline & $\begin{array}{r}\text { el } \\
\text { (GWh }\end{array}$ & ec & $\begin{array}{r}\text { ga } \\
\text { (GBtu) } \\
\end{array}$ & is & $\begin{array}{c}\text { net } \\
\text { (M\$) }\end{array}$ & $\begin{array}{l}\text { peak } \\
(\mathrm{MW})\end{array}$ & $\begin{array}{r}\text { ele } \\
(G W h) \\
\end{array}$ & $(\mathrm{M} \$)$ & $\begin{array}{r}\mathrm{ga} \\
\text { (GBtu) } \\
\end{array}$ & s & $\begin{array}{l}\text { net } \\
\text { (M\$) }\end{array}$ & $\begin{array}{l}\text { peak } \\
\text { (MW) }\end{array}$ & $\begin{array}{r}\text { ele } \\
(G W h)\end{array}$ & ec & $\begin{array}{r}\mathrm{ga} \\
(\mathrm{GBtu})\end{array}$ & $(\mathrm{M} \$)$ & $\begin{array}{c}\text { net } \\
(M \$)\end{array}$ & $\begin{array}{l}\text { peak } \\
\text { (MW }\end{array}$ \\
\hline Atlanta & 125 & 9.8 & -349 & -2.4 & 7.4 & 83 & 22 & 1.6 & -55 & $|-0.3|$ & 1.3 & 14 & 147 & 11.4 & -404 & -2.7 & 8.7 & 97 \\
\hline Chicago & 100 & 11.2 & -988 & -5.4 & 5.8 & 89 & 84 & 7.0 & -535 & -2.7 & 4.3 & 56 & 183 & 18.2 & -1523 & $\mid-8.1$ & 10.1 & 145 \\
\hline Los Angeles & 210 & 20.6 & -471 & -2.9 & 17.7 & 218 & 209 & 18.6 & -154 & -0.9 & 17.7 & 102 & 419 & 39.2 & -625 & -3.8 & J0.4 & 320 \\
\hline Dallas / Ft Worth & 241 & 18.6 & -479 & -2.8 & 15.8 & 175 & 71 & 4.5 & -113 & -0.5 & 4.0 & 36 & 312 & 23.1 & -592 & -3.3 & 19.8 & 811 \\
\hline Houston & 243 & 22.6 & -284 & -1.7 & 20.9 & 127 & 79 & 6.0 & -62 & $-0.3 \mid$ & 5.7 & 30 & 322 & 28.6 & -347 & -2.0 & 26.6 & 156 \\
\hline Miami / Ft Lauderdale & 221 & 17.9 & -4 & 0.0 & 17.9 & 115 & 35 & 2.4 & -3 & 0.0 & 2.4 & 11 & 256 & 20.3 & -7 & 0.0 & 20.3 & 3) 125 \\
\hline New Orleans & 84 & 6.6 & -107 & -0.7 & 5.9 & $27 \|$ & 33 & 2.8 & -28 & -0.1 & 2.7 & 16 & 117 & 9.4 & -135 & -0.8 & 8.6 & 42 \\
\hline New York & 35 & 5.6 & -331 & -2.7 & 2.9 & 56 & 131 & 16.5 & -540 & -3.3 & 13.2 & 95 & 166 & 22.1 & -871 & -6.0 & 16.1 & 151 \\
\hline Philadelphia & 44 & 5.6 & -954 & -6.5 & -0.9 & 108 & 47 & 5.5 & -292 & -1.8 & 3.7 & 49 & 91 & 11.1 & -1246 & -8.3 & 2.8 & 157 \\
\hline Phoenix & 299 & 32.0 & -74 & $-0.5 \mid$ & 31.5 & 106 & 58 & 5.3 & -31 & $-0.2 \mid$ & 5.1 & 18 & 357 & 37.3 & -105 & -0.7 & 36.6 & 123 \\
\hline DC/ Baltimore & 182 & 13.1 & -845 & -7.0 & 6.1 & 183 & 45 & 3.2 & -184 & -1.1 & 2.1 & 31 & 227 & 16.3 & -1029 & -8.1 & 8.2 & 2) 214 \\
\hline Total & 1784 & 163.6 & -4886 & -32.6 & 131.0 & 1287 & 814 & 73.4 & 1997 & 11.2 & 62.2 & 458 & 2597 & 237.0 & 6884 & 43.8 & 193.2 & $\begin{array}{l}2 \\
2\end{array}$ \\
\hline
\end{tabular}


Table EX-2. Estimates of annual direct savings and penalties per $1000 \mathrm{ft}^{2}$ of roof area of air-conditioned buildings resulting from application of light-colored roofing on residential and commercial buildings in 11 Metropolitan Statistical Areas. Net dollar savings are calculated using the local cost of electricity and gas. For example, in Phoenix, the average price of electricity and gas for commercial and residential consumers are: $1 \mathrm{kWh}$ costs $\$ 0.104$; and 1 therm $=0.1 \mathrm{MBtu}$ costs $\$ 0.64$.

\begin{tabular}{|c|c|c|c|c|c|c|c|c|c|c|c|c|}
\hline \multirow[b]{2}{*}{ Metropolitan Area } & \multicolumn{4}{|c|}{ Residential Savings } & \multicolumn{4}{|c|}{ Commercial Savings } & \multicolumn{4}{|c|}{ Residential and Commercial Savings } \\
\hline & $\begin{array}{c}\text { elec } \\
(\mathrm{kWh})\end{array}$ & $\begin{array}{c}\text { gas } \\
\text { (therms) } \\
\end{array}$ & $\begin{array}{r}\text { net } \\
(\$) \\
\end{array}$ & $\begin{array}{r}\text { peak } \\
(\mathrm{W}) \\
\end{array}$ & $\begin{array}{c}\text { elec } \\
(\mathrm{kWh}) \\
\end{array}$ & $\begin{array}{c}\text { gas } \\
\text { (therms) } \\
\end{array}$ & $\begin{array}{r}\text { net } \\
(\$) \\
\end{array}$ & $\begin{array}{l}\text { peak } \\
(\mathrm{W}) \\
\end{array}$ & $\begin{array}{c}\text { elec } \\
(\mathrm{kWh}) \\
\end{array}$ & $\begin{array}{c}\text { gas } \\
\text { (therms) } \\
\end{array}$ & $\begin{array}{l}\text { net } \\
(\$)\end{array}$ & $\begin{array}{l}\text { peak } \\
(\mathrm{W}) \\
\end{array}$ \\
\hline Atlanta & 153 & -4 & 10 & 102 & 239 & -6 & 11 & 152 & 162 & -4 & 10 & 107 \\
\hline Chicago & 131 & -13 & 8 & 116 & 228 & -15 & 11 & 152 & 162 & -13 & 9 & 128 \\
\hline Los Angeles & 182 & -4 & 16 & 189 & 350 & -3 & 30 & 171 & 239 & -4 & 20 & 183 \\
\hline Dallas / Ft Worth & 166 & -3 & 11 & 121 & 224 & -4 & 13 & 114 & 176 & -3 & 11 & 119 \\
\hline Houston & 198 & -2 & 17 & 103 & 261 & -2 & 20 & 99 & 211 & -2 & 18 & 102 \\
\hline Miami / Ft Lauderdale & 259 & 0 & 21 & 135 & 340 & 0 & 19 & 107 & 267 & 0 & 21 & 131 \\
\hline New Orleans & 199 & -3 & 14 & 64 & 287 & -2 & 26 & 139 & 218 & -3 & 17 & 78 \\
\hline New York & 104 & -10 & 9 & 166 & 211 & -9 & 21 & 153 & 173 & -9 & 17 & 158 \\
\hline Philadelphia & 81 & -18 & -2 & 199 & 232 & -14 & 20 & 241 & 122 & -17 & 4 & 211 \\
\hline Phoenix & 314 & -1 & 34 & 111 & 409 & -2 & 35 & 127 & 327 & -1 & 34 & 113 \\
\hline DC / Baltimore & 137 & -6 & 5 & 138 & 221 & -9 & 10 & 152 & 148 & -7 & 5 & 140 \\
\hline
\end{tabular}




\section{Figure EX-1: Annual Net Dollar Savings for 11 Metropolitan Areas}

Net \$ Savings = \$ Cooling Energy Savings $-\$$ Heating Energy Penalties

The contour map shows simulated annual cooling hours for a typical house (Source: Kelly \& Parken 1978).

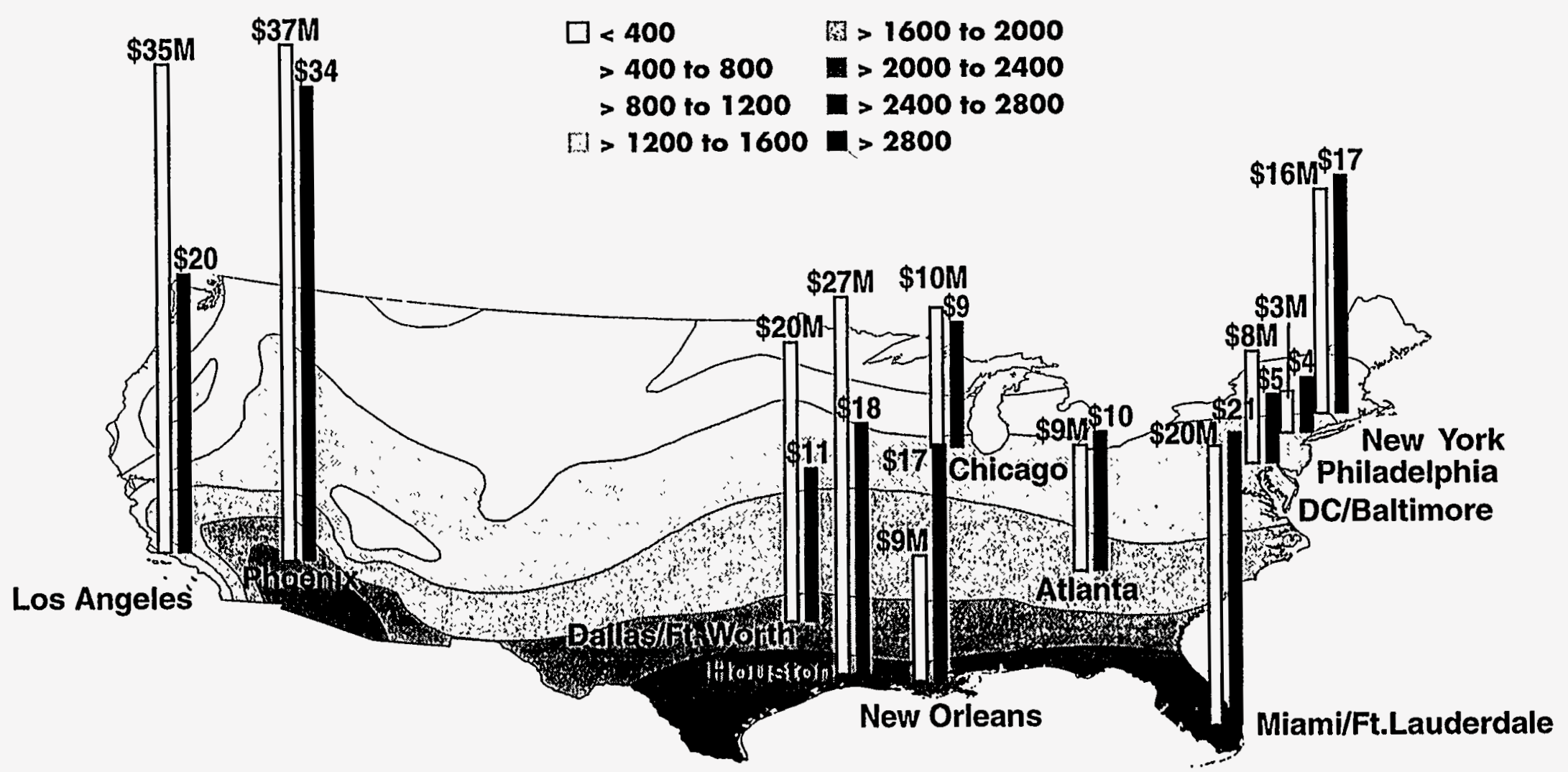

Metropolitan-scale savings (\$ millions)

Metropolitan-scale savings per $1000 \mathrm{ft}^{2}$ of roof area of air-conditioned buildings (\$) 


\section{Figure EX-2: Annual Cooling-Electricity Savings for 11 Metropolitan Areas}

The contour map shows simulated annual cooling hours for a typical house (Source: Kelly \& Parken 1978).

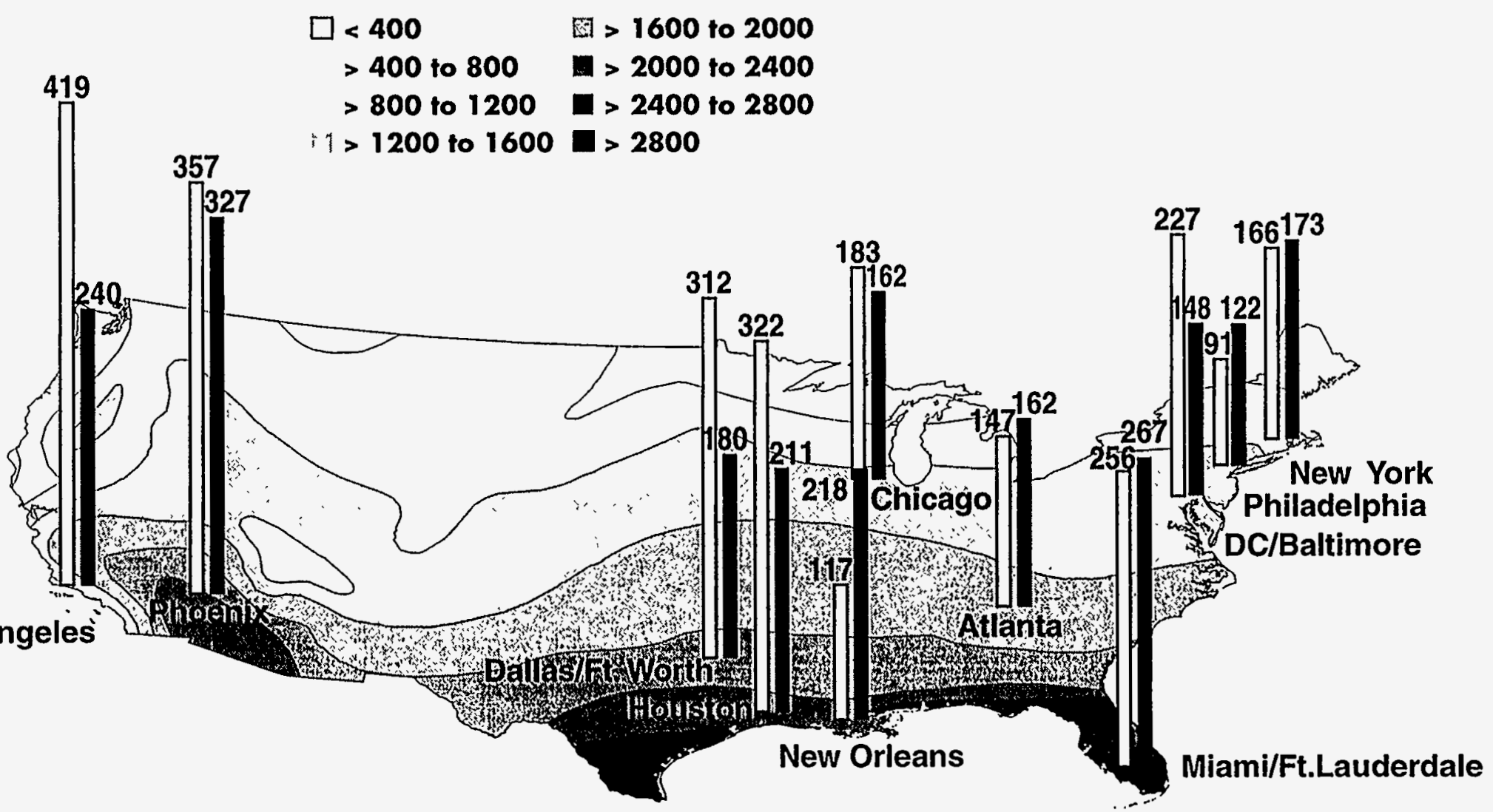

Los Angeles

Metropolitan-scale savings (GWh)

Metropolitan-scale savings per $1000 \mathrm{ft}^{2}$ of roof area of air-conditioned buildings (kWh) 


\section{Figure EX-3: Annual Heating Energy Penalties for 11 Metropolitan Areas}

The confour map shows simulated annual cooling hours for a typical house (Source: Kelly \& Parken 1978).

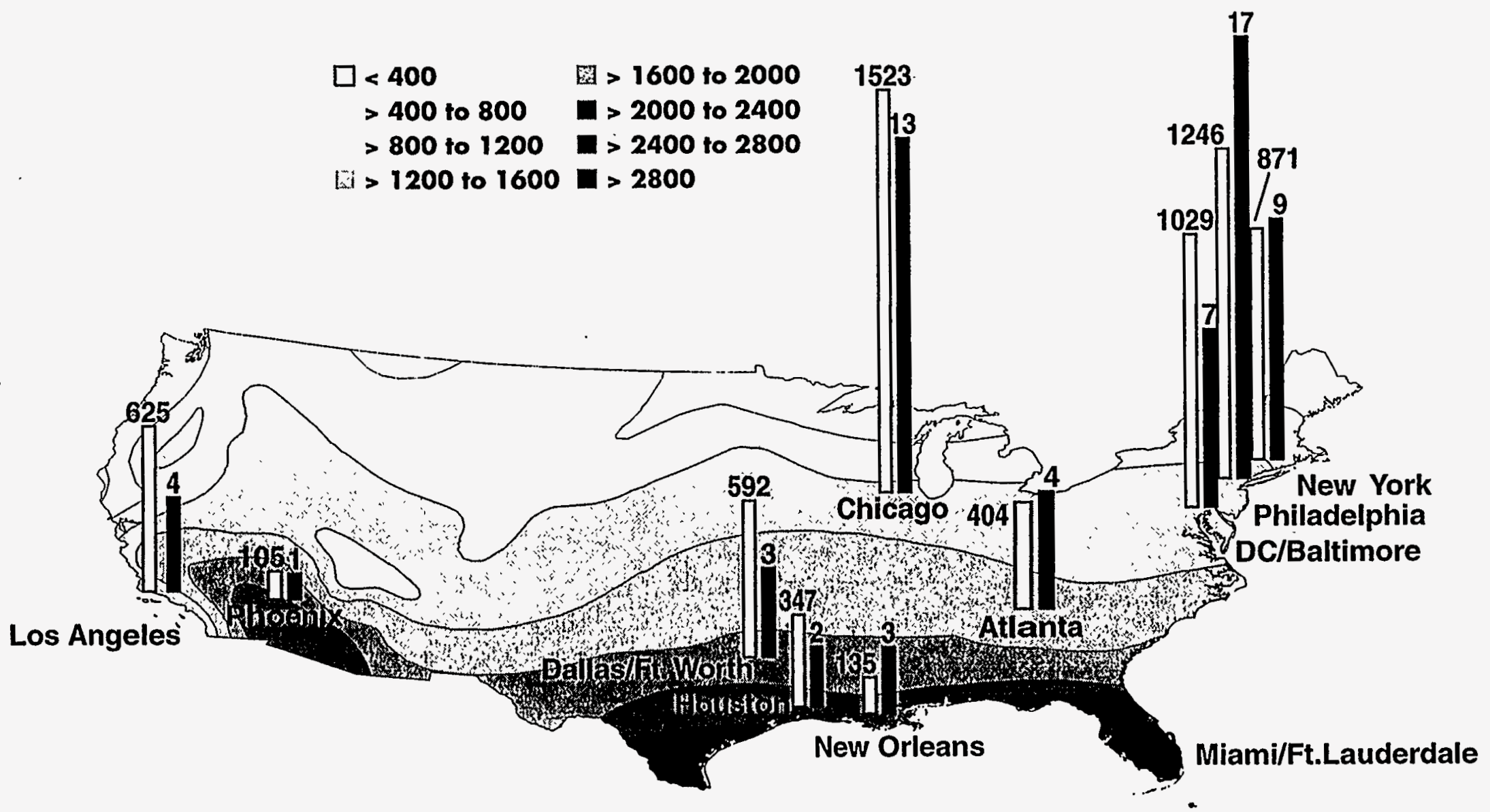

$\square$ Metropolitan-scale penalties (GBtu)

Metropolitan-scale penalty per $1000 \mathrm{ft}^{2}$ of roof area of air-conditioned buildings (Therms) 


\section{Figure EX-4: Peak-Cooling Electricity Demand Savings for 11 Metropolitan Areas}

The confour map shows simulated annual cooling hours for a typical house (Source: Kelly \& Parken 1978).

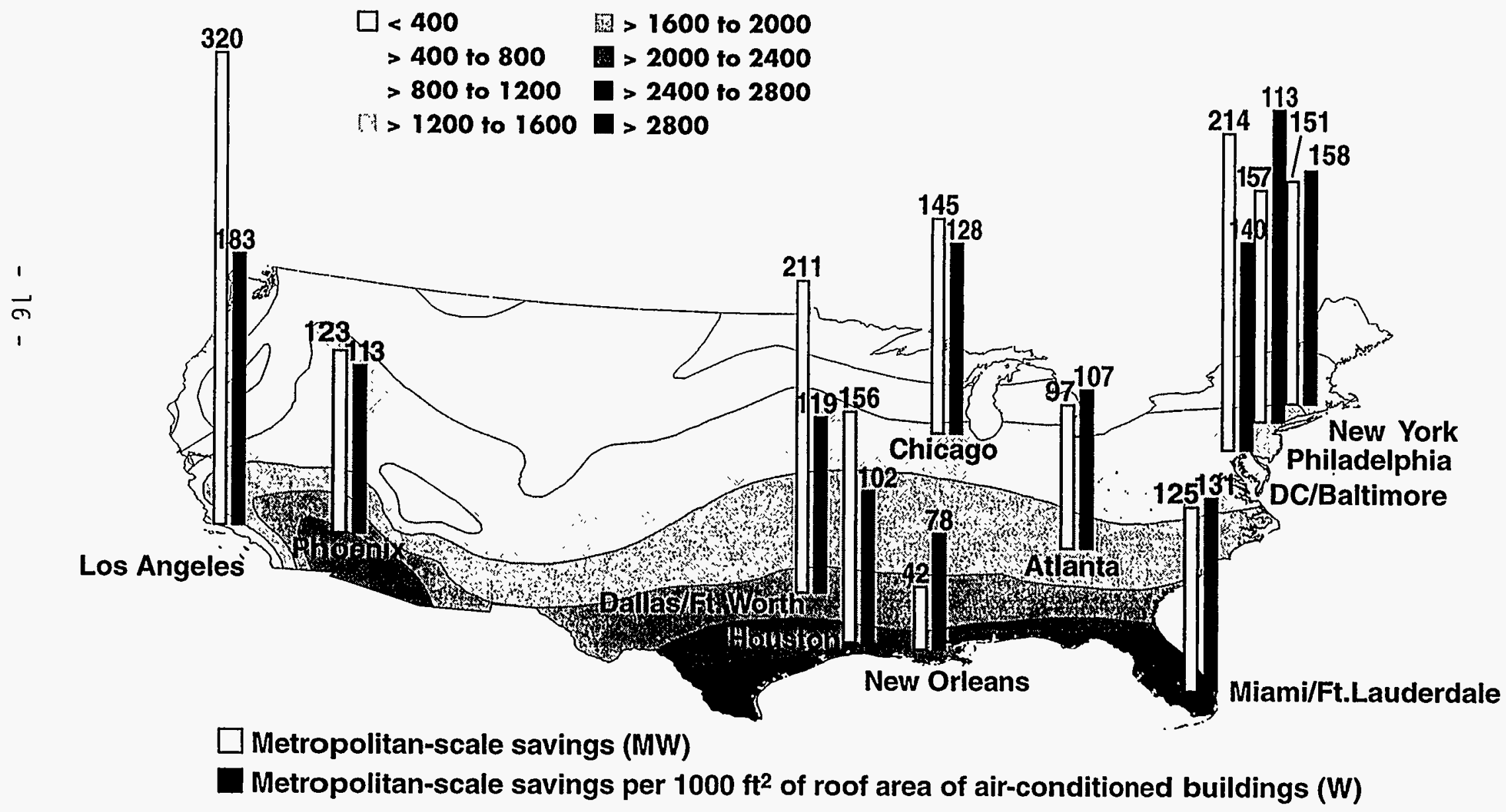




\section{Chapter 1}

\section{Introduction}

\section{Background}

The heat gain through a roof is a dominant component of the total cooling load of a single-story building. Roof loads are maximized when little or no insulation is present and the exterior surface is dark colored; i.e., when solar reflectance (albedo ${ }^{1}$ ) is low. Typically, rooftops in the United States are dark colored and in some areas roofs have little or no insulation. Thus, the potential exists for saving cooling energy, especially in hot and sunny climates. This concept is well known, as light-colored (high-albedo) roofing has historically been employed as a method to cool buildings naturally and increase human comfort in hot and sunny climates throughout the world. Sometimes a heating penalty is assessed when reflective roofing is applied, since less sunlight is absorbed by the roof during the heating season. However, in many locations and buildings the savings in cooling electricity dollars far exceed the penalty in heating gas dollars. The technology has been shown to be cost-effective, with less than a $1 \%$ additional cost when considering black versus white asphalt shingles or gravel (Bretz, et al., 1997).

The reflective-roofing strategy has been investigated through metering and simulations as a method to reduce electricity use in buildings, and decrease air temperature and air pollution in urban heat islands ${ }^{2}$. Electricity savings have been measured in several buildings in Sacramento, California (Akbari, et al., 1993a), where high-albedo coatings were applied to roofs. The reduction in cooling peak power was $30-40 \%$ and in cooling energy 40-50\%. Daily air-conditioning electricity savings of $10-43 \%$ and utility coincident peak power saving of $12-38 \%$ were demonstrated with reflective-roof coatings in field tests of eight Florida homes (Parker, et al., 1995). The largest savings were found in a building without roof insulation and the least in one with R-19 insulation. Cooling electricity savings of $22 \%$ were measured in a Mississippi office building following the application of a light-colored roof coating (Boutwell, et al., 1986). Building energy simulations completed for the Los Angeles Basin (Taha, et al., 1996) show peak cooling demand savings of $20 \%-40 \%$ in residences and $5 \%-10 \%$ in offices resulting from an increase in roof albedo of 0.4 .

\section{Objective}

The objective of this project was to develop a database. In which, we quantify building-scale and metropolitan-scale energy and monetary savings resulting from the application of light-colored roofing for several building types in 11 U.S. Metropolitan Statistical Areas (MSAs) with

\footnotetext{
' Albedo is defined as the hemispherical reflectivity integrated over the solar spectrum.

${ }^{2}$ An urban heat island is defined as a large metropolitan area with an air temperature several degrees higher than the surrounding rural environment. A discussion of current urban heat island research can be found in Rosenfeld, et al., 1995.
} 
significant heat island related problems; i.e., growing pollution, temperature, and electricity demand. The areas selected were: Atlanta, Chicago, Los Angeles, Dallas/Fort Worth, Houston, Miami/Fort Lauderdale, New Orleans, New York City, Philadelphia, Phoenix, and Washington DC/Baltimore. The buildings selected were: single-family residence (old and new), office (old and new), retail store (old and new), school (primary and secondary), health (hospital and nursing home), and grocery store. The domains of the 11 MSAs were defined by the U.S. Office and Management and Budget as either a Consolidated Metropolitan Statistical Area (CMSA) or Metropolitan Statistical Area (MSA). The 1990 population of each of these areas are listed in Table 1-1, which total almost 70 million or $28 \%$ of the entire U.S. population.

Table 1-1. 1990 populations of U.S. Consolidated Metropolitan Statistical Areas (CMSA) and Metropolitan Statistical Areas (MSA) for 11 urban heat island locations (Census, 1990). A CMSA is a collection of adjacent MSAs.

\begin{tabular}{|l||r|r|}
\hline metropolitan statistical area & designation & \multicolumn{1}{c|}{ population } \\
\hline \hline Atlanta & MSA & $2,833,511$ \\
Chicago & CMSA & $8,065,633$ \\
Los Angeles & CMSA & $14,531,529$ \\
Dallas/Fort Worth & CMSA & $3,885,415$ \\
Houston & CMSA & $3,711,043$ \\
Miami/Fort Lauderdale & CMSA & $3,192,582$ \\
New Orleans & MSA & $1,238,816$ \\
New York & CMSA & $18,087,251$ \\
Philadelphia & CMSA & $5,899,345$ \\
Phoenix & MSA & $2,122,101$ \\
DC/Baltimore & CMSA & $6,305,746$ \\
\hline \hline Total & & $69,872,972$ \\
\hline \hline United States & & $248,709,873$ \\
\hline
\end{tabular}

\section{Methodology}

The methodology used in obtaining these savings estimates is shown in Figure 1-1 and is highlighted here. The average roof albedos for existing residential and commercial buildings were estimated from an analysis of digitized aerial photographs as described in Chapter 2, and in greater detail in Appendix A. These values were used to define roof albedo in building input files for DOE-2 energy-use simulations and to adjust the metropolitan-scale estimates for local variations in albedo. 
Building-scale cooling and heating estimates resulted from using the DOE-2.1E building energy simulation program and are discussed in Chapter 3. Annual and peak electricity demand, and annual natural gas use were estimated for two roof albedo cases, 'base' and 'modified', for each building type and location. The average local price of electricity and gas were used to obtain building-scale net energy bill estimates. Building-scale energy savings were taken as the difference between the modified case and the base case. The entire building-scale data base and supplemental data are located in Appendix $B$.

Conditioned flat roof area was estimated for both residential and commercial buildings. Residential building stock were obtained from the American Housing Survey (AHS) and commercial stock from the Commercial Building Energy Consumption Survey (CBECS). These data, shown in Appendix $C$, were analyzed as described in Chapter 4 to determine residential and commercial conditioned flat roof area. The estimates were used to scale building-scale energy and monetary savings to the metropolitan-scale domain.

Metropolitan-scale HVAC annual electricity and net energy savings, peak electricity demand savings, and annual natural gas deficit were estimated, as discussed in Chapter 5, as the product of the conditioned flat roof area, the building-scale energy and monetary savings, and the local variation in base roof albedo. The entire metropolitan-scale data base and supplemental data are located in Appendix $D$. Also, the base use and savings were extrapolated to obtain national estimates. 


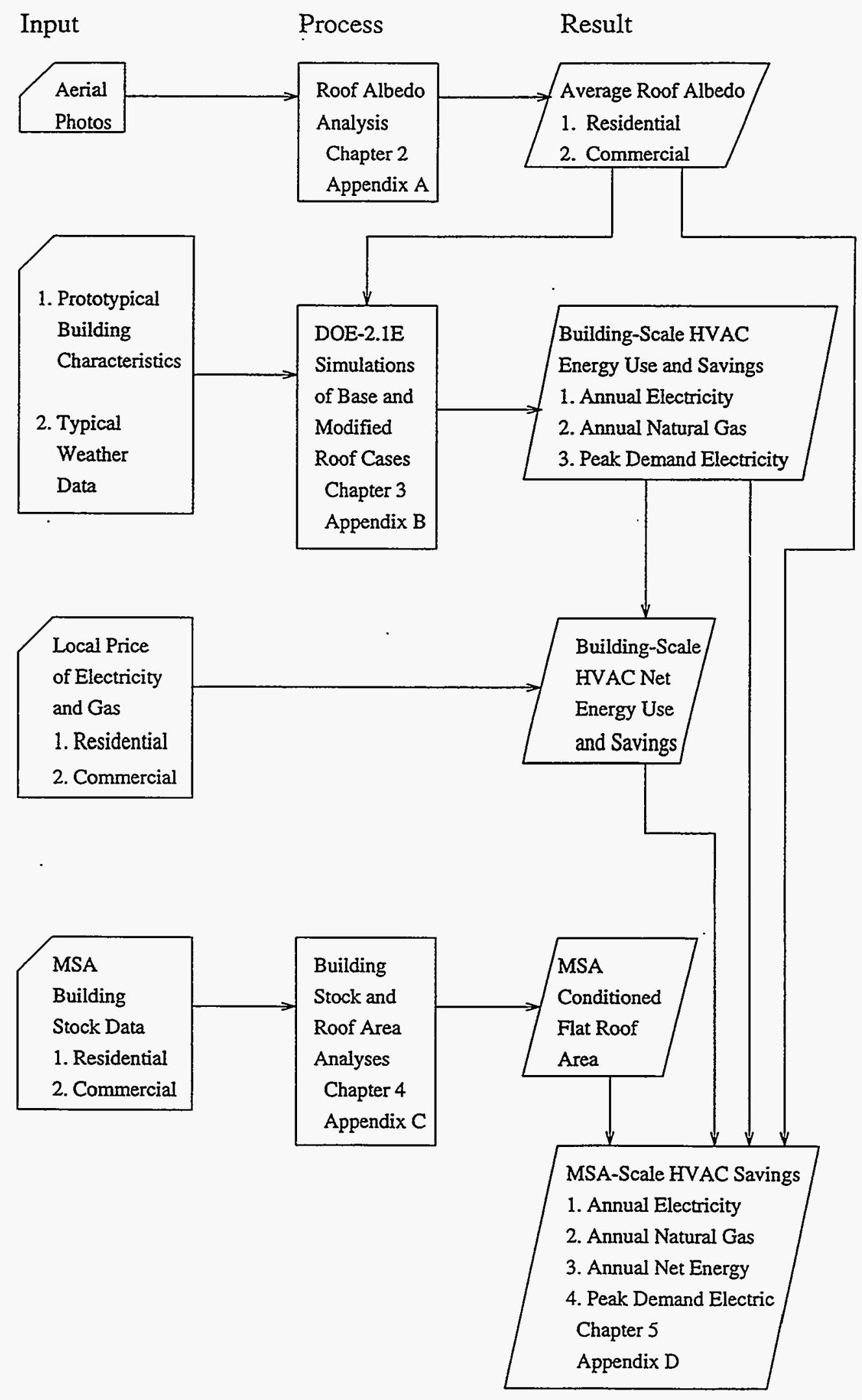

Figure 1-1. Methodology to obtain building and metropolitan-scale energy savings. 


\section{Chapter 2}

\section{Roof Albedo}

We used digitized aerial photographs to determine the average roof albedo for existing residential and commercial buildings. The average metropolitan-scale roof albedo was used to define roof albedo in building input files for DOE-2 energy-use simulations (Chapter 3), and to adjust the metropolitan-scale results for local variations in albedo (Chapter 5). The analysis and results are discussed briefly here and in greater detail in Appendix $A$.

Base case roof albedos were estimated for residential and commercial buildings from digitized photographs taken over Atlanta, Philadelphia, and Washington DC (photographs of the other areas were unavailable). The analysis of the photographs revealed that the average residential and commercial building rooftop albedos were within 0.02 (scale $0-1$ ) of each other, and that rooftops were lightest in Atlanta and darkest in Philadelphia; i.e., roofs get darker moving south to north. As shown in Table 2-1, the average albedo of all buildings was 0.31 in Atlanta, 0.25 in Washington DC, and 0.19 in Philadelphia. The average for all buildings and locations was 0.25 , which was the value used as input to building energy simulation models. We consider the value 0.25 high and think it should be closer to 0.15 , since a typical new black asphalt shingle has a measured albedo of 0.05, dark brown 0.08, green 0.19, and white of 0.25 (Berdahl and Bretz, 1995).

The values in Table 2-1 were defined as the local base albedo and were used to adjust for local variations, where the base albedo was not 0.25 , as they were in the building energy simulations. This is an application of the observation that energy and monetary savings follow a linear relationship with changes in roof albedo. We assumed all Southern locations (Los Angeles, Dallas/Fort Worth, Houston, Miami/Fort Lauderdale, New Orleans, and Phoenix) had the same albedo as Atlanta. Likewise, we assumed the Northern locations of Chicago and New York City had the same albedo as Philadelphia.

Table 2-1. Average roof albedo for existing residential and commercial buildings from analysis of digitized aerial photographs taken over Atlanta, Washington DC, and Philadelphia.

\begin{tabular}{|l||c|c|c|}
\hline \multirow{2}{*}{ metropolitan area } & \multicolumn{3}{c|}{ average roof albedo } \\
\cline { 2 - 4 } & residential & commercial & total \\
\hline \hline Atlanta & 0.30 & 0.32 & 0.31 \\
Washington DC & 0.25 & 0.25 & 0.25 \\
Philadelphia & 0.20 & 0.18 & 0.19 \\
\hline average & 0.25 & 0.25 & 0.25 \\
\hline
\end{tabular}




\section{Chapter 3}

\section{Building-Scale HVAC Energy and Monetary Base Use and Savings}

Building-scale HVAC electricity and natural gas use were estimated using the DOE-2.1E building energy simulation program (BESG, 1990). DOE-2 requires 'typical' annual hourly weather data for each location and prototypical building characteristics as input. The weather tapes that represented each MSA are shown in Table B-1 with typical weather data.

\section{DOE-2 Building Prototypes}

Prototypical building characteristics were developed from construction, internal load, and HVAC system characteristics summarized in Table 3-1 and described in detail in Tables B-3 through B-18 for single-family residential and commercial types (office, retail store, primary and secondary schools, hospital, nursing home, and grocery store) types. The residential, office, and retail store buildings were split into old (pre-1980) and new (1980 and later) vintages and modeled with both gas furnaces and electric heat pumps.

The HVAC system components (supply fan, packaged air conditioner / heat pump, and gas furnace; chiller, cooling tower, and boiler for hospital) were sized by allowing DOE-2 to select base case default capacities for each building type and location. Component sizes were then selected based on engineering judgement and used in the building prototypes for DOE-2 modeling in both the base and modified roof cases, and are displayed in Tables B-3 through B-18. In some cases, it was found that light-colored roofing may allow for the air conditioner to be down-sized.

\section{Roof/Attic/Ceiling Model}

The roof/attic/ceiling structure is difficult to model in DOE-2, because it is an unconditioned space with significant thermal mass, experiences high temperature swings, and is prone to irregular ventilation rates. It can be modeled as a single-layered construction or as an unconditioned zone. The single-layered construction model has the benefit of incorporating the insulation thermal mass, where the unconditioned zone model can account for variation in attic ventilation rates. However, the effective thermal resistance of a naturally ventilated attic can be modeled as constant (ASHRAE, 1989). Also, regarding the single-layered model, errors are significant only in very poorly insulated or power-ventilated attics (Huang, et al., 1987). We chose the singlelayered construction model, since we were interested to include the insulation thermal mass, and our buildings were fitted with either R-11 or R-19 insulation and did not have power ventilation.

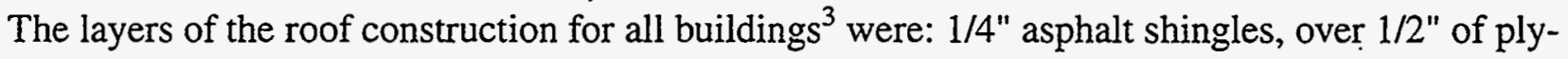
wood, over an effective attic resistance, over insulation (R-11 for old vintages or R-19 for new), over 1/2" of drywall. The roof exterior had an infrared emittance of 0.91 and either a base

\footnotetext{
${ }^{3}$ The exception was the hospital, which also had a concrete deck.
} 
Table 3-1. Prototypical building HVAC system and construction characteristics.

\begin{tabular}{|c|c|c|c|c|c|c|c|}
\hline \multirow{2}{*}{\multicolumn{2}{|c|}{ Building Prototype }} & \multirow{3}{*}{$\begin{array}{c}\text { HVAC }^{\mathrm{a}} \\
\text { System Type }\end{array}$} & \multicolumn{2}{|c|}{ Insulation } & \multirow{4}{*}{$\begin{array}{c}\begin{array}{c}\text { Floor Area } \\
\left(\mathbf{f t}^{2}\right)\end{array} \\
1500\end{array}$} & \multirow{4}{*}{$\begin{array}{c}\text { Floors } \\
1\end{array}$} & \multirow{4}{*}{$\begin{array}{c}\begin{array}{c}\text { Flat Roof } \\
\text { Area }^{\mathbf{b}}\left(\mathbf{f t}^{2}\right)\end{array} \\
1500\end{array}$} \\
\hline & & & \multirow{2}{*}{$\begin{array}{l}\text { Roof } \\
\text { R-11 }\end{array}$} & \multirow{2}{*}{$\frac{\text { Wall }}{\mathrm{R}-7}$} & & & \\
\hline \multirow{2}{*}{ Residence } & Old & & & & & & \\
\hline & New & Gas Furnace \& Heat Pump & $\mathrm{R}-19$ & $\mathrm{R}-11$ & & & \\
\hline \multirow{2}{*}{ Office } & Old & Gas Furnace \& Heat Pump & $\mathrm{R}-11$ & $R: 7$ & \multirow{2}{*}{4900} & \multirow{2}{*}{1} & \multirow{2}{*}{4900} \\
\hline & New & Gas Furnace \& Heat Pump & R-19 & R-11 & & & \\
\hline \multirow{2}{*}{ Retail Store } & Old & Gas Furnace \& Heat Pump & $\mathrm{R}-11$ & $\mathrm{R}-7$ & \multirow{2}{*}{8100} & \multirow{2}{*}{1} & \multirow{2}{*}{8100} \\
\hline & New & Gas Furnace \& Heat Pump & $\mathrm{R}-19$ & R-11 & & & \\
\hline \multirow{2}{*}{ School } & Primary & \multirow{2}{*}{ Gas Furnace } & \multirow{2}{*}{ R-11 } & \multirow{2}{*}{ R-7 } & 35000 & 1 & 35000 \\
\hline & Secondary & & & & 100000 & 3 & 57000 \\
\hline \multirow{2}{*}{ Health } & Hospital & Gas Boiler & \multirow{2}{*}{ R-11 } & \multirow{2}{*}{$\mathrm{R}-7$} & 132000 & 7 & 18900 \\
\hline & Nursing Home & Gas Furnace & & & 38400 & 1 & 38400 \\
\hline Grocery Store & & Gas Furnace & R-11 & R-7 & 4400 & 1 & 4400 \\
\hline
\end{tabular}

a All air-conditioning systems were of the packaged-single-zone air-cooled type, except for the Hospital which was modeled with a chiller and cooling tower.

b The residential sloped roof area was $1722 \mathrm{ft}^{2}$. The commercial roofs were flat. 
or modified albedo, as described below. The residential roof was modeled with a two-piece sloped $\left(20^{\circ}\right)$ construction and the commercial as a flat single-piece construction.

DOE-2 building energy simulations were completed for each building type and location for two cases: base roof albedo and modified. The base case was applied to both residences and commercial buildings, which was determined to be 0.25 from analysis of aerial photographs, as discussed in Chapter 2 and Appendix A. It was defined as the average albedo of the surveyed roof population, a distribution of dark and light roofs.

The modified roof albedo case was based on laboratory tested light-colored roofing materials, which differed for low-slope residential and flat-roof commercial applications. Several recently developed white roof coatings for low-slope residential application have measured albedos of 0.51-0.58, see Attachment 1. White polymer roof coatings for flat-roof commercial applications are available in the market with a fresh, clean albedo of 0.79 , dirty of $0.59-0.61$, and washed of 0.64-0.76 (Bretz and Akbari, 1994). Based on these data the modified roof albedos selected were 0.55 for low-sloped residential and 0.70 for flat-roof commercial buildings. Therefore, changes in roof albedo were 0.30 for residences and 0.45 for commercial buildings.

\section{Electricity and Gas Prices}

The Energy Information Agency (EIA) was the source for residential and commercial energy prices. These were the average 1993 price of electricity (EIA, 1993a) for each utility serving its respective metropolitan area and the state-wide average price of natural gas (EIA, 1993b). They were used to calculate the annual price of energy paid by each building in each metropolitan area and are shown in Table B-2. Note, peak demand was not included in the price of electricity.

\section{DOE-2 Simulated HVAC Electricity, Natural Gas, and Net Energy Base Use}

Examples of DOE-2 simulated HVAC annual electricity, natural gas, net energy, and peak demand for the base case are presented in Table 3-2 for residential, office, and retail store buildings in the Los Angeles, Miami, and Phoenix MSAs. DOE- 2 results for all building types and MSAs are presented in Table B-19. The building peak demand was non-coincident with local utility demand, and the time it occurred varied by building, location, and roof albedo. The net energy dollars for the base and modified cases for both fuel types are shown in Table 3-3. The table illustrates the relatively large impact on electricity dollar savings compared to gas deficit dollars.

\section{DOE-2 Simulated HVAC Electricity, Natural Gas, and Net Energy Savings}

DOE-2 simulated HVAC energy and monetary savings were calculated as the difference between the modified case relative to the base. Examples are presented in Table 3-2, per $1000 \mathrm{ft}^{2}$ flat roof area, and for all buildings and locations in Table B-19. The savings were applicable to singlestory buildings or the top floor of multi-story buildings, since only the top floor would realize the benefit of a reduced cooling load. 
Table 3-2(a). DOE-2 simulated HVAC base use and savings from light-colored roofing for single-story residences; annual electricity and net energy, peak electricity demand, and annual natural gas are estimated per $1000 \mathrm{ft}^{2}$ of flat roof area.

\begin{tabular}{|c|c|c|c|c|c|c|c|c|c|c|c|c|}
\hline \multicolumn{13}{|c|}{ single-story residential } \\
\hline \multirow{3}{*}{ Metropolitan Area } & \multicolumn{3}{|c|}{ Old w/ Gas Furnace } & \multicolumn{3}{|c|}{ Old w/ Heat Pump } & \multicolumn{3}{|c|}{ New w/ Gas Furnace } & \multicolumn{3}{|c|}{ New w/ Heat Pump } \\
\hline & \multirow{2}{*}{$\begin{array}{l}\text { Base } \\
\text { Case }\end{array}$} & \multicolumn{2}{|c|}{ Savings } & \multirow{2}{*}{$\begin{array}{l}\text { Base } \\
\text { Case }\end{array}$} & \multicolumn{2}{|c|}{ Savings } & \multirow{2}{*}{$\begin{array}{l}\text { Base } \\
\text { Case }\end{array}$} & \multicolumn{2}{|c|}{ Savings } & \multirow{2}{*}{$\begin{array}{l}\text { Base } \\
\text { Case } \\
\end{array}$} & \multicolumn{2}{|c|}{ Savings } \\
\hline & & $\Delta$ & $\%$ & & $\Delta$ & $\%$ & & $\Delta$ & $\%$ & & $\Delta$ & $\%$ \\
\hline Los Angeles & & & & & & & & & & & & \\
\hline Electricity $\left(\mathrm{kWh} / 1000 \mathrm{ft}^{2}\right)$ & 1364 & 238 & 17 & 2588 & 177 & 7 & 846 & 126 & 15 & 1349 & 101 & 7 \\
\hline Gas (kBtu/1000ft $\left.{ }^{2}\right)$ & 10721 & -544 & -5 & 0 & 0 & 0 & 5375 & -244 & -5 & 0 & 0 & 0 \\
\hline Net Energy $\left(\$ / 1000 \mathrm{ft}^{2}\right)$ & 200 & 20 & 10 & 254 & 18 & 7 & 116 & 11 & 9 & 132 & 10 & 8 \\
\hline Peak (W/1000 ft $\left.{ }^{2}\right)$ & 2305 & 247 & 11 & 2305 & 247 & 11 & 1481 & 130 & 9 & 1481 & 130 & 9 \\
\hline Miami & & & & & & & & & & & & \\
\hline Electricity $\left(\mathrm{kWh} / 1000 \mathrm{ft}^{2}\right)$ & 5150 & 376 & 7 & 5277 & 374 & 7 & 3689 & 205 & 6 & 3734 & 205 & 5 \\
\hline Gas $\left(\mathrm{kBtu} / 1000 \mathrm{ft}^{2}\right)$ & 1086 & -20 & -2 & 0 & 0 & 0 & 457 & -1 & 0 & 0 & 0 & 0 \\
\hline Net Energy $\left(\$ / 1000 \mathrm{ft}^{2}\right)$ & 428 & 30 & 7 & 427 & 30 & 7 & 303 & 16 & 5 & 303 & 17 & 6 \\
\hline Peak $\left(W / 1000 f^{2}\right)$ & 2409 & 208 & 9 & 2409 & 208 & 9 & 1545 & 84 & 5 & 1545 & 84 & 5 \\
\hline Phoenix & & & & & & & & & & & & \\
\hline Electricity $\left(\mathrm{kWh} / 1000 \mathrm{ft}^{2}\right)$ & 5495 & 484 & 9 & 6643 & 459 & 7 & 3590 & 256 & 7 & 4102 & 247 & 6 \\
\hline Gas $\left(k B t u / 1000 f^{2}\right)$ & 9388 & -211 & -2 & 0 & 0 & 0 & 4816 & -90 & -2 & 0 & 0 & 0 \\
\hline Net Energy $\left(\$ / 1000 \mathrm{ft}^{2}\right)$ & 656 & 51 & 8 & 711 & 49 & 7 & 419 & 27 & 6 & 439 & 27 & 6 \\
\hline Peak (W/1000ft $\left.{ }^{2}\right)$ & 4123 & 162 & 4. & 4123 & 162 & 4 & 2656 & 97 & 4 & 2656 & 97 & 4 \\
\hline
\end{tabular}


Table 3-2(b). DOE-2 simulated HVAC base use and savings from light-colored roofing for single-story offices; annual electricity and net energy, peak electricity demand, and annual natural gas are estimated per $1000 \mathrm{ft}^{2}$ of flat roof area.

\begin{tabular}{|c|c|c|c|c|c|c|c|c|c|c|c|c|}
\hline \multicolumn{13}{|c|}{ single-story office } \\
\hline \multirow{3}{*}{ Metropolitan Area } & \multicolumn{3}{|c|}{ Old w/ Gas Furnace } & \multicolumn{3}{|c|}{ Old w/ Heat Pump } & \multicolumn{3}{|c|}{ New w/ Gas Furnace } & \multicolumn{3}{|c|}{ New w/ Heat Pump } \\
\hline & \multirow{2}{*}{$\begin{array}{l}\text { Base } \\
\text { Case } \\
\end{array}$} & \multicolumn{2}{|c|}{ Savings } & \multirow{2}{*}{$\begin{array}{l}\text { Base } \\
\text { Case } \\
\end{array}$} & \multicolumn{2}{|c|}{ Savings } & \multirow{2}{*}{$\begin{array}{l}\text { Base } \\
\text { Case } \\
\end{array}$} & \multicolumn{2}{|c|}{ Savings } & \multirow{2}{*}{$\begin{array}{l}\text { Base } \\
\text { Case } \\
\end{array}$} & \multicolumn{2}{|c|}{ Savings } \\
\hline & & $\Delta$ & $\%$ & & $\Delta$ & $\%$ & & $\Delta$ & $\%$ & & $\Delta$ & $\%$ \\
\hline \multicolumn{13}{|l|}{ Los Angeles } \\
\hline Electricity $\left(\mathrm{kWh} / 1000 \mathrm{ft}^{2}\right)$ & 4174 & 377 & 9 & 4293 & 341 & 8 & 3271 & 221 & 7 & 3301 & 215 & 7 \\
\hline Natural Gas $\left(\mathrm{kBtu} / 1000 \mathrm{ft}^{2}\right)$ & 878 & -306 & -35 & 0 & 0 & 0 & 224 & -82 & -37 & 0 & 0 & 0 \\
\hline Net Energy $\left(\$ / 1000 \mathbf{f t}^{2}\right)$ & 377 & 32 & 8 & 382 & 30 & 8 & 292 & 19 & 7 & 294 & 19 & 6 \\
\hline Peak $\left(W / 1000 f^{2}\right)$ & 3914 & 292 & 7 & 3914 & 292 & 7 & 2886 & 173 & 6 & 2886 & 173 & 6 \\
\hline \multicolumn{13}{|l|}{ Miami } \\
\hline Electricity $\left(\mathrm{kWh} / 1000 \mathrm{ft}^{2}\right)$ & 8664 & 424 & 5 & 8670 & 418 & 5 & 6536 & 239 & 4 & 6536 & 233 & 4 \\
\hline Natural Gas $\left(\mathrm{kBtu} / 1000 \mathrm{ft}^{2}\right)$ & 61 & 0 & 0 & 0 & 0 & 0 & 0 & 0 & 0 & 0 & 0 & 0 \\
\hline Net Energy $\left(\$ / 1000 \mathrm{ft}^{2}\right)$ & 590 & 29 & 5 & 590 & 28 & 5 & 444 & 16 & 4 & 444 & 16 & 4 \\
\hline Peak $\left(W / 1000 f^{2}\right)$ & 4482 & 153 & 3 & 4482 & 153 & 3 & 3208 & 57 & 2 & 3208 & 57 & 2 \\
\hline \multicolumn{13}{|l|}{ Phoenix } \\
\hline Electricity $\left(\mathrm{kWh} / 1000 \mathrm{ft}^{2}\right)$ & 8030 & 562 & 7 & 8192 & 538 & 7 & 5848 & 305 & 5 & 5890 & 293 & 5 \\
\hline Natural Gas $\left(\mathrm{kBtu} / 1000 \mathrm{ft}^{2}\right)$ & 1000 & -265 & -26 & 0 & 0 & 0 & 286 & -82 & -29 & 0 & 0 & 0 \\
\hline Net Energy $\left(\$ / 1000 \mathrm{ft}^{2}\right)$ & 744 & 50 & 7 & 754 & 50 & 7 & 539 & 28 & 5 & 542 & 27 & 5 \\
\hline Peak $\left(W / 1000 f^{2}\right)$ & 5857 & 196 & 3 & 5857 & 196 & 3 & 4065 & 96 & 2 & 4065 & 96 & 2 \\
\hline
\end{tabular}


Table 3-2(c). DOE-2 simulated HVAC base use and savings from light-colored roofing for single-story retail stores; annual electricity and net energy, peak electricity demand, and annual natural gas are estimated per $1000 \mathrm{ft}^{2}$ of flat roof area.

\begin{tabular}{|c|c|c|c|c|c|c|c|c|c|c|c|c|}
\hline \multicolumn{13}{|c|}{ single-story retail store } \\
\hline \multirow{3}{*}{ Metropolitan Area } & \multicolumn{3}{|c|}{ Old w/ Gas Furnace } & \multicolumn{3}{|c|}{ Old w/ Heat Pump } & \multicolumn{3}{|c|}{ New w/ Gas Furnace } & \multicolumn{3}{|c|}{ New w/ Heat Pump } \\
\hline & \multirow{2}{*}{$\begin{array}{l}\text { Base } \\
\text { Case } \\
\end{array}$} & \multicolumn{2}{|c|}{ Savings } & \multirow{2}{*}{$\begin{array}{l}\text { Base } \\
\text { Case } \\
\end{array}$} & \multicolumn{2}{|c|}{ Savings } & \multirow{2}{*}{$\begin{array}{l}\text { Base } \\
\text { Case } \\
\end{array}$} & \multicolumn{2}{|c|}{ Savings } & \multirow{2}{*}{$\begin{array}{l}\text { Base } \\
\text { Case } \\
\end{array}$} & \multicolumn{2}{|c|}{ Savings } \\
\hline & & $\Delta$ & $\%$ & & $\Delta$ & $\%$ & & $\Delta$ & $\%$ & & $\Delta$ & $\%$ \\
\hline Los Angeles & & & & & & & & & & & & \\
\hline Electricity $\left(\mathrm{kWh} / 1000 \mathrm{ft}^{2}\right)$ & 6026 & 593 & 10 & 6026 & 593 & 10 & 4760 & 344 & 7 & 4760 & 344 & 7 \\
\hline Natural Gas $\left(\mathrm{kBtu} / 1000 \mathrm{ft}^{2}\right)$ & 864 & 0 & 0 & 0 & 0 & 0 & 864 & 0 & 0 & 0 & 0 & 0 \\
\hline Net Energy $\left(\$ / 1000 \mathrm{ft}^{2}\right)$ & 541 & 53 & 10 & 536 & 53 & 10 & 429 & 31 & 7 & 424 & 31 & 7 \\
\hline Peak $\left(W / 1000 \mathrm{ft}^{2}\right)$ & 3352 & 193 & 6 & 3352 & 193 & 6 & 2264 & 38 & 2 & 2264 & 38 & 2 \\
\hline Miami & & & & & & & & & & & & \\
\hline Electricity $\left(\mathrm{kWh} / 1000 \mathrm{ft}^{2}\right)$ & 10443 & 477 & 5 & 10443 & 477 & 5 & 7839 & 260 & 3 & 7839 & 260 & 3 \\
\hline Natural Gas $\left(\mathrm{kBtu} / 1000 \mathrm{ft}^{2}\right)$ & 864 & 0 & 0 & 0 & 0 & 0 & 864 & 0 & 0 & 0 & 0 & 0 \\
\hline Net Energy $\left(\$ / 1000 \mathrm{ft}^{2}\right)$ & 715 & 32 & 4 & 710 & 32 & 5 & 538 & 18 & 3 & 533 & 18 & 3 \\
\hline Peak (W/1000ft $\left.{ }^{2}\right)$ & 3270 & 131 & 4 & 3270 & 131 & 4 & 2374 & 70 & 3 & 2374 & 70 & 3 \\
\hline Phoenix & & & & & & & & & & & & \\
\hline Electricity $\left(\mathrm{kWh} / 1000 \mathrm{ft}^{2}\right)$ & 10497 & 716 & 7 & 10497 & 716 & 7 & 7567 & 416 & 5 & 7567 & 416 & 5 \\
\hline Natural Gas $\left(\mathrm{kBtu} / 1000 \mathrm{ft}^{2}\right)$ & 864 & 0 & 0 & 0 & 0 & 0 & 864 & 0 & 0 & 0 & 0 & 0 \\
\hline Net Energy $\left(\$ / 1000 \mathbf{f t}^{2}\right)$ & 970 & 66 & 7 & 966 & 66 & 7 & 701 & 38 & 5 & 696 & 38 & 5 \\
\hline Peak $\left(W / 1000 \mathrm{ft}^{2}\right)$ & 4748 & 112 & 2 & 4748 & 112 & 2 & 3219 & 91 & 3 & 3219 & 91 & 3 \\
\hline
\end{tabular}


Table 3-3. DOE-2 simulated HVAC base and modified case annual energy cost estimates for single-story buildings modeled with gas furnace heating expressed in dollars per $1000 \mathrm{ft}^{2}$ of flat roof area.

\begin{tabular}{|c|c|c|c|c|c|c|c|c|}
\hline \multirow{2}{*}{ metropolitan area } & \multirow{2}{*}{ roof color } & \multirow{2}{*}{ type } & \multicolumn{2}{|c|}{ residence } & \multicolumn{2}{|c|}{ office } & \multicolumn{2}{|c|}{ retail store } \\
\hline & & & old & new & old & new & old & new \\
\hline \multirow{4}{*}{ Los Angeles } & \multirow{2}{*}{ dark (base) } & electricity & 134 & 83 & 371 & 291 & 536 & 424 \\
\hline & & natural gas & 66 & 33 & 5 & 1 & 5 & 5 \\
\hline & \multirow{2}{*}{ light (modified) } & electricity & 110 & 71 & 338 & 271 & 484 & 393 \\
\hline & & natural gas & 70 & 35 & 7 & 2 & 5 & 5 \\
\hline \multirow{4}{*}{ Miami } & \multirow{2}{*}{ dark (base) } & electricity & 417 & 299 & 589 & 444 & 710 & 533 \\
\hline & & natural gas & 11 & 5 & 0 & 0 & 5 & 5 \\
\hline & \multirow{2}{*}{ light (modified) } & electricity & 387 & 282 & 560 & 428 & 678 & 515 \\
\hline & & natural gas & 11 & 5 & 0 & 0 & 5 & 5 \\
\hline \multirow{4}{*}{ Phoenix } & \multirow{2}{*}{ dark (base) } & electricity & 588 & 384 & 739 & 538 & 966 & 696 \\
\hline & & natural gas & 68 & 34 & 5 & 1 & 4 & 4 \\
\hline & \multirow{2}{*}{ light (modified) } & electricity & 536 & 356 & 687 & 510 & 900 & 658 \\
\hline & & natural gas & 69 & 35 & 7 & 2 & 4 & 4 \\
\hline
\end{tabular}

The annual cooling electricity savings ranged from 100 to $480 \mathrm{kWh}$ per $1000 \mathrm{ft}^{2}$ of flat roof area ( 7 to $17 \%$ ) for old residential buildings, 40 to $260 \mathrm{kWh}$ per $1000 \mathrm{ft}^{2}$ of flat roof area (6 to $15 \%$ ) for new residences, 170 to $560 \mathrm{kWh}$ per $1000 \mathrm{ft}^{2}$ of flat roof area (5 to $9 \%$ ) for old offices, 100 to $310 \mathrm{kWh}$ per $1000 \mathrm{ft}^{2}$ of flat roof area ( 3 to $7 \%$ ) for new offices, 240 to $720 \mathrm{kWh}$ per $1000 \mathrm{ft}^{2}$ of flat roof area (5 to 10\%) for old retail stores, and 130 to $420 \mathrm{kWh}$ per $1000 \mathrm{ft}^{2}$ flat roof area ( 3 to $7 \%$ ) for new retail stores, all with gas furnace heating. The relative savings were most significant in the shell dominated residential prototypes, as the others were internal load dominated. These six building types accounted for $93 \%$ of the total conditioned fiat roof area of the 11 MSAs.

Prototypes with gas heating systems had annual electricity and net energy savings greater than those with electric heat pumps, because of the higher cost of electric heat relative to gas. The residential, office, and retail store old vintage prototypes had relatively greater savings than those of the new vintage, primarily because of the roof insulation R-value differential. Prototypes with longer hours of operation showed relatively larger savings with respect to those with shortened schedules. For example, the hospital and nursing home prototypes operate continuously and had the largest savings in annual electricity, which were 455 to $1687 \mathrm{kWh}$ per $1000 \mathrm{ft}^{2}$ of flat roof area ( 3 to $8 \%$ ) for the hospital and 183 to $1071 \mathrm{kWh}$ per $1000 \mathrm{ft}^{2}$ of flat roof area (5 to $11 \%$ ) for the nursing home. These were followed in order by retail stores, the grocery store, offices, residences, and schools. Peak electricity demand savings were observed in all prototypes and 
locations, however they exhibited random behavior since the system sizes were pre-set and peak loads were not always met.

The few prototypes with annual electricity and net energy deficits or savings very close to zero were found in Chicago and Philadelphia among the new vintage, electric heat pump office models, and additionally for residences in New York City. The new vintage, gas furnace heated residence for Philadelphia also operated at a net energy deficit.

\section{DOE-2 Simulated HVAC Electricity, Natural Gas, and Net Energy Savings by Climate}

We plotted HVAC electricity, net energy, and peak savings versus cooling degree hours and gas deficit versus heating degree hours to exhibit trends between these variables. These are shown in Figures B-1 through B-4 for all building types. Generally, annual electricity and net energy savings increased with cooling degree hours and natural gas deficit increased with heating degree hours. Peak electricity demand savings indicated no correlation with cooling degree hours, since the system sizes were fixed and the peak cooling demands were not always met. Figure 3-1 illustrates the relationship between increasing net energy savings and increasing cooling degree hours for old and new residences, offices, and retail stores, all with gas furnace heating. Los Angeles and Phoenix exhibit greater savings than the trend because of a high solar radiation fraction (low sky cover) relative to the other locations, see Table B-1. These trends can provide a means to determine at which locations and to what degree light-colored roofing is cost-effective.

\section{Linearity Property}

The annual electricity and net energy savings, peak electricity demand savings, and annual natural gas deficit were found to be a linear function of changes in roof albedo for each building type and location. This was observed in a previous Lawrence Berkeley National Laboratory (LBNL) research study of residential and office buildings in the Los Angeles Basin, which is documented in Attachment 2 and referred to as the 'linearity property'. Essentially, the linearity property allows for energy and monetary savings presented here to be adjusted for applications where the base and/or modified rooftop albedo differ from our assumptions. In Chapter 5 we make use of this property, since the base albedo varies with location.

The savings presented in this chapter are based on a change in albedo $(\Delta \mathrm{a})$ of 0.30 for residences and 0.45 for commercial buildings. For example, the residential savings would increase $67 \%$ if the base case were represented by a new black asphalt shingle with an albedo of 0.05 (in place of 0.25$)$ and the modified case remained at $0.55(\Delta \mathrm{a} 1=0.30$ and $\Delta \mathrm{a} 2=0.50)$. 

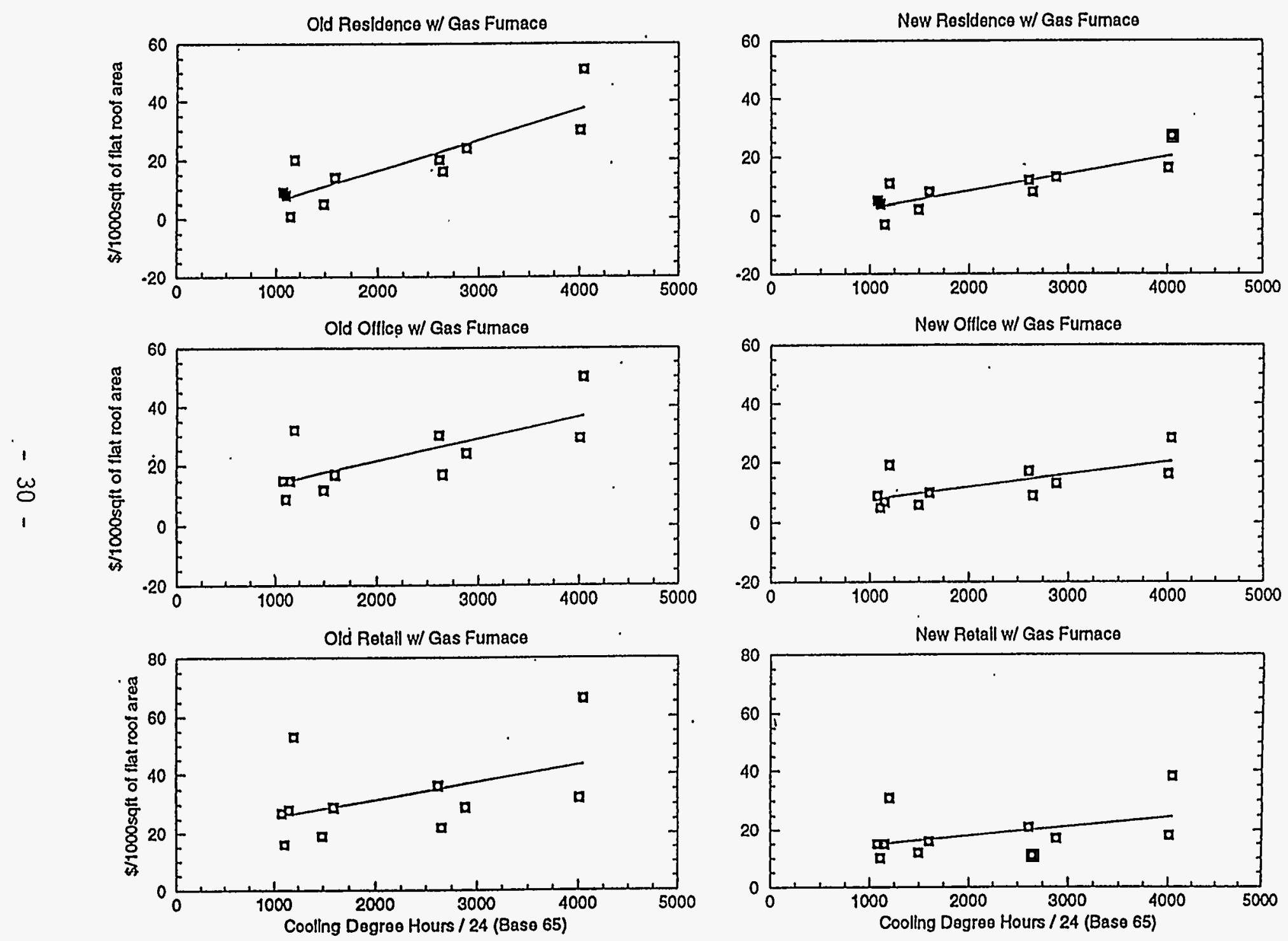

Figure 3-1. DOE-2 simulated HVAC annual net energy savings from light-colored roofing for singlestory old and new residences, offices, and retail stores, all with gas furnace heating. The figure illustrates the relationship between increasing net energy savings and increasing cooling degree hours. 


\section{Discussion}

We believe the savings predicted with DOE-2 were under-estimated for the following five reasons. First, the DOE-2 simulations do not include the recently developed LBNL roof/attic model $^{4}$ that better simulates the roof/attic heat transfer mechanism in DOE-2 (Gartland, et al., 1996). This model incorporates radiative heat transfer, an improved external convection coefficient, and insulation temperature-dependent conductivity, which collectively increase the heat transfer through the roof 5 . Second, the roof composite model does not include a framing factor, which accounts for joists, recessed cans, electrical junction boxes, access doors, and insulation voids, etc, and would increase heat transfer through the structure. Third, the roof modeling neglects the losses to the thermal distribution system in the attic, which under-predicts peak airconditioning load during summer operation. Fourth, the simulations do not include the effect of snow; i.e., high-albedo material on the roof, which renders the actual roof color irrelevant during the winter in areas with snow fall. Hence, the heating penalty estimated from a light-colored roof is currently being paid in cold and snowy areas and would incur no additional penalty. Fifth, the net energy savings estimates do not include savings in peak electricity demand charges. Another consideration is that DOE-2 does not perform thermal comfort calculations. In residences without air conditioning a light-colored roof will lower the mean radiant temperature of the roof and provide for a more comfortable indoor environment.

\footnotetext{
${ }^{4}$ The roof/attic model functioned only with single-zone buildings with single-construction flat roofs. Therefore, it could not be applied to our buildings, since the residences were modeled with two-piece sloped roofs and the commercial buildings with multiple zones.

${ }^{5}$ Gartland compared her model with measured hourly air-conditioning electricity use of a school bungalow in Sacramento, California, which initially had a brown roof and was later coated white. The model correctly predicted the annual HVAC electricity savings from the brown and white-coated roofs, which were previously under-estimated by $38-50 \%$ without the model.
} 


\section{Chapter 4}

\section{Building Stock and Roof Area}

\section{Residential}

Conditioned flat roof area was estimated for both residential and commercial buildings. Data for residential building stock came from the American Housing Survey (Source: AHS), a detailed study of housing in cities across the United States ${ }^{6}$. AHS data used were, the number of residences $(N)$, the average square footage of each residence (AREA), the average number of floors $(F L R)$, and the saturation (SAT) of natural gas heating, electric heat pumps, and central air conditioning in each MSA. These data were extracted for two vintage categories, houses built before 1980 (old) and those built from 1980 to 1990 (new), and are displayed in Tables C-1 and C3. They were used to find residential conditioned flat roof area (ROOF AREA) as in equation [1], which is displayed in Table 4-1, and in more detail, with saturations, in Table C-3.

$$
\text { ROOF AREA }=\frac{N \times A R E A}{F L R} \times S A T
$$

\section{Commercial}

Commercial building stock data were collected from the Commercial Building Energy Consumption Survey (CBECS, 1994). CBECS divided the U.S. into 9 census divisions. Unfortunately, the commercial data was not disaggregated further into MSAs within each region. We assumed that building stock in each census division were distributed proportionally to population. For example, a city like Atlanta with $6.9 \%$ of the South Atlantic census division's population, was assumed to contain $6.9 \%$ of the South Atlantic division's commercial building stock. The population of each CBECS census division is listed in Table C-2.

CBECS divided commercial buildings into 21 principal building activities. For this study, the principle building activities were reduced to seven (office, retail store, primary and secondary schools, hospital, nursing home, and grocery store) with the remainder neglected. We divided the office and retail store CBECS data for each census division into two categories based on the year of the buildings' construction, built either before 1980 (old) or during 1980 or later (new). We assumed the characteristics for each of these building types to be uniform throughout each census division. Therefore, the building characteristics in Atlanta, such as the total floor area (AREA), number of floors (FLR), and HVAC system saturations (SAT), were assumed to be the same as the building characteristics in the South Atlantic census division. These characteristics were used to find commercial conditioned flat roof area (ROOF AREA) as in equation [2], which is displayed in Table 4-1, and in more detail, with saturations, in Table C-3.

\footnotetext{
${ }^{6}$ All data contained in the AHS were adjusted to cover housing built in the years up to and including 1990.
} 


$$
\text { ROOF AREA }=\frac{A R E A}{F L R} \times S A T
$$

The Mountain and Pacific census divisions cover very large and varied terrain. To better represent Phoenix and Los Angeles we split these two divisions based on the number of heating degree days $\left(65^{\circ} \mathrm{F}\right)$. The Mountain region was split into "north" for heating degree days greater than 5500, and "south" for the remainder. Phoenix fell into the "south" Mountain region. The Pacific region was split into "north" for heating degree days greater than 4000 , and "south" for the remainder, which included Los Angeles.

\section{Summary}

The old residence accounted for $51 \%$ of the total conditioned flat roof area of $12.9 \mathrm{Bft}^{2}$, and the total residential representation was $76 \%$, offices added $8 \%$, and retail stores $9 \%$. These six building types accounted for $93 \%$ of the total conditioned flat roof area of the 11 MSAs. 
Table 4-1. Conditioned flat roof area of residential and commercial building stock.

\begin{tabular}{|l||c|c||r|}
\hline \multirow{2}{*}{\multicolumn{1}{|c||}{ metropolitan area }} & \multicolumn{3}{c|}{ conditioned flat roof area $\left(\mathrm{Mft}^{2}\right)$} \\
\cline { 2 - 4 } & residential & commercial & total \\
\hline \hline Atlanta & 818 & 92 & 910 \\
Chicago & 765 & 368 & 1133 \\
Los Angeles & 1152 & 598 & 1750 \\
Dallas/Fort Worth & 1452 & 317 & 1769 \\
Houston & 1228 & 303 & 1530 \\
Miami/Fort Lauderdale & 855 & 103 & 958 \\
New Orleans & 422 & 115 & 537 \\
New York & 338 & 621 & 959 \\
Philadelphia & 542 & 203 & 745 \\
Phoenix & 952 & 142 & 1093 \\
DC/Baltimore & 1326 & 204 & 1531 \\
\hline \hline Total & 9850 & 3066 & 12915 \\
\hline
\end{tabular}

\begin{tabular}{|l||c|}
\hline \multicolumn{1}{|c||}{ building type } & conditioned flat roof area $\left(\mathrm{Mft}^{2}\right)$ \\
\hline \hline Residence Old & 6630 \\
Residence New & 3219 \\
Office Old & 637 \\
Office New & 334 \\
Retail Store Old & 859 \\
Retail Store New & 292 \\
School & 708 \\
Hospital & 68 \\
Nursing Home & 89 \\
Grocery Store & 79 \\
\hline \hline Total & 12915 \\
\hline
\end{tabular}




\section{Chapter 5}

\section{Metropolitan-Scale and National HVAC Energy and Monetary Savings}

\section{Savings in Eleven Metropolitan Statistical Areas}

Metropolitan-scale HVAC annual electricity and net energy savings, peak electricity demand savings, and annual natural gas deficit were estimated by taking the product of the building-scale energy and monetary savings (Table B-19), the conditioned flat roof area (Table C-3), and the ratio of the local change in albedo to the change our simulations are based on. The savings are displayed in Table D-1. Below are examples of metropolitan-scale electricity savings for residential and office buildings in the South (Los Angeles) and North (Chicago).

- Example 1: In Los Angeles, single-story, old vintage residences with air conditioning and gas furnace heating (conditioned flat roof area of $954 \mathrm{Mft}^{2}$ ) saved $238 \mathrm{kWh} / 1000 \mathrm{ft}^{2}$ of electricity for each residence. They had a local base albedo of $0.30(\Delta \mathrm{a}=0.25)$ instead of $0.25(\Delta \mathrm{a}=0.30)$. This resulted in a modified total electricity savings of $189 \mathrm{MWh}$ for these residences in Los Angeles.

- Example 2: In Los Angeles, single-story, old vintage office buildings with air conditioning and gas furnace heating (conditioned flat roof area of $144 \mathrm{Mft}^{2}$ ) saved $377 \mathrm{kWh} / 1000 \mathrm{ft}^{2}$ of electricity for each office. They had a local base albedo of $0.32(\Delta \mathrm{a}=0.38)$ instead of 0.25 $(\Delta \mathrm{a}=0.45)$. This resulted in a modified total electricity savings of $45 \mathrm{MWh}$ for these office buildings in Los Angeles.

- Example 3: In Chicago, single-story, old vintage residences with air conditioning and gas furnace heating (conditioned flat roof area of $545 \mathrm{Mft}^{2}$ ) saved $131 \mathrm{kWh} / 1000 \mathrm{ft}^{2}$ of electricity for each residence. They had a local base albedo of $0.20(\Delta \mathrm{a}=0.35)$ instead of 0.25 $(\Delta \mathrm{a}=0.30)$. This resulted in a modified total electricity savings of $83 \mathrm{MWh}$ for these residences in Chicago.

- Example 4: In Chicago, single-story, old vintage office buildings with air conditioning and gas furnace heating (conditioned flat roof area of $84 \mathrm{Mft}^{2}$ ) saved $191 \mathrm{kWh} / 1000 \mathrm{ft}^{2}$ of electricity for each office. They had a local base albedo of $0.18(\Delta \mathrm{a}=0.52)$ instead of $0.25(\Delta \mathrm{a}$ $=0.45$ ). This resulted in a modified total electricity savings of $19 \mathrm{MWh}$ for these office buildings in Chicago.

The annual cooling electricity savings in gigawatt hour (GWh), annual natural gas deficit in gigaBtu (GBtu), annual net energy savings in million dollar (\$M), and peak electricity demand savings in megawatt (MW) for all $11 \mathrm{MSA}$ are shown in Table 5-1. The same quantities per $1000 \mathrm{ft}^{2}$ roof area of air-conditioned buildings for each MSA are shown in Table 5-2. To illustrate the climate effect, the results are plotted in Figures 5-1 to 5-4, superimposed on a map of the United States with contours of annual cooling hours for a typical residential building. The data per 
$1000 \mathrm{ft}^{2}$ of roof area reflect the effects of climate, whereas the MSA savings are strongly affected by the sizes of the populations.

The largest potential for annual net energy savings was found for Phoenix ( $\$ 37 \mathrm{M})$, followed by Los Angeles (\$35M), Houston $(\$ 27 \mathrm{M})$, Miami/Fort Lauderdale $(\$ 20 \mathrm{M})$, Dallas/Fort Worth $(\$ 20 \mathrm{M})$, New York $(\$ 16 \mathrm{M})$, Chicago $(\$ 10 \mathrm{M})$, New Orleans $(\$ 9 \mathrm{M})$, Atlanta $(\$ 9 \mathrm{M})$, Washington DC/Baltimore (\$8M), and Philadelphia (\$3M).

For an entire MSA, savings depend on a combination of factors: in warmer areas there are larger savings per $\mathrm{ft}^{2}$ and higher saturation of air-conditioned buildings, these are multiplied by the populations. For example, a lower saturation of air conditioning and a lower magnitude of cooling energy use per $\mathrm{ft}^{2}$ of air-conditioned buildings are the reasons that the energy savings in Los Angeles are less than in Phoenix, despite its being 7 times more populous. Another factor of about $30 \%$ is introduced by the variation of roof albedos from north to south among the MSAs. Roofs in the North seem to be darker, which increases the opportunity for savings there. Another factor that affects the results for monetary savings is the local cost of electricity. The high price of electricity in New York $(\$ 0.16 / \mathrm{kWh})$ compared to Atlanta or New Orleans $(\$ 0.08 / \mathrm{kWh})$ causes the dollar savings in New York to be almost twice as much as Atlanta.

The annual electricity savings, annual natural gas deficit, annual net energy savings, and peak electricity demand savings totaled for all 11 MSA were 2.6 tera-watt hours (TWh) (200 kilo-watt hours per $1000 \mathrm{ft}^{2}$ roof area of air-conditioned buildings), $6.9 \mathrm{TBtu}\left(5\right.$ therms per $\left.1000 \mathrm{ft}^{2}\right), \$ 194$ million ( $\$ 15$ per $\left.1000 \mathrm{ft}^{2}\right), 1.7 \mathrm{GW}\left(135 \mathrm{~W}\right.$ per $\left.1000 \mathrm{ft}^{2}\right)$, respectively.

Six building types accounted for over $90 \%$ of the annual electricity and net energy savings: old residences were responsible for almost $55 \%$, new residences $15 \%$, and four other building types (old/new offices and old/new retail stores) together almost $25 \%$.

\section{National Savings}

The results for the 11 MSAs were extrapolated to estimate the savings in the entire United States. This extrapolation was done in two different ways, first by accounting for the climatic variations of the savings and second by scaling to the national population. The details of the climatic extrapolation method are discussed in Appendix E.

The climatic zone extrapolation is considered first. The MSAs were located in three climatically distinct zones as defined in the Residential Energy Consumption Survey (RECS, 1995). The hottest zone (5) contained the following MSAs: Phoenix, New Orleans, Houston, Dallas/Fort Worth, and Miami/Fort Lauderdale; zone (4): Atlanta and Los Angeles; and zone 3: Chicago, New York City, Philadelphia, and DC/Baltimore. Naturally, most of the savings were found in the hottest zone (5). These are shown in Table 5-3. This resulted in annual electricity savings of $11.1 \mathrm{TWh},(56 \%$ in zone $5,22 \%$ in zone 3 , and $22 \%$ in zone 3$)$, annual net energy savings of 
$\$ 850 \mathrm{M},(63 \%$ in zone $5,21 \%$ in zone 3 , and $16 \%$ in zone 3$)$, an annual gas deficit of $28.2 \mathrm{TBtu}$, and peak electricity demand savings of $7.2 \mathrm{GW}$.

National estimates were also derived from scaling by population, where the 1990 population of the $11 \mathrm{MSA}$ was 70 million and the entire United States was 249 million. The savings estimates from the $11 \mathrm{MSA}$ were increased by the ratio of 249 to 70 (3.56) and are shown in Table 5-3. This resulted in a reduction of $9.3 \mathrm{TWh}$ in annual electricity use, $\$ 680 \mathrm{M}$ in annual net energy payments, and $6.2 \mathrm{GW}$ in peak electricity demand. The associated heating penalty was 24.5 TBtu. The reduction in peak electricity demand is the equivalent of 12 to 14 power plants each of $0.5 \mathrm{GW}$ capacity. 
Table 5-1. Estimates of metropolitan-scale annual direct cooling electricity savings, annual natural gas penalty, net dollar savings, and peak electricity demand savings, resulting from application of light-colored roofing on residential and commercial buildings in 11 Metropolitan Statistical Areas. Net dollar savings are calculated using the local cost of electricity and gas. For example, in Phoenix, the average price of electricity and gas for commercial and residential consumers are: $1 \mathrm{kWh}$ costs $\$ 0.104$; and $1 \mathrm{MBtu} \$ 6.40$.

\begin{tabular}{|c|c|c|c|c|c|c|c|c|c|c|c|c|c|c|c|c|c|c|}
\hline \multirow{3}{*}{ Metropolitan Area } & \multicolumn{6}{|c|}{ Residential Savings } & \multicolumn{6}{|c|}{ Commercial Savings } & \multicolumn{6}{|c|}{ Residential and Commercial Savings } \\
\hline & \multicolumn{2}{|c|}{ elec } & \multicolumn{2}{|c|}{ gas } & \multirow{2}{*}{\begin{tabular}{c|} 
net \\
(M\$)
\end{tabular}} & \multirow{2}{*}{$\begin{array}{l}\text { peak } \\
\text { (MW) }\end{array}$} & \multicolumn{2}{|c|}{ elec } & \multicolumn{2}{|c|}{ gas } & \multirow{2}{*}{$\begin{array}{l}\text { net } \\
\text { M\$ })\end{array}$} & \multirow{2}{*}{$\begin{array}{c}\text { peak } \\
\text { (MW) }\end{array}$} & \multirow{2}{*}{\multicolumn{2}{|c|}{${ }_{G W h}$ elec }} & \multicolumn{2}{|c|}{ gas } & \multirow{2}{*}{$\begin{array}{l}\text { net } \\
(\mathrm{M} \$)\end{array}$} & \multirow{2}{*}{$\begin{array}{l}\text { peak } \\
\text { (MW) }\end{array}$} \\
\hline & & $d(M \otimes)$ & 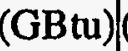 & $\mid(20<1\rangle$ & & & & $M \$)$ & (GBtu) ( & $(\mathrm{M} \$)$ & & & & & & $(\mathrm{M} \$)(\mathrm{C}$ & & \\
\hline tha & & 9.8 & -349 & -2.4 & 7.4 & 83 & 22 & 1.6 & -55 & -0.3 & 1.3 & 14 & 147 & 11.4 & -404 & $\mid-2.7$ & 8.7 & 9 \\
\hline Chic: & 100 & 11.2 & -988 & -5.4 & 5.8 & 89 & 84 & 7.0 & -535 & $|-2.7|$ & 4.3 & 56 & 183 & 18.2 & -1523 & $|-8.1|$ & 10.1 & 145 \\
\hline Los $\mathrm{A}$ & 210 & 20.6 & -471 & -2.9 & 17.7 & 218 & 209 & 18.6 & -154 & -0.9 & 17.7 & 102 & 419 & 39.2 & -625 & -3.8 & 35.4 & 320 \\
\hline Dallas / & 241 & 18.6 & -479 & -2.8 & 15.8 & 175 & 71 & 4.5 & -113 & -0.5 & 4.0 & 36 & 312 & 23.1 & -592 & -3.3 & 19.8 & 21 \\
\hline Hous & 243 & 22.6 & -284 & -1.7 & 20.9 & $127 \|$ & 79 & 6.0 & -62 & $-0.3 \mid$ & 5.7 & 30 & 322 & 28.6 & -347 & $|-2.0|$ & 26.6 & 15 \\
\hline Miami / Ft La & 221 & 17.9 & -4 & 0.0 & 17.9 & 115 & 35 & 2.4 & -3 & 0.0 & 2.4 & 11 & 256 & 20.3 & -7 & 0.0 & 20.3 & 125 \\
\hline New & 84 & 6.6 & -107 & -0.7 & 5.9 & 27 & 33 & 2.8 & -28 & -0.1 & 2.7 & 16 & 117 & 9.4 & -135 & $|-0.8|$ & 8.6 & 42 \\
\hline New & 35 & 5.6 & -331 & -2.7 & 2.9 & 56 & 131 & 16.5 & -540 & -3.3 & 13.2 & 95 & 166 & 22.1 & -871 & $|-6.0|$ & 16.1 & 151 \\
\hline Phila & 4 & 5.6 & -954 & -6.5 & -0.9 & 108 & 47 & 5.5 & -292 & -1.8 & 3.7 & 49 & 91 & 11.1 & -1246 & $|-8.3|$ & 2.8 & 157 \\
\hline Phoe & 299 & 32.0 & -74 & -0.5 & 31.5 & 106 & 58 & 5.3 & -31 & -0.2 & 5.1 & 18 & 357 & 37.3 & -105 & $|-0.7|$ & 36.6 & 123 \\
\hline $\mathrm{DC} / \mathrm{B}$ & 182 & 13.1 & -845 & -7.0 & 6.1 & 183 & 45 & 3.2 & -184 & -1.1 & 2.1 & 31 & 227 & 16.3 & -1029 & $|-8.1|$ & 8.2 & 214 \\
\hline tax & 84 & 3. & 286 & 32.6 & 131.0 & 1287 & 814 & 73.4 & 1997 & 11.2 & 62.2 & 458 & 2597 & 237.0 & 6884 & 43.8 & 33. & 174 \\
\hline
\end{tabular}


Table 5-2. Estimates of annual direct savings and penalties per $1000 \mathrm{ft}^{2}$ of roof area of air-conditioned buildings resulting from application of light-colored roofing on residential and commercial buildings in 11 Metropolitan Statistical Areas. Net dollar savings are calculated using the local cost of electricity and gas. For example, in Phoenix, the average price of electricity and gas for commercial and residential consumers are: $1 \mathrm{kWh}$ costs $\$ 0.104$; and 1 therm $=0.1 \mathrm{MBtu}$ costs $\$ 0.64$.

\begin{tabular}{|c|c|c|c|c|c|c|c|c|c|c|c|c|}
\hline \multirow[b]{2}{*}{ Metropolitan Area } & \multicolumn{4}{|c|}{ Residential Savings } & \multicolumn{4}{|c|}{ Commercial Savings } & \multicolumn{4}{|c|}{ Residential and Commercial Savings } \\
\hline & $\begin{array}{c}\text { elec } \\
(\mathrm{kWh})\end{array}$ & $\begin{array}{c}\text { gas } \\
\text { (therms) }\end{array}$ & $\begin{array}{r}\text { net } \\
(\$)\end{array}$ & $\begin{array}{l}\text { peak } \\
(\mathrm{W})\end{array}$ & $\begin{array}{c}\text { elec } \\
(\mathrm{kWh})\end{array}$ & $\begin{array}{c}\text { gas } \\
\text { (therms) }\end{array}$ & $\begin{array}{l}\text { net } \\
\text { (\$) }\end{array}$ & $\begin{array}{l}\text { peak } \\
(W)\end{array}$ & $\begin{array}{c}\text { elec } \\
(\mathrm{kWh})\end{array}$ & $\begin{array}{c}\text { gas } \\
\text { (therms) }\end{array}$ & $\begin{array}{r}\text { net } \\
(\$)\end{array}$ & $\begin{array}{l}\text { peak } \\
\text { (W) }\end{array}$ \\
\hline Atlanta & 153 & -4 & 10 & 102 & 239 & -6 & 11 & 152 & 162 & -4 & 10 & 107 \\
\hline Chicago & 131 & -13 & 8 & 116 & 228 & -15 & 11 & 152 & 162 & -13 & 9 & 128 \\
\hline Los Angeles & 182 & -4 & 16 & 189 & 350 & -3 & 30 & 171 & 239 & -4 & 20 & 183 \\
\hline Dallas / Ft Worth & 166 & -3 & 11 & 121 & 224 & -4 & 13 & 114 & 176 & -3 & 11 & 119 \\
\hline Houston & 198 & -2 & 17 & 103 & 261 & -2 & 20 & 99 & 211 & -2 & 18 & 102 \\
\hline Miami / Ft Lauderdale & 259 & 0 & 21 & 135 & 340 & 0 & 19 & 107 & 267 & $\mathbf{0}$ & 21 & 131 \\
\hline New Orleans & 199 & -3 & 14 & 64 & 287 & -2 & 26 & 139 & 218 & -3 & 17 & 78 \\
\hline New York & 104 & -10 & 9 & 166 & 211 & -9 & 21 & 153 & 173 & -9 & 17 & 158 \\
\hline Philadelphia & 81 & -18 & -2 & 199 & 232 & -14 & 20 & 241 & 122 & -17 & 4 & 211 \\
\hline Phoenix & 314 & -1 & 34 & 111 & 409 & -2 & 35 & 127 & 327 & -1 & 34 & 113 \\
\hline DC/ Baltimore & 137 & -6 & 5 & 138 & 221 & -9 & 10 & 152 & 148 & -7 & 5 & 140 \\
\hline
\end{tabular}




\section{Figure 5-1: Annual Net Dollar Savings for 11 Metropolitan Areas}

Net \$ Savings = \$ Cooling Energy Savings - \$ Heating Energy Penalties

The contour map shows simulated annual cooling hours for a typical house (Source: Kelly \& Parken 1978).

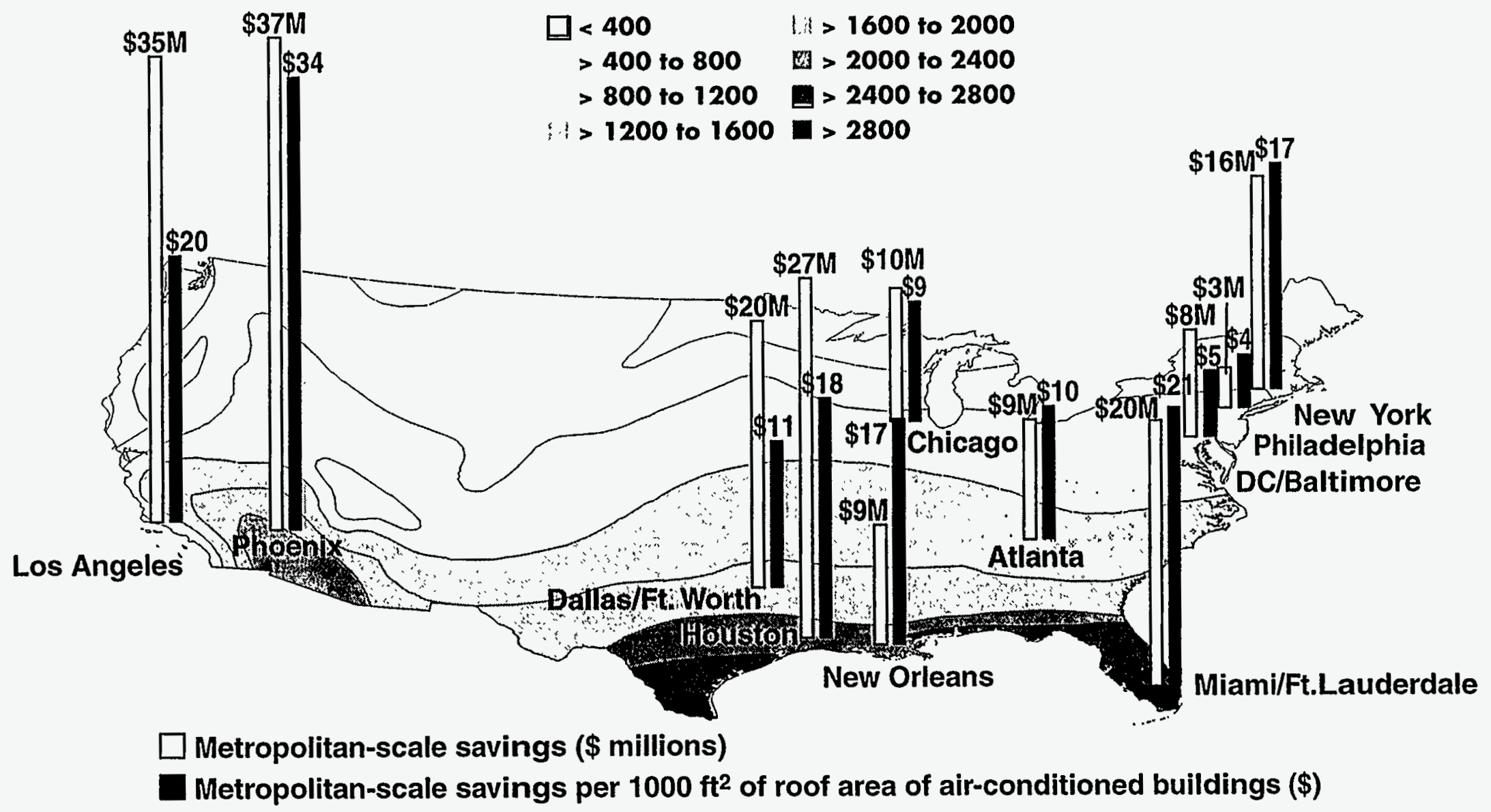




\section{Figure 5-2: Annual Cooling-Electricity Savings for 11 Metropolitan Areas}

The contour map shows simulated annual cooling hours for a typical house (Source: Kelly \& Parken 1978).

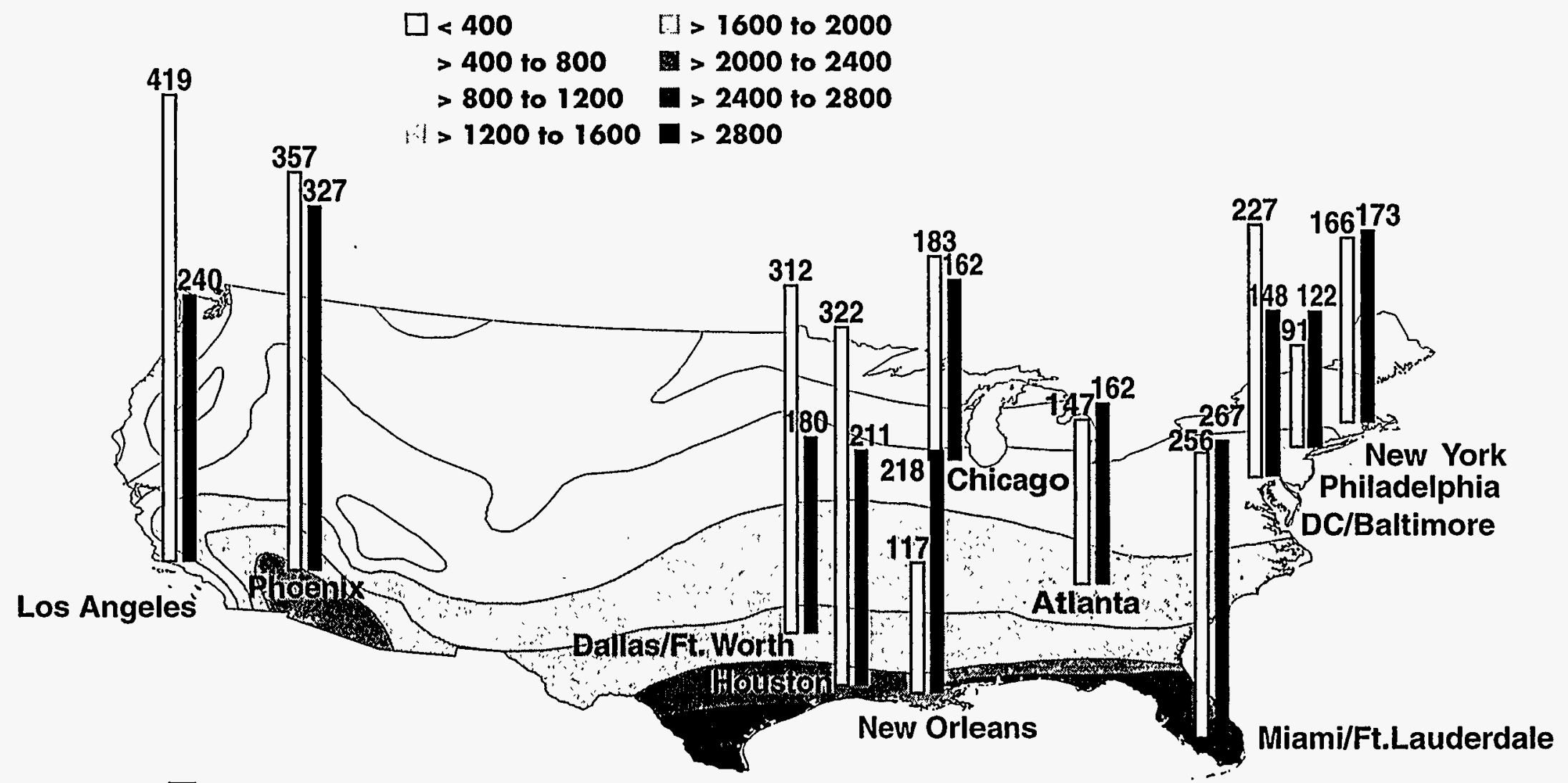

$\square$ Metropolitan-scale savings (GWh)

Metropolitan-scale savings per $1000 \mathrm{ft}^{2}$ of roof area of air-conditioned buildings (kWh) 


\section{Figure 5-3: Annual Heating Energy Penalties for 11 Metropolitan Areas}

The contour map shows simulated annual cooling hours for a typical house (Source: Kelly \& Parken 1978).

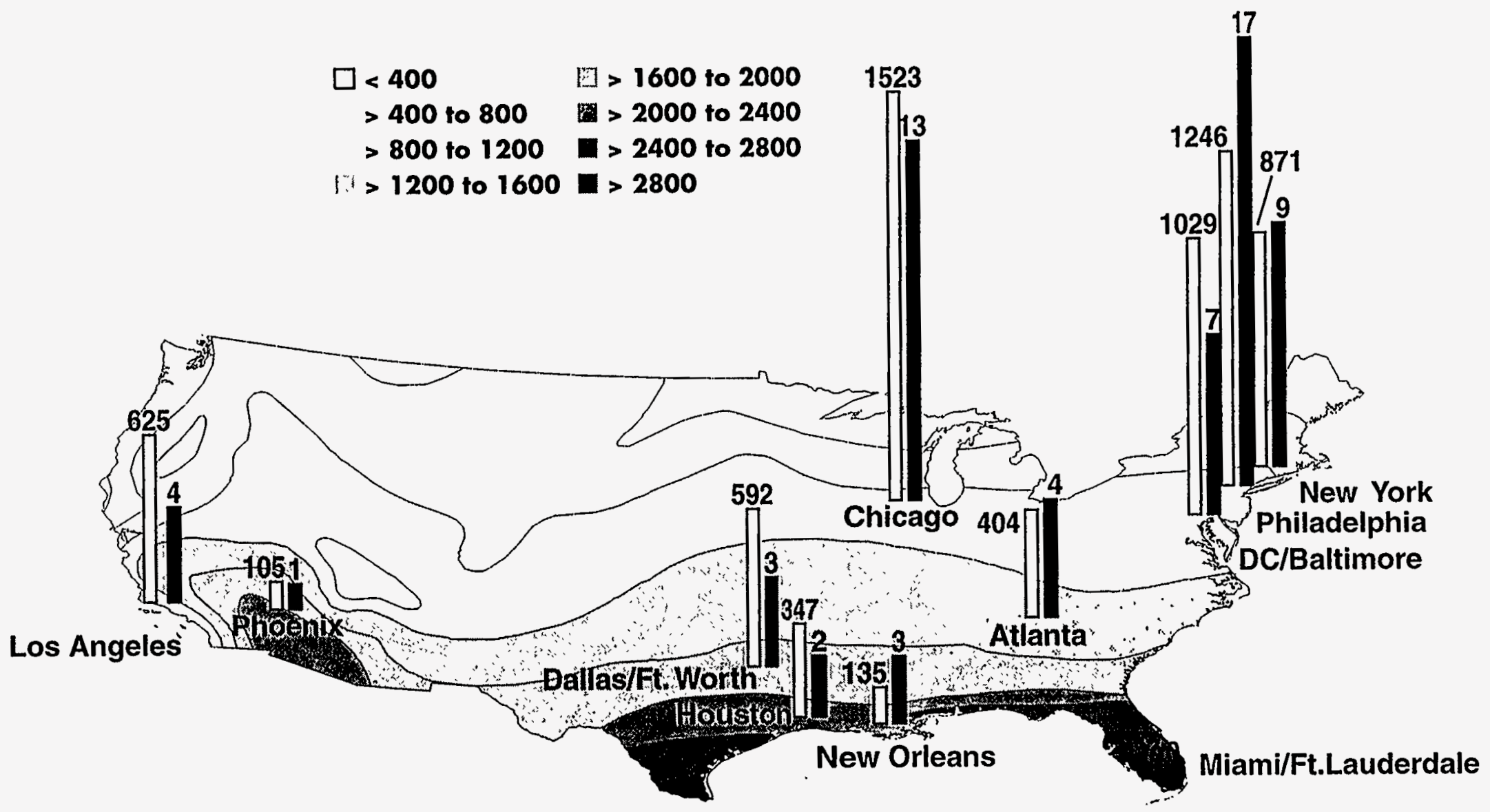

$\square$ Metropolitan-scale penalties (GBtu)

Metropolitan-scale penalty per $1000 \mathrm{ft}^{2}$ of roof area of air-conditioned buildings (Therms) 


\section{Figure 5-4: Peak-Cooling Electricity Demand Savings for 11 Metropolitan Areas}

The contour map shows simulated annual cooling hours for a typical house (Source: Kelly \& Parken 1978).

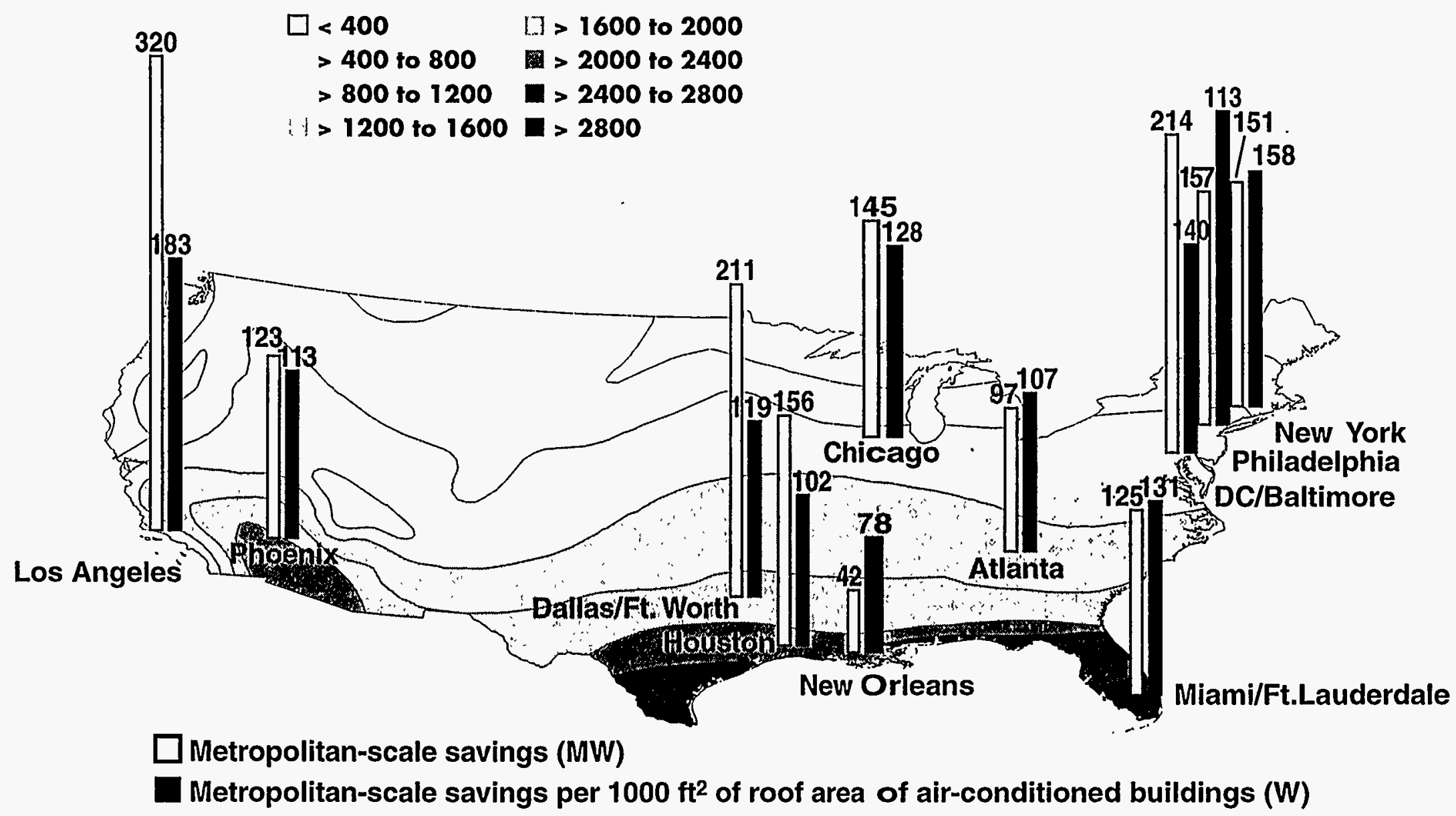


Table 5-3. Potential national energy savings resulting from the application of light-colored roofs to residential and commercial buildings.

\begin{tabular}{|l||c||c|}
\hline \multicolumn{1}{|c||}{\multirow{2}{*}{ savings type }} & \multicolumn{2}{c|}{ extrapolation by } \\
\cline { 2 - 3 } & climate zone & population \\
\hline \hline Electricity [TWh] & & \\
Residential & 7.7 & 6.3 \\
Commercial & 3.5 & 2.9 \\
Total & $\mathbf{1 1 . 1}$ & $\mathbf{9 . 3}$ \\
\hline Natural Gas [TBtu] & & \\
Residential & -20.3 & -17.4 \\
Commercial & -7.9 & -7.1 \\
Total & $\mathbf{- 2 8 . 2}$ & $\mathbf{- 2 4 . 5}$ \\
\hline Net Energy [\$M] & & \\
Residential & 600 & 460 \\
Commercial & 250 & 210 \\
Total & $\mathbf{8 5 0}$ & $\mathbf{6 8 0}$ \\
\hline Peak Demand [GW] & & \\
Residential & 5.4 & 4.6 \\
Commercial & 1.9 & 1.6 \\
Total & $\mathbf{7 . 2}$ & $\mathbf{6 . 2}$ \\
\hline
\end{tabular}




\section{Chapter 6}

\section{Conclusion}

This study provides quantitative estimates of the amount of energy and money that lighter-colored roofs can save in the United States. As expected, the largest savings in individual buildings are in the hottest and sunniest cities. In Phoenix, for example, our DOE-2 simulations of an old residence predicted that a whiter roof results in savings of $\$ 51$ per year per $1000 \mathrm{ft}^{2}$ roof area of air-conditioned buildings. In Miami the comparable saving was $\$ 30$. The savings decrease as the climate gets cooler, but for most building types, net savings are positive in colder climates as far north as Chicago. Our study includes MSAs in the three warmest climate zones.

For an entire MSA, savings depend on a combination of factors: in warmer areas there are larger savings per $\mathrm{ft}^{2}$ and higher saturation of air-conditioned buildings, these are multiplied by the populations. For example, a lower saturation of air conditioning and a lower magnitude of cooling energy use per $\mathrm{ft}^{2}$ of air-conditioned buildings are the reasons that the energy savings in Los Angeles are less than in Phoenix, despite its being 7 times more populous. Another factor of about $30 \%$ is introduced by the variation of roof albedos from north to south among the MSAs. Roofs in the North seem to be darker, which increases the opportunity for savings there. Now that we have evidence that savings can be had in the North, whiter roofs can be encouraged there, as well as in the South. Another factor that affects the results for monetary savings is the local cost of electricity. The high price of electricity in New York $(\$ 0.16 / \mathrm{kWh})$ compared to Atlanta or New Orleans $(\$ 0.08 / \mathrm{kWh})$ causes the dollar savings in New York to be almost twice as much as Atlanta.

We have also extrapolated the MSA results to the entire U.S. Scaling according to climate zones shows that if the present roofs were changed to an optimum reflectivity, the savings would be about $750 \mathrm{M} \$$, and the reduction in peak demand is equivalent to avoiding more than 13 power plants of $0.5 \mathrm{GW}$ capacity. Of these savings, more than half are in the hottest part of the nation, but about $15 \%$ could come from the cooler, but populous, northern zone that includes New York and Chicago.

This report is the most comprehensive yet attempted to assess the benefits of cool roofs. There are several ways in which this research could be further advanced. The savings reported here are probably under-estimates because the DOE-2 simulations typically give results less than the savings measured experimentally. Our estimates can be improved as refinements are made in the DOE-2 program.

A simplifying assumption that was made in our analysis is to keep the size of the HVAC system constant, at the size appropriate to the dark roof. As we make the roof cooler, in some cases the cooling load will decrease so much that a smaller air conditioner may suffice to cool the building. 
In that case, there could be additional savings because a smaller, less expensive, a/c system might be installed. The smaller system may also handle the load more efficiently, giving continuing savings during use.

An issue that might be addressed in future research is the relative benefits of cooler roofs vs. roof insulation. Calculations, performed in support of standard 90.1 of the American Society for Heating, Refrigeration and Air-Conditioning Engineers (ASHRAE), indicates that use of whiter roofs can substantially reduce the need for roof insulation (Akbari and Konopacki, 1997). Furthermore, an optimum design of roof insulation to account for roof color, can both reduce initial investment in roof insulation and lower the annual energy use of the building.

The results of this research can be used to develop a national plan to implement light-colored roofs. A national plan should initially focus on hot climates (since cool roofs provide significant savings) and flat roof buildings (since materials for cool roofs are currently available in the market). Flat roof buildings are used mostly in commercial buildings as well as some homes. For sloped-roof homes, cool roof materials are mostly at the development stage. Efforts should focus on collaboration with the manufacturers of roofing material for sloped roofs (mostly shingles) to accelerate development and marketing of cool roofs. 


\section{Bibliography}

AHS. YEAR+4. ${ }^{7}$ American Housing Survey for the CITY Metropolitan Area in YEAR. U.S. Department of Commerce, Bureau of the Census, U.S. Department of Housing and Urban Development. Washington, DC.

Akbari, H., Bretz, S., Hanford, J., Kurn, D., Fishman, B., Taha, H., and Bos, W. 1993a. Monitoring Peak Power and Cooling Energy Savings of Shade Trees and White Surfaces in the Sacramento Municipal Utility District (SMUD) Service Area: Data Analysis, Simulations, and Results. Lawrence Berkeley National Laboratory Report LBL-34411. Berkeley, CA.

Akbari, H., Bretz, S., Hanford, J., Rosenfeld, A., Sailor. D., Taha, H., and Bos, W. 1992. Monitoring Peak Power and Cooling Energy Savings of Shade Trees and White Surfaces in the Sacramento Municipal Utility District (SMUD) Service Area: Project Design and Preliminary Results. Lawrence Berkeley National Laboratory Report LBL-33342. Berkeley, CA.

Akbari, H., Eto, J., Konopacki, S., Afzal, A., Rainer, L., and Heinemeier, K. 1993b. Integrated Estimation of Commercial Sector End-Use Load Shapes and Energy Use Intensities in the PG\&E Service Area. Lawrence Berkeley National Laboratory Report LBL-34263. Berkeley, CA.

Akbari, H., Eto, J., Turiel, I., Heinemeier, K., Lebot, B., Nordman, B., and Rainer, L. 1989. Integrated Estimation of Commercial Sector End-Use Load Shapes and Energy Use Intensities. Lawrence Berkeley National Laboratory Report LBL-27512. Berkeley, CA.

Akbari, H., and Konopacki, S. 1997. Calculations in Support of SSP90.1 for Reflective Roofs. Lawrence Berkeley National Laboratory Report LBL-40260. Berkeley, CA.

Akbari, H., Rainer, L., and Eto, J. 1991. Integrated Estimation of Commercial Sector End-Use Load Shapes and Energy Use Intensities, Phase II. Lawrence Berkeley National Laboratory Report LBL-30401. Berkeley, CA.

American Society of Heating, Refrigerating and Air Conditioning Engineers (ASHRAE). 1989. Fundamentals, Chapter 22, Table 5. Atlanta, GA.

Berdahl, P., and Bretz, S. 1995. Preliminary Survey of the Solar Reflectance of Cool Roofing Materials. Lawrence Berkeley National Laboratory Report LBL-36020. Berkeley, CA.

Boutwell, C., Salinas, Y., Graham, P., Lombardo, J., and Rothenberger, L. 1986. Building for the Future, Phase I, Vol. 1. Department of Construction and Architectural Engineering Technology. University of Southern Mississippi.

\footnotetext{
${ }^{7}$ Each location was surveyed every four years on varying 4 year rotations. For example, Chicago was surveyed in 1983, 1987 and 1991, while Phoenix was surveyed in 1981, 1985 and 1989. The most recent survey in publication was used for each of the cities studied in this report, which were: Atlanta, 1991; Chicago, 1991; Fort Worth, 1989; Houston, 1991; Los Angeles, 1985 (the most recent survey, 1989, was not available); Miami, 1990; New Orleans, 1990; New York, 1991; Philadelphia, 1989; Phoenix, 1989; Washington DC, 1993. The bibliographic entry is in a general format and the above cities and dates should be inserted.
} 
Bretz, S., and Akbari, H. 1994. Durability of High-Albedo Roof Coatings and Implications for Cooling Energy Savings. Lawrence Berkeley National Laboratory Report LBL-34974. Berkeley, CA.

Bretz, S., Akbari, H., and Rosenfeld, A. 1997. Practical Issues for Using Solar-Reflective Materials to Mitigate Urban Heat Islands. Lawrence Berkeley National Laboratory Report LBL-38170. Berkeley, CA.

Building Energy Simulation Group (BESG). 1990. Overview of the DOE-2 Building Energy Analysis Program, Version 2.ID. Lawrence Berkeley National Laboratory Report LBL-19735, Rev.1. Berkeley, CA.

California Energy Commission (CEC). 1994. Technology Energy Savings Volume II: Building Prototypes. Consultant Report P300-94-007. Sacramento, CA.

Commercial Buildings Energy Consumption Survey (CBECS). 1994. Commercial Buildings Characteristics, 1992. Energy Information Administration. Washington, DC.

Energy Information Administration (EIA). 1993a. Electric Sales and Revenue 1993. DOE/EIA-0540(93). Washington, DC.

Energy Information Administration (EIA). 1993b. Office of Oil and Gas, Reserves and Natural Gas Division. Roy Kass, 202-586-4790. Washington, DC.

Energy Information Administration (EIA). 1993c. Annual Energy Outlook 1993 - U.S. Energy End Use. DOE/EIA-0383(93). Washington, DC.

Gartland, L., Konopacki, S., and Akbari, H. 1996. Modeling the Effects of Reflective Roofing. Lawrence Berkeley National Laboratory Report LBL-38580. Berkeley, CA. "Proceedings of the 1996 ACEEE Summer Study on Energy Efficiency in Buildings." Asilomar, CA.

Huang, J., Ritschard, R., Bull, J., Byrne, S., Turiel, I., Wilson, D., Hsui, C., and Foley, D. 1987. Methodology and Assumptions for Evaluating Heating and Cooling Energy Requirements in New Single-Family Residential Buildings. Lawrence Berkeley National Laboratory Report LBL-19128. Berkeley, CA.

Kelly, G.E. and Parken, W. H. 1978. Method of testing, rating and estimating the seasonal performance of central air-conditioners and heat pumps operating in the cooling mode. NBSIR 77-1271, National Bureau of Standards. Washington, DC.

Parker, D., Barkaszi, S., Chandra, S., and Beal, D. 1995. Measured Cooling Energy Savings from Reflective Roofing Systems in Florida: Field and Laboratory Research Results. Florida Solar Energy Center (FSEC) Report FSEC-PF-293-95. Cocoa, FL.

Residential Energy Consumption Survey (RECS). 1995. Housing Characteristics, 1993. Energy Information Administration. Washington, DC.

Rosenfeld, A., Akbari, H., Bretz, S., Fishman, B., Kurn, D., Sailor, D., and Taha, H. 1995. Mitigation of Urban Heat Islands: Materials, Utility Programs, Updates. "Energy and Buildings 22." Berkeley, CA. 
Taha, H., Konopacki, S., and Akbari, H. 1996. Emission and Atmospheric Impacts of Reduced Urban Surface and Air Temperatures in the South Coast Air Basin. Lawrence Berkeley National Laboratory Report LBL-39298. Berkeley, CA.

Taha, H., Sailor, D., and Akbari, H. 1992. High-Albedo Materials for Reducing Building Cooling Energy Use. Lawrence Berkeley National Laboratory Report LBL-31721. Berkeley, CA.

U.S. Bureau of the Census. 1990. Database C90STF3C1, http://venus.census.gov/cdrom/lookup/.

U.S. Geological Survey (USGS). 1993. Standards for Digital Orthophotos. 


\section{Appendix A}

\section{Roof Albedo}

\section{Albedo Retrieval Procedure}

Albedo is defined as the fraction of the incident solar energy that is reflected. To determine it one has the choice of localized measurements, which are of high accuracy and resolution, but are impractical in covering the large areas we need. Or, one can take wide angle measurements from a distance, which provides suitable spatial coverage but the accuracy and resolution of the data strongly depend on many factors, such as the sensor's height (airplane or satellite), the sensor's characteristics (IFOV - Instantaneous Field Of View, bandwidth, the spectral range) and the weather conditions. Once the data is corrected for atmospheric effects, some method of calibrating the observed radiant intensity with known albedos is then needed. The albedo value at a particular point can be calculated as a weighted average of the band(s) (channel) reflectances from that surface.

The altitude of the orbits of satellites (about $100 \mathrm{mi}$ ) limits the ground resolution of commercial satellite photographs from approximately $1 \mathrm{~km}$ (AVHRR) to $30 \mathrm{~m}$ (Landsat-TM), down to $10 \mathrm{~m}$ (SPOT). Unfortunately, these values are too coarse for the analysis of individual buildings. On the other hand, photographs from aircraft (usually taken at an altitude of about $4 \mathrm{mi}$ ) provides spatial coverage with resolution down to $1 \mathrm{~m}$. However, this source of data usually lacks spectral information. Aircraft pictures are usually taken on panchromatic black and white, or infrared film. Multi-spectral sensors originally designed for satellite use can be mounted on an airplane, thus providing the additional spectral information, but at a higher cost.

High quality aerial photographs are sometimes available from the planning, zoning, or engineering departments of city or county governments. We tried to obtain copies for analysis in our laboratory (we can scan photographs into a computer, and then use programs that can give the grayscale values of the selected roofs and their surface areas). However, the quality of such copies of photos varies widely and most are not of sufficiently accurate contrast to be useful.

Fortunately, the National Digital Orthophoto Program (NDOP) is in the process of producing digitized aerial photographs of the entire United States, which is to be completed by the year 2001. Digitization means that degrees of lightness on panchromatic black and white photographs are represented as digital data. The digitized photographs are of sufficient resolution that individual buildings can be identified. The digital value of a roof's "grayness" can be read out. This data has the advantage of having been digitized from high quality original photographs taken for the National Aerial Photography Program, but we are not certain about how much processing has been done on the data. We then calibrate the digital readings into albedo by correlating surfaces of known albedo (asphalt, concrete, grass, etc.) with their digitized "graynesses". Using this correlation, we then convert the digitized data of roofs to their corresponding albedos. 


\section{Data and Processing}

The digitizations of aerial photographs of three of the cities of interest for this project; Atlanta, Philadelphia, and Washington DC, have already been completed by NDOP. These photographs are available from the U.S. Geological Survey $\left(\mathrm{USGS}^{8}\right)^{8}$. The resolution is about one pixel per 1 $\mathrm{m}$ and is sufficient for our purposes. In addition, the data have been subjected to orthographic projection ${ }^{9}$, a vertical projection like a map. This results in "Digitized Orthophotos". The area of coverage of 7.5 minutes of latitude and longitude is called a "quadrangle", so that the data is referred to as a Digital Ortho Quadrangle (DOQ). It may be divided in four into "quarter quadrangles" (DOQQ), of extent 3.75 minutes of latitude and longitude.

The original photographs are taken at the center of a particular quarter-quadrangle at a flying height of 20,000 feet above mean terrain (photography scale $=1: 40,000$ ). After the photo has been digitalized it is rectified to an orthographic projection. The rectified image is then archived on a digital medium with a header containing descriptive information inserted as the first four records of the file. A typical DOQQ file contains approximately 7500 rows by 6500 columns with 8 bits per pixel (USGS, 1993), thus the file size is about 50 megabytes. Image brightness is represented by the 8 bits to give 256 levels per pixel. A value of 0 represents black and a value of 255 white.

In our study of Atlanta we used 16 DOQQs, which when put together formed 4 DOQs covering the urbanized area and some of its surroundings. The exact extent encompassed the area from -84.25 degrees to -84.5 degrees of geographic longitude and from 33.625 degrees to 33.875 degrees of geographic latitude (approx. $780 \mathrm{~km}^{2}$ ).

In the process of image manipulation we stripped off the descriptive ASCII image headers and only the raw (binary) pixel data were displayed. The size of each DOQQ caused some problems. The files were too large to be handled by our programs. However, they could resample the data displaying one in ten pixels. Once the DOQQ was visualized at this lower resolution we could select a desired neighborhood and then extract the original data for this "sub-image". Thus, we achieved images of neighborhoods at the original high resolution. Photographs of residential and commercial buildings in Atlanta are shown in Figures A-1 and A-2, respectively.

The sub-image analysis provided us with details and recognizable features contained in a particular image. Therefore, we were able to identify roofs, paved surfaces, lawns, trees, etc. By pointand-click, the objects grayness value was rapidly read and directed into a file of similar

\footnotetext{
${ }^{8}$ U.S. Geological Survey (USGS), Earth Science Information Center, 507 National Center, Reston, VA 22092.

${ }^{9}$ An orthographic projection is produced from a digitized perspective aerial photograph by differential rectification so that image displacements (radial deformations) caused by camera tilt and relief of terrain are removed. This process requires, as input, ground control points and a Digital Elevation Model (DEM). Digitized Orthophotos are geo-referenced in Universal Transverse Mercator (UTM) projection, with coordinates in meters, cast on North American Datum of 1983 (NAD 83).
} 


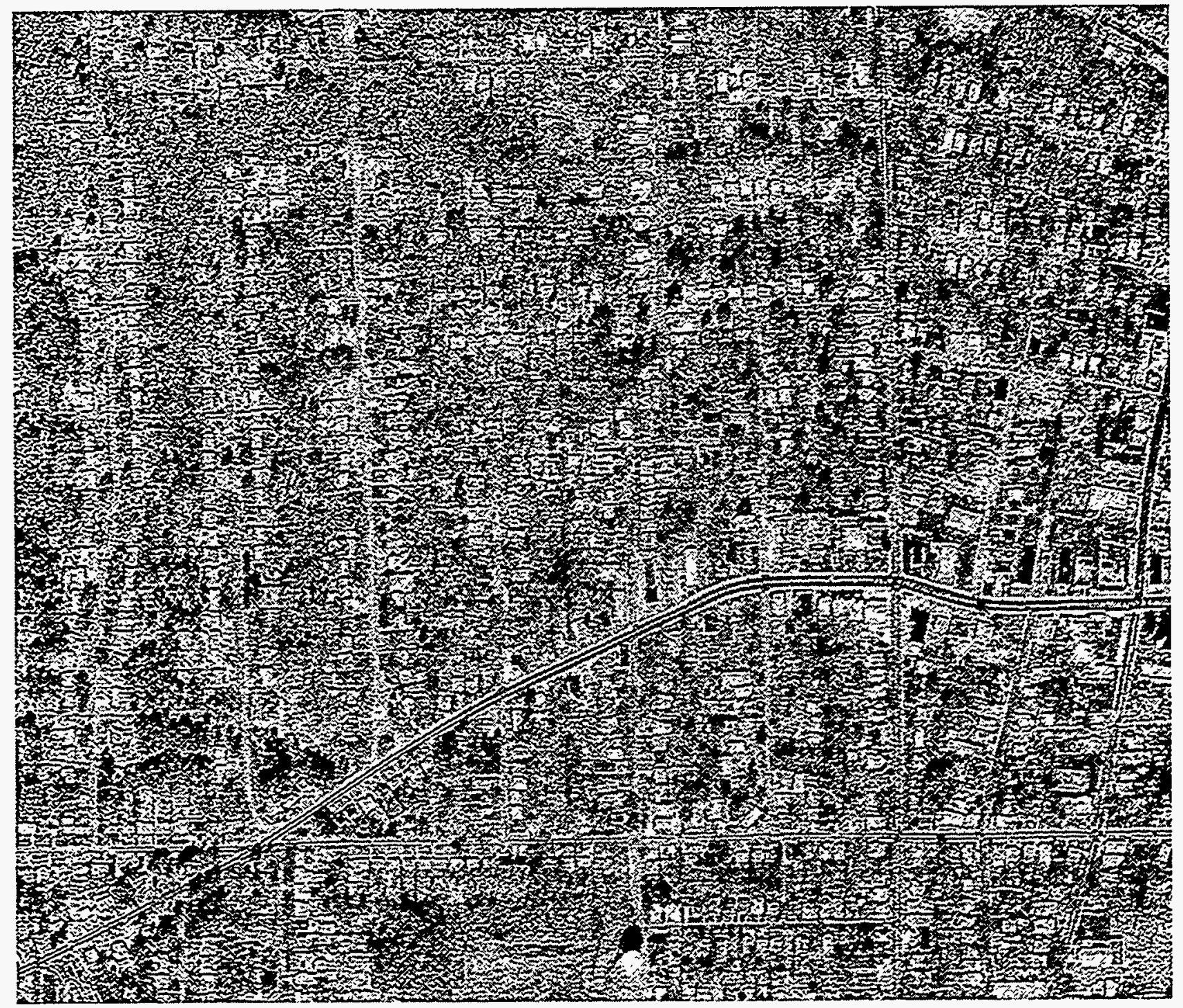

Figure A-1. Sub-image containing residential buildings in Atlanta with $1 \mathrm{~m}$ resolution. 


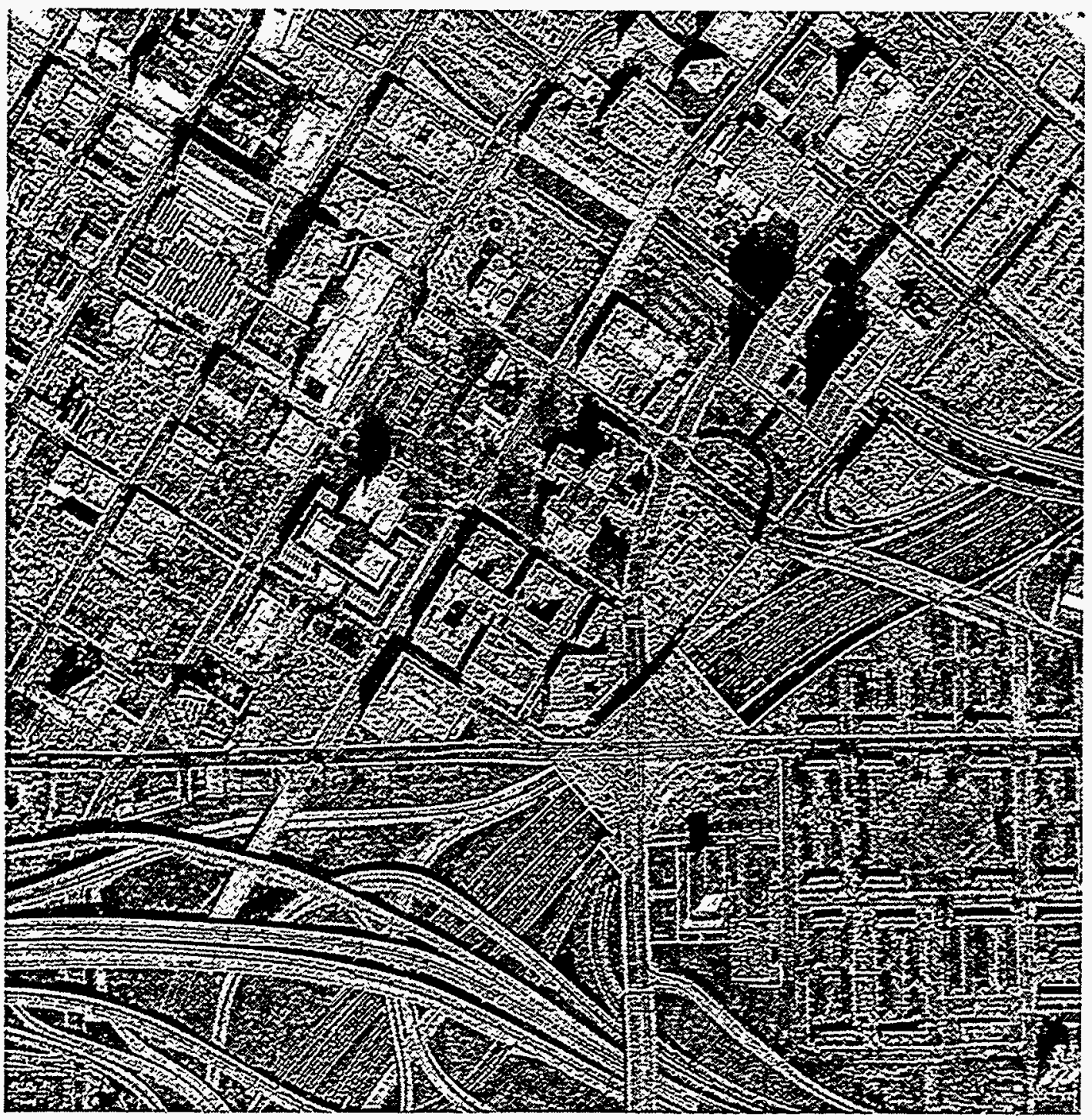

Figure A-2. Sub-image containing commercial buildings in Atlanta with $1 \mathrm{~m}$ resolution. 
objects. Sampling was performed randomly on sub-images. In going from one sub-image to the next, we checked that points that appeared in both images, where they overlapped had similar grayness values. This was to mitigate the problems that result from possible distortions of the grayness levels of the DOQQs before we received the data, which are described below.

\section{Calibration of Grayness vs. Albedo}

The grayness levels of interesting objects was converted to albedo. We did this by selecting surfaces whose albedos were known, and correlated the grayness values to these albedos. Surfaces used for the calibration of the grayness vs measured values of albedo were chosen to (a) span the range from low albedo to high, (b) be easily recognizable features on the image, and (c) be as homogeneous as possible. For example, in Atlanta, the graynesses of dark asphalt, weathered asphalt, grass, concrete surfaces and the roof of the Georgia Dome were utilized as calibration points. The roof of the Georgia Dome Stadium is very white and thus was a particularly handy reference point. These provided us with an average and range of grayness values for each surface. Next, we compared them with known (Taha, et al., 1992) albedos of the same kinds of surfaces as shown in Table A-1. The roof of the Georgia Dome, made of teflon coated fiberglass (Sheerfill ${ }^{\circledR}$ ), represented the high-end with albedo value of 0.72 (the value was provided by the manufacturer ${ }^{10}$ ). At the low-end dark asphalt albedo values were chosen. Since these surfaces reflect more diffusely than water, we preferred them to water as a reference point. In the choice of surfaces to measure, it was best to avoid those that were in the direction of the sun. Specular reflection can cause these areas to appear to have erroneously high albedos.

To find a mathematical relationship between grayness and albedo, we first tried a simple linear model, equation [3], where $G$ is grayness and $A$ is albedo.

$$
\mathrm{G}=\mathrm{mA}+\mathrm{b}
$$

The regression analysis had a high correlation $\left(\mathrm{R}^{2}=0.94\right)$, but it predicted an impossible result for the intercept value, $b=69.7$. In other words, a surface with grayness less than the intercept would have a negative albedo, see Figure A-3. Therefore, a square root fitting was tested, equation [4].

$$
\mathrm{G}=m A^{1 / 2}+b
$$

It showed a similarly high correlation $\left(R^{2}=0.94\right)$, but the intercept, $b=1.8$, is close enough to zero to prevent negative albedos, see Figure A-4. Our goal was to determine albedo values from grayness. Equations [5] and [6] express this relation.

\footnotetext{
${ }^{10}$ Chemfab Corporation, 701 Daniel Webster Highway, PO Box 1137, Merrimack, NH 03054.
} 


$$
\begin{gathered}
A=[(G-b) / m]^{2} \\
A=[(G-1.8) / 290.9]^{2}
\end{gathered}
$$

Table A-1. Albedo and Grayness Values for Surfaces in Atlanta.

\begin{tabular}{|l||r|r|}
\hline \multicolumn{1}{|c||}{ Surface } & \multicolumn{1}{c|}{ Albedo } & \multicolumn{1}{c|}{ Grayness } \\
\hline \hline Dark Asphalt & $0.05-0.08$ & $64-108$ \\
Weathered Asphalt & $0.13-0.15$ & $89-126$ \\
Grass & $0.18-0.22$ & $105-133$ \\
Concrete & $0.30-0.36$ & $157-185$ \\
Sheerfill ${ }^{\circledR}$ & 0.72 & 255 \\
\hline
\end{tabular}

Our next step was to collect samples of roofs' grayness values for residential and commercial buildings. Figures $\mathbf{A}-5$ and $\mathbf{A}-6$, respectively show histograms of the Atlanta distributions of the grayness values for residential and commercial buildings (divided into 20 levels each with bin width of 13). We randomly sampled 888 residential roofs and 129 commercial roofs in Atlanta. Converting the individual grayness values to albedos, using equation [6], then taking the average albedo, we find the average albedo of residences was 0.30 and for commercial buildings the average albedo was 0.32 . These values seem rather high considering that the albedo of new "white" roof asphalt shingles was measured (Berdahl and Bretz, 1995) to be about 0.25 .

A similar procedure was applied to the data available from the NDOP for Philadelphia and Washington DC. In Table A-2 we show the cities analyzed, the number of roofs measured and the estimated average albedos for residential and commercial buildings. We note that the average albedo increased north to south, denoting lighter colored roofs in the South.

Table A-2. Estimated average roof albedos of residences and commercial buildings and sample size for Atlanta, Philadelphia, and Washington, DC.

\begin{tabular}{|l||c|c||c|c|}
\hline \multicolumn{1}{|c||}{\multirow{2}{*}{ city }} & \multicolumn{2}{c||}{ residences } & \multicolumn{2}{c|}{ commercial } \\
\cline { 2 - 5 } & albedo & sample size & albedo & sample size \\
\hline \hline Atlanta & 0.30 & 888 & 0.32 & 129 \\
Washington DC & 0.25 & 859 & 0.25 & 243 \\
Philadelphia & 0.20 & 1292 & 0.18 & 172 \\
\hline
\end{tabular}




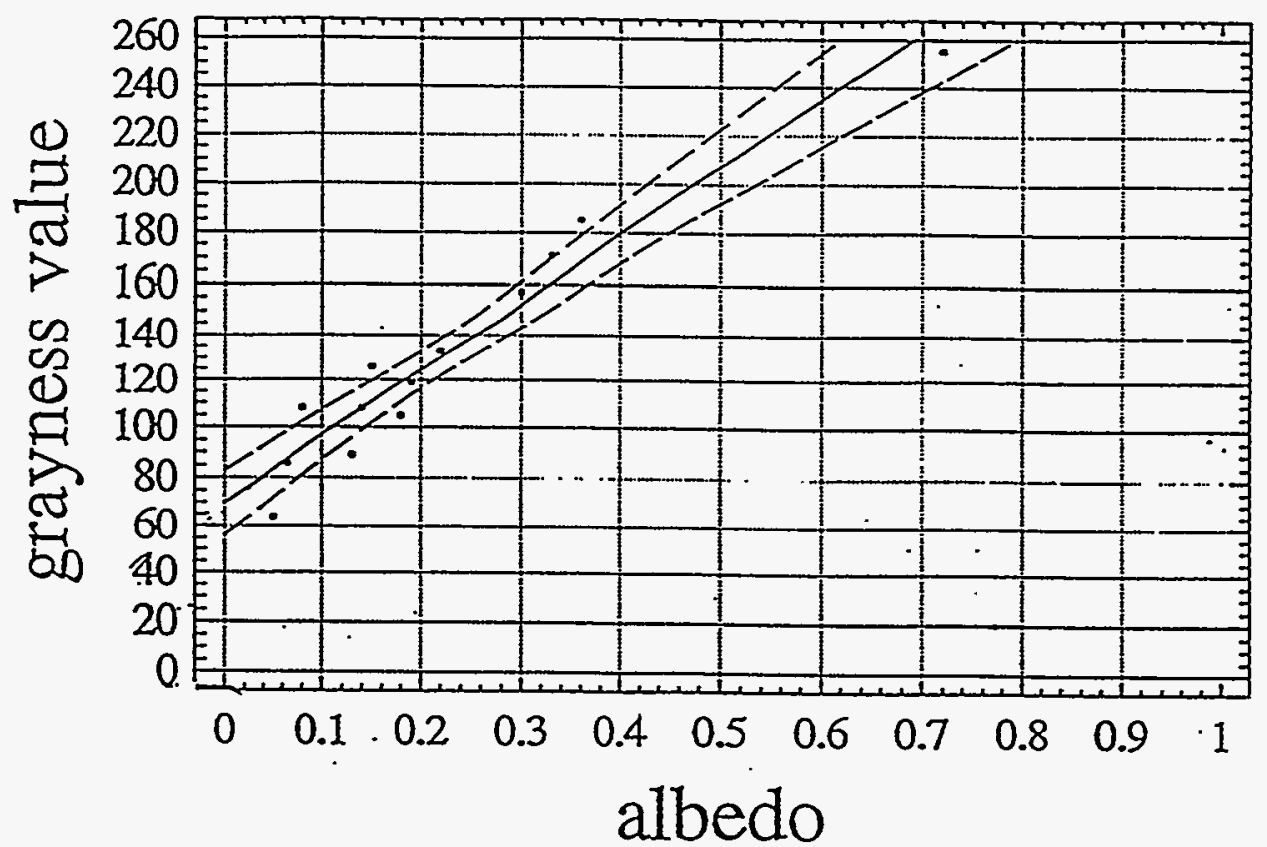

Figure A-3. Plot of fitted linear model.

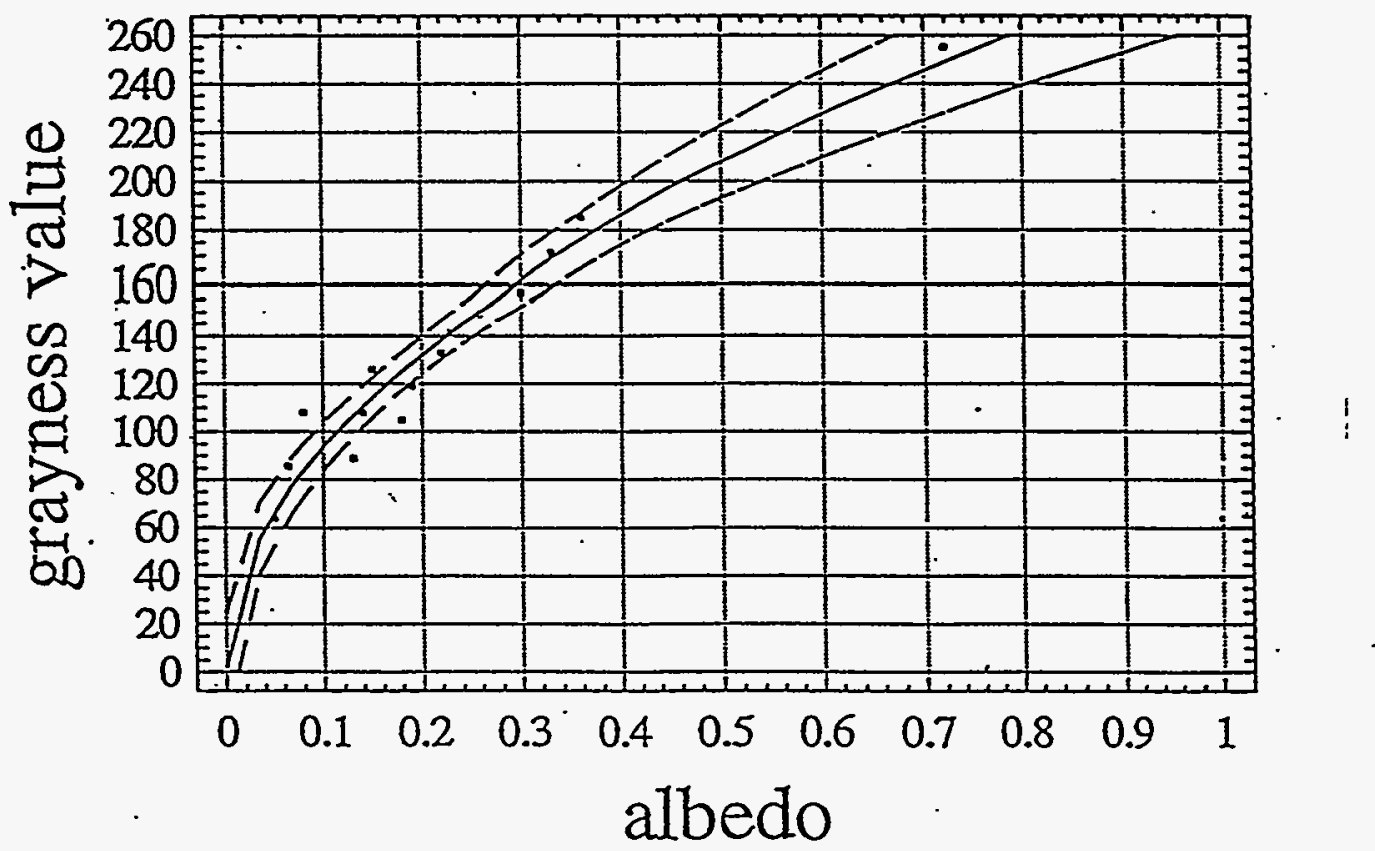

Figure A-4. Plot of fitted square root model. 


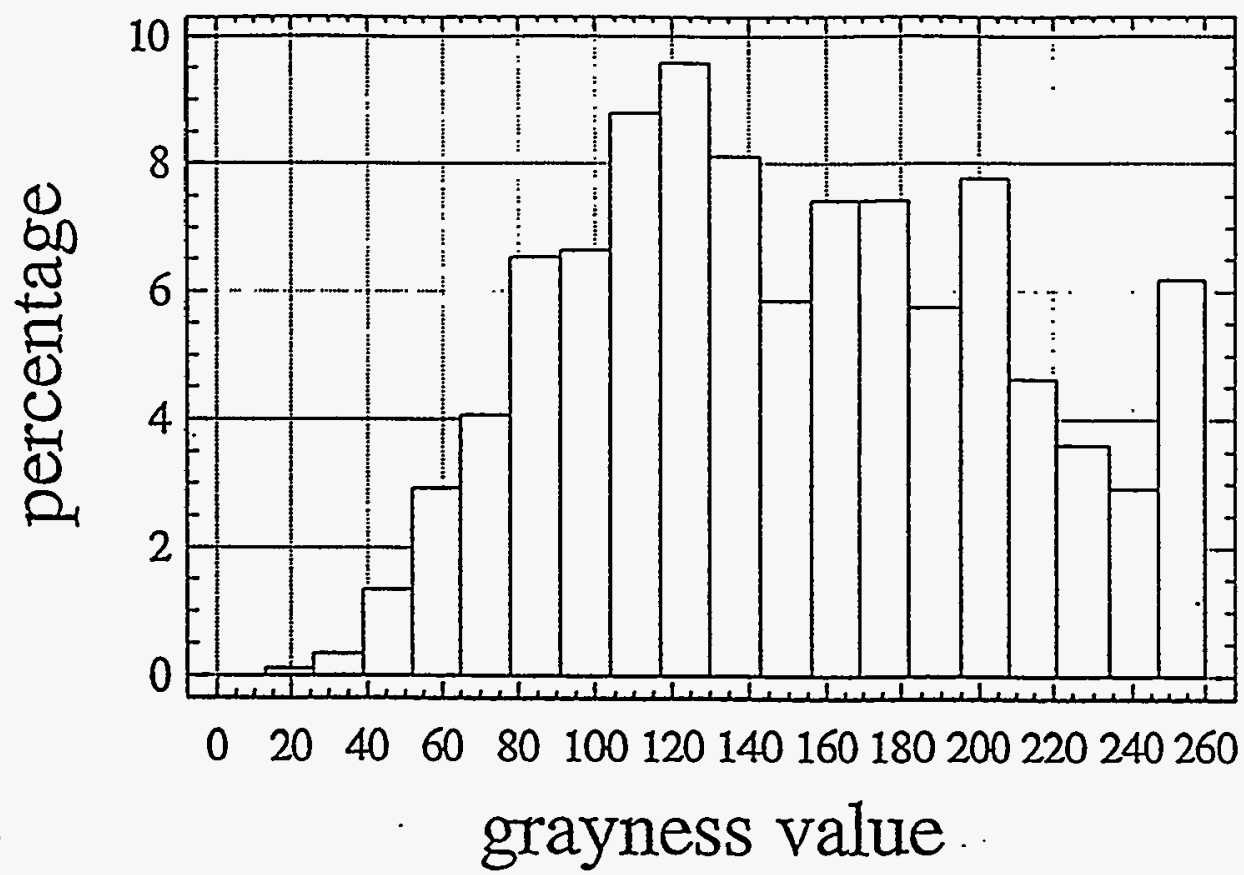

Figure A-5. Relative frequency histogram for distribution of grayness̄ of residential building's roofs (20 bins, bin width $=13$ ).

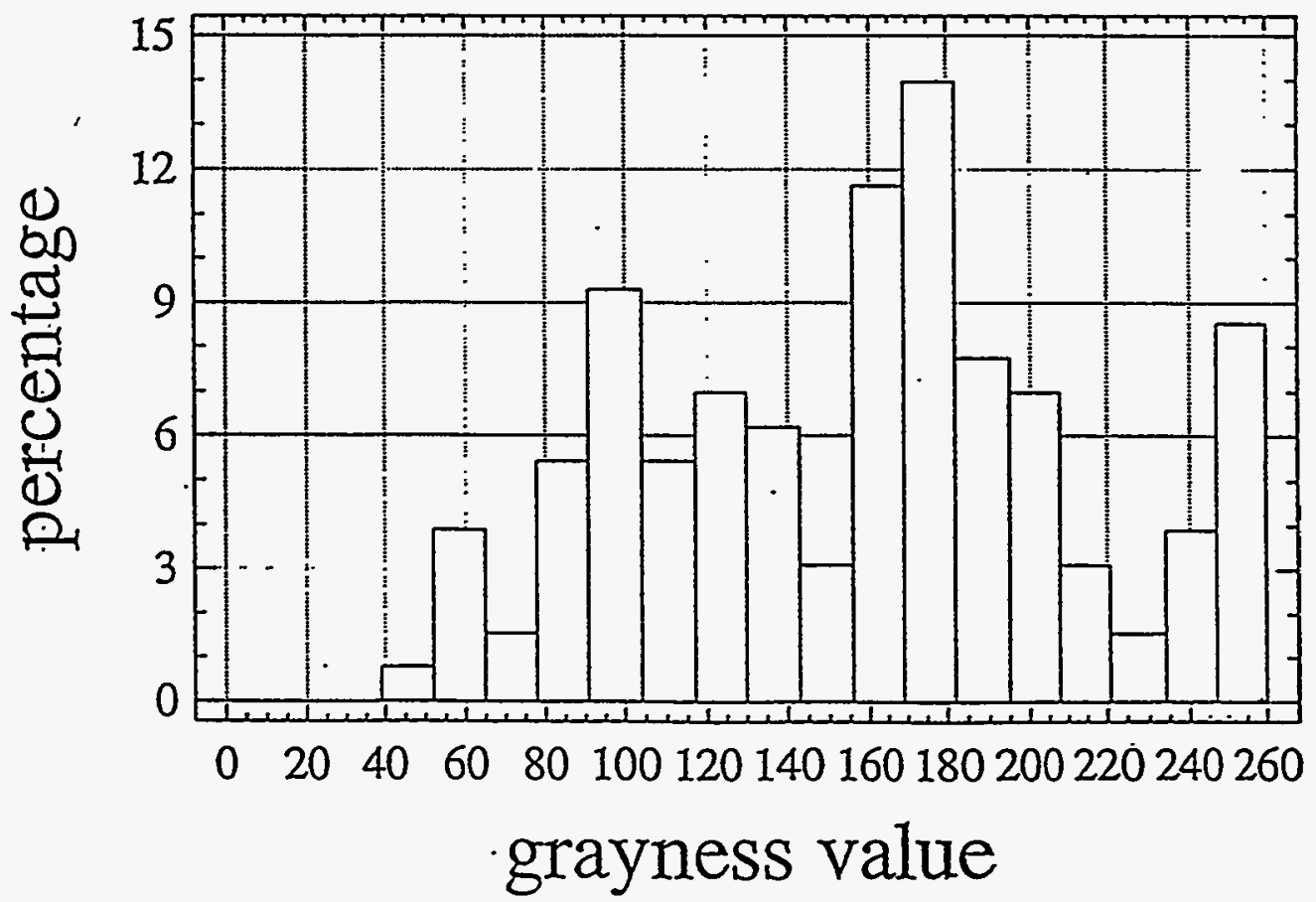

Figure A-6. Relative frequency histogram for distribution of grayness of commercial building's roofs (20 bins, bin width $=13$ ). 


\section{Discussion}

Our method, although very simple, proved the possibility of determining albedo values from digitized aerial photographs. It should be mentioned that this method is particularly valid for human-made surfaces. The explanation lies in the fact that human-made surfaces tend to have a more constant reflectivity over the visible and near IR spectral region. So, the visible reflectivity is a good approximation to the average albedo; whereas, vegetation reflects relatively more in the near infra-red part of the spectrum.

The question of consistency still remains. The same object in adjacent pictures will probably not have the same value of grayness, although similar, because of the effects of picture processing (USGS, 1993), such as "dodging" (or, shading of certain areas in picture) or "contrast stretching" (the practice of assigning the maximum (minimum) number to the brightest (darkest) pixel in a given set of data. With "stretching", the grayness is not absolute, but only relative to the particular set of pixels in that photograph. For example, if the Georgia Dome is the whitest point in its picture, it is assigned grayness is 255 and we know its albedo is 0.72 . In an adjacent picture, if the brightest surface has an albedo of 0.60 , its grayness will also be assigned 255 . This means that an object in the overlapping region of both pictures with albedo of 0.36 will be assigned two different grayness values: $0.36 / 0.72 * 255=128$ in the first picture and $0.36 / 0.60 * 255=153$ in the second. These effects could also be a possible reason for a better fit of the square root model compared to the linear.

In the future, when analyzing other cities one has to check image consistency and then derive from the consistent set of pictures a new, city specific, regression. We have also recently found a method for correction of stretching. 


\section{Appendix $B$}

\section{Building-Scale HVAC Energy and Monetary Data}

\section{Weather and Price of Energy Data}

The weather tapes used in DOE-2 building energy simulations and typical weather year (TMY) data for each location are shown in Table B-1; note the civic center tape represents Los Angeles. The residential and commercial average prices of energy for electricity and gas are in Table B-2.

Table B-1. Weather tapes used for DOE-2 simulations and typical weather year (TMY) data of 11 Metropolitan Statistical Areas (latent enthalpy hours: Btuh/lb of dry air).

\begin{tabular}{|c|c|c|c|c|c|c|c|}
\hline \multirow{3}{*}{ metropolitan area } & \multicolumn{5}{|c|}{ DOE-2 weather data } & \multicolumn{2}{|c|}{ TMY weather data } \\
\hline & \multirow[t]{2}{*}{ type } & \multirow{2}{*}{$\begin{array}{c}\text { latitude } \\
{ }^{\circ} \mathrm{N}\end{array}$} & \multirow[t]{2}{*}{$\begin{array}{l}\text { longitude } \\
{ }^{\circ} \mathrm{W}\end{array}$} & \multicolumn{2}{|c|}{$\begin{array}{c}\text { degree hours / } 24 \\
\text { at base } 65^{\circ} \mathrm{F}\end{array}$} & \multirow{2}{*}{$\begin{array}{c}\text { latent } \\
\text { enthalpy } \\
\text { hours }\end{array}$} & \multirow{2}{*}{$\begin{array}{l}\text { avg } \\
\text { sky } \\
\text { cover }\end{array}$} \\
\hline & & & & heating & cooling & & \\
\hline Atlanta & wyec2 & 33.65 & 84.42 & 3215 & 1602 & 4931 & 0.495 \\
\hline Chicago & wyec2 & 41.78 & 92.75 & 6425 & 1105 & 2781 & 0.492 \\
\hline Los Angeles & tmy (civic center) & 34.20 & 117.20 & 2238 & 1198 & 109 & 0.588 \\
\hline Dallas/Ft Wth & wyec2 (Ft Worth) & 32.90 & 97.03 & 2604 & 2649 & 7951 & 0.536 \\
\hline Houston & tmy & 29.65 & 95.28 & 1580 & 2883 & 18845 & 0.480 \\
\hline Miami/Ft Ldl & wyec2 (Miami) & 25.82 & 80.28 & 283 & 4011 & 27753 & 0.506 \\
\hline New Orleans & tmy & 29.88 & 90.25 & 1526 & 2610 & 17754 & 0.511 \\
\hline New York City & wyec2 & 40.77 & 73.90 & 5029 & 1076 & 1533 & 0.465 \\
\hline Philadelphia & tmy 2 & 39.88 & 75.25 & 5297 & 1146 & 3168 & 0.461 \\
\hline Phoenix & wyec2 & 33.43 & 112.02 & 1672 & 4044 & 967 & 0.686 \\
\hline DC/Baltimore & wyec (DC) & 38.95 & 77.45 & 4410 & 1494 & 3734 & 0.472 \\
\hline
\end{tabular}

Table B-2. Average 1993 prices of electricity and natural gas (EIA, 1993a and 1993b).

\begin{tabular}{|l||c|c||c|c|}
\hline \multirow{2}{*}{\multicolumn{1}{|c||}{ Metropolitan Area }} & \multicolumn{2}{c||}{ Electricity (cents/kWh) } & \multicolumn{2}{c|}{ Natural Gas (\$/MBtu) } \\
\cline { 2 - 5 } & Residential & Commercial & Residential & Commercial \\
\hline \hline Atlanta & 7.8 & 7.4 & 6.8 & 5.8 \\
Chicago & 11.2 & 8.4 & 5.5 & 5.1 \\
Los Angeles & 9.8 & 8.9 & 6.2 & 6.0 \\
Dallas/Fort Worth & 7.7 & 6.4 & 5.9 & 4.4 \\
Houston & 9.3 & 7.6 & 5.9 & 4.4 \\
Miami/Fort Lauderdale & 8.1 & 6.8 & 10.0 & 5.8 \\
New Orleans & 7.9 & 8.4 & 6.1 & 5.3 \\
New York City & 16.0 & 12.6 & 8.1 & 6.2 \\
Philadelphia & 12.8 & 11.8 & 6.8 & 6.0 \\
Phoenix & 10.7 & 9.2 & 7.2 & 5.1 \\
DC/Baltimore & 7.2 & 7.1 & 8.3 & 5.8 \\
\hline
\end{tabular}




\section{DOE-2 Building Prototype Characteristics and Simulation Results}

DOE-2 prototypes were developed for single-family residential and commercial buildings from several sources. Residential, office, and retail store prototype characteristics were based on survey data from the California Energy Commission (CEC, 1994). Additional residential characteristics were obtained from data of a Sacramento, California white-surface study (Akbari, et al., 1992). The primary and secondary schools, hospital, nursing home, and grocery store building prototypes and additional office and retail store characteristics were obtained from mail and onsite surveys of Pacific Gas \& Electric (PG\&E) and Southern California Edison (SCE) service areas during previous LBNL projects (Akbari, et al., 1989, 1991, and 1993b). These are shown in Tables B-3 through B-18.

The residential, office, and retail store prototypes were further sub-divided into old and new vintages and into gas furnace and electric heat pump heating types. The old style vintage represents pre-1980 construction practices and HVAC system efficiencies, and the new represents 1980 and later. In California, title-24 building energy standards were implemented starting 1978, and these were applied to the residential, office, and retail store new vintage prototypes. Construction, interior load, and HVAC system characteristics are shown for all building prototypes in Tables B-3 through B-18. The characteristics were uniform over all locations with the exception of the HVAC component sizes, which were locally dependent.

All buildings were modeled as single-story structures, with the exception of the 7 story hospital and the two-section secondary school (where the first section had 3 floors and the second 1 floor). The hospital had $14 \%$ roof area and the secondary school $57 \%$.

The prototypes were used as input to the building energy simulation program DOE-2.1E. These simulation results for the base case and savings from modified albedo are shown in Table B-19 for each building and location and are expressed per $1000 \mathrm{ft}^{2}$ of flat roof area.

DOE-2 Simulated HVAC Electricity, Natural Gas, and Net Energy Savings by Climate

Figures B-1 through B-4 are scatter plots of annual electricity, net energy, and peak demand savings in increasing order of cooling degree days, and annual natural gas deficit in increasing order of heating degree days for each building type and location. 
Table B-3. Single-family residential prototype characteristics.

\begin{tabular}{|c|c|c|}
\hline Characteristic & Old Vintage & New Vintage \\
\hline \multicolumn{3}{|l|}{ Construction } \\
\hline Floor Area $\left(\mathrm{ft}^{2}\right)$ & 1500 & \\
\hline Number of Floors & 1 & \\
\hline Floor Materials & Carpet w/ Pad & \\
\hline \multirow{2}{*}{ Roof Materials } & $\begin{array}{l}\text { 4" Heavy Weight Dried Concrete } \\
\text { 1/4" Asphalt Shingle 1/2" Plywood Attic Res }\end{array}$ & \\
\hline & $\begin{array}{r}\text { R-11 Insulation } \\
1 / 2 \text { "Gypsum }\end{array}$ & R-19 Insulation \\
\hline \multirow[t]{2}{*}{ Wall Materials } & 1" Stucco, Paper & \\
\hline & $\begin{array}{l}\text { R-7 Insulation } \\
\text { 1/2" Gypsum }\end{array}$ & R-11 Insulation \\
\hline Window Characteristics & Clear & \\
\hline Number of Panes & 1 & 2 \\
\hline Shading Coefficient & 0.86 & 0.76 \\
\hline \multicolumn{3}{|l|}{ Interior Loads } \\
\hline Occupancy & 3 & \\
\hline Interior Lights $\left(\mathrm{W} / \mathrm{ft}^{2}\right)$ & 0.4 & \\
\hline Miscellaneous $\left(\mathrm{W} / \mathrm{ft}^{2}\right)$ & 0.8 & \\
\hline \multicolumn{3}{|l|}{ HVAC System } \\
\hline Type & RESYS2 & \\
\hline Schedule. & $7 \mathrm{am}-11 \mathrm{pm}$ & \\
\hline & $\begin{array}{r}\text { Weekday / Weekend } \\
\text { Jan } 1 \text { - Dec } 31\end{array}$ & \\
\hline \multicolumn{3}{|l|}{ Ventilation } \\
\hline Capacity (cfm) & Local & Local \\
\hline Efficiency (W/cfm) & 0.373 & 0.336 \\
\hline Economizer & Enthalpic & \\
\hline Minimum Outside Air & 0.05 & \\
\hline Natural Ventilation & Yes & \\
\hline \multicolumn{3}{|l|}{ Cooling } \\
\hline Type & Packaged Direct-Expansion / Air-Cooled & \\
\hline Capacity (tons) & Local & Local \\
\hline COP & 2.1 & 2.7 \\
\hline Setpoint $\left({ }^{\circ} \mathrm{F}\right)$ & 78 & \\
\hline $\operatorname{Setup}\left({ }^{\circ} \mathrm{F}\right)$ & 78 & \\
\hline \multicolumn{3}{|l|}{ Heating } \\
\hline Type 1 & Forced Air / Natural Gas & \\
\hline Capacity (kBtu/hr) & Local & Local \\
\hline Efficiency (\%) & 70 & 74 \\
\hline Type 2 & Electric Heat Pump & \\
\hline Capacity (tons) & Local & Local \\
\hline COP & 2.1 & 2.7 \\
\hline Setpoint $\left({ }^{\circ} \mathrm{F}\right)$ & 70 & \\
\hline Setback $\left({ }^{\circ} \mathrm{F}\right)$ & 64 & \\
\hline
\end{tabular}


Table B-4. Single-family residential prototype local HVAC capacities.

\begin{tabular}{|l||c|c|c||c|c|c|}
\hline \multicolumn{1}{|c||}{ Location } & \multicolumn{3}{c||}{ Old Vintage } & \multicolumn{3}{c|}{ New Vintage } \\
\cline { 2 - 6 } & $\begin{array}{c}\text { Fan } \\
\text { (cfm) }\end{array}$ & $\begin{array}{c}\text { Cooling } \\
\text { (tons) }\end{array}$ & $\begin{array}{c}\text { Heating } \\
\text { (kBtu/hr) }\end{array}$ & $\begin{array}{c}\text { Fan } \\
\text { (cfm) }\end{array}$ & $\begin{array}{c}\text { Cooling } \\
\text { (tons) }\end{array}$ & $\begin{array}{c}\text { Heating } \\
\text { (kBtu/hr) }\end{array}$ \\
\hline \hline Atlanta & 800 & 2.5 & 40 & 700 & 2.0 & 35 \\
Chicago & 1000 & 2.5 & 50 & 800 & 2.0 & 35 \\
Los Angeles & 1000 & 2.5 & 45 & 900 & 2.0 & 40 \\
Fort Worth & 1100 & 3.0 & 50 & 900 & 2.5 & 40 \\
Houston & 900 & 3.0 & 45 & 800 & 2.5 & 35 \\
Miami & 900 & 2.5 & 40 & 800 & 2.0 & 35 \\
New Orleans & 800 & 2.0 & 40 & 600 & 2.0 & 30 \\
New York City & 900 & 2.5 & 45 & 700 & 2.0 & 35 \\
Philadelphia & 1000 & 2.5 & 50 & 900 & 2.0 & 40 \\
Phoenix & 1400 & 3.5 & 65 & 1200 & 3.0 & 55 \\
Washington DC & 800 & 2.5 & 40 & 700 & 2.0 & 35 \\
\hline
\end{tabular}


Table B-5. Office prototype characteristics.

\begin{tabular}{|c|c|c|}
\hline Characteristic & Old Vintage & New Vintage \\
\hline \multicolumn{3}{|l|}{ Construction } \\
\hline Floor Area $\left(\mathrm{ft}^{2}\right)$ & 4900 & \\
\hline Number of Floors & & \\
\hline Floor Materials & Carpet w/ Pad & \\
\hline \multirow[t]{2}{*}{ Roof Materials } & $\begin{array}{l}\text { 4" Heavy Weight Dried Concrete } \\
\text { Built-up-roof, 1/2" Plywood, Attic Res }\end{array}$ & \\
\hline & $\begin{array}{r}\text { R-11 Insulation } \\
1 / 2^{\prime \prime} \text { Gypsum }\end{array}$ & R-19 Insulation \\
\hline \multirow[t]{2}{*}{ Wall Materials } & 1" Stucco, 1/2" Plywood, Paper & \\
\hline & $\begin{array}{r}\text { R-7 Insulation } \\
\text { 1/2" Gypsum }\end{array}$ & R-11 Insulation \\
\hline Window Characteristics & Clear & \\
\hline Number of Panes & & \\
\hline Shading Coefficient & 0.86 & 0.76 \\
\hline Interior Loads & & \\
\hline Occupancy $\left(\mathrm{ft}^{2} /\right.$ person) & 200 & \\
\hline Interior Lights (W/ft $\left.{ }^{2}\right)$ & 1.4 & \\
\hline Miscellaneous $\left(\mathrm{W} / \mathrm{ft}^{2}\right)$ & 0.7 & \\
\hline \multicolumn{2}{|l|}{ HVAC System } & \\
\hline Schedule & $\begin{array}{r}6 \text { am }-7 \text { pm } \\
\text { Weekdays Only }\end{array}$ & \\
\hline & $\operatorname{Jan} 1-\operatorname{Dec} 31$ & \\
\hline Ventilation & Supply & \\
\hline Capacity (cfm) & Zonal/Local & Zonal/Local \\
\hline Efficiency $(\mathrm{W} / \mathrm{cfm})$ & 0.587 & 0.528 \\
\hline Economizer & Enthalpic & \\
\hline Outside Air ( $\mathrm{cfm} /$ person) & 15 & \\
\hline Natural Ventilation & No & \\
\hline \multicolumn{3}{|l|}{ Cooling } \\
\hline Type & Packaged Direct-Expansion / Air-Cooled & \\
\hline Capacity (tons) & Zonal/Local & Zonal/Local \\
\hline COP & 2.1 & 2.7 \\
\hline Setpoint $\left({ }^{\circ} \mathrm{F}\right)$ & 78 & \\
\hline $\begin{array}{l}\text { Setup }\left({ }^{\circ} F\right) \\
\text { Heating }\end{array}$ & 99 & \\
\hline \multicolumn{3}{|l|}{ Heating } \\
\hline Capacity $(\mathrm{kBtu} / \mathrm{hr})$ & Zonal/Local & Zonal/Local \\
\hline Efficiency (\%) & 70 & 74 \\
\hline Type 2 & Electric Heat Pump & \\
\hline Capacity (tons) & Zonal/Local & Zonal/Local \\
\hline COP & 2.1 & 2.7 \\
\hline Setpoint $\left({ }^{\circ} \mathrm{F}\right)$ & 70 & \\
\hline Setback $\left({ }^{\circ} \mathrm{F}\right)$ & 55 & \\
\hline
\end{tabular}


Table B-6. Office prototype zonal and local HVAC capacities.

\begin{tabular}{|c|c|c|c|c|c|c|c|c|c|c|c|c|c|c|c|}
\hline \multirow{3}{*}{ Location } & \multicolumn{15}{|c|}{ Old Office Zone } \\
\hline & \multicolumn{3}{|c|}{ Core $\left(1600 \mathrm{ft}^{2}\right)$} & \multicolumn{3}{|c|}{ North $\left(600 \mathrm{ft}^{2}\right)$} & \multicolumn{3}{|c|}{ East $\left(1050 \mathrm{ft}^{2}\right)$} & \multicolumn{3}{|c|}{ South $\left(600 \mathrm{ft}^{2}\right)$} & \multicolumn{3}{|c|}{ West $\left(1050 \mathrm{ft}^{2}\right)$} \\
\hline & $\begin{array}{c}\text { Fan } \\
\text { (cfm) }\end{array}$ & $\begin{array}{l}\text { Cooling } \\
\text { (tons) }\end{array}$ & $\begin{array}{l}\text { Heating } \\
\text { (kBtu/hr) }\end{array}$ & $\begin{array}{l}\text { Fan } \\
\text { (cfm) }\end{array}$ & $\begin{array}{l}\text { Cooling } \\
\text { (tons) }\end{array}$ & $\begin{array}{c}\text { Heating } \\
(\mathrm{kBtu} / \mathrm{hr})\end{array}$ & $\begin{array}{l}\text { Fan } \\
\text { (cfm) }\end{array}$ & $\begin{array}{l}\text { Cooling } \\
\text { (tons) }\end{array}$ & $\begin{array}{c}\text { Heating } \\
(\mathrm{kBtu} / \mathrm{hr})\end{array}$ & $\begin{array}{l}\text { Pan } \\
\text { (cfm) }\end{array}$ & $\begin{array}{c}\text { Cooling } \\
\text { (tons) }\end{array}$ & $\begin{array}{c}\text { Heating } \\
\text { (kBtu/hr) }\end{array}$ & $\begin{array}{c}\text { Fan } \\
(\mathrm{cfm})\end{array}$ & $\begin{array}{c}\text { Cooling } \\
\text { (tons) }\end{array}$ & $\begin{array}{l}\text { Heating } \\
\text { (kBtu/hr) }\end{array}$ \\
\hline Atlanta & 800 & 2.5 & 40 & 540 & 2.0 & 30 & 945 & 2.5 & 40 & 780 & 2.5 & 40 & 945 & $\overline{2.5}$ & $\overline{40}$ \\
\hline Chicago & 800 & 2.5 & 40 & 540 & $2.0^{\circ}$ & 30 & 945 & 2.5 & 45 & 720 & 2.0 & 35 & 945 & 2.5 & 45 \\
\hline Los Angeles & 800 & 2.5 & 35 & 540 & 2.0 & 25 & 945 & 2.5 & 40 & 1020 & 3.0 & 45 & 945 & 2.5 & 40 \\
\hline Fort Worth & 960 & 3.0 & 45 & 619 & 2.5 & 30 & 1050 & 3.0 & 45 & 781 & 2.5 & 40 & 1050 & 3.5 & 50 \\
\hline Houston & 800 & 3.0 & 35 & 544 & 2.0 & 30 & 945 & 3.0 & 40 & 780 & 2.5 & 35 & 945 & 3.0 & 40 \\
\hline Miami & 800 & 3.0 & 40 & 540 & 2.0 & 25 & 945 & 3.0 & 40 & 900 & 3.0 & 40 & 945 & 3.0 & 40 \\
\hline New Orleans & 800 & 3.0 & 35 & 540 & 2.0 & 25 & 945 & 3.0 & 40 & 780 & 2.5 & 35 & 945 & 3.0 & 40. \\
\hline New York City & 800 & 2.5 & 35 & 600 & 2.0 & 30 & 1050 & 3.0 & 45 & 600 & 2.0 & 30 & 1050 & 2.5 & 40 \\
\hline Philadelphia & 800 & 2.5 & 40 & 540 & 1.5 & 30 & 945 & 2.5 & 40 & 600 & 2.0 & 30 & 945 & 2.5 & 40 \\
\hline Phoenix & 968 & 3.0 & 45 & 731 & 2.5 & 35 & 1260 & 3.5 & 50 & 960 & 3.0 & 45 & 1260 & 3.5 & 55 \\
\hline Washington $D C$ & 800 & 2.5 & 35 & 540 & 2.0 & 30 & 945 & 2.5 & 40 & 660 & 2.5 & 35 & 945 & 3.0 & 45 \\
\hline
\end{tabular}

\begin{tabular}{|c|c|c|c|c|c|c|c|c|c|c|c|c|c|c|c|}
\hline \multirow{3}{*}{ Location } & \multicolumn{15}{|c|}{ New Office Zone } \\
\hline & \multicolumn{3}{|c|}{ Core $\left(1600 \mathrm{ft}^{2}\right)$} & \multicolumn{3}{|c|}{ North $\left(600 \mathrm{ft}^{2}\right)$} & \multicolumn{3}{|c|}{ East $\left(1050 \mathrm{ft}^{2}\right)$} & \multicolumn{3}{|c|}{ South $\left(600 \mathrm{ft}^{2}\right)$} & \multicolumn{3}{|c|}{ West $\left(1050 \mathrm{ft}^{2}\right)$} \\
\hline & $\begin{array}{c}\text { Fan } \\
(\mathrm{cfm})\end{array}$ & $\begin{array}{c}\text { Cooling } \\
\text { (tons) }\end{array}$ & $\begin{array}{l}\text { Heating } \\
(\mathrm{kBtw} / \mathrm{hr})\end{array}$ & $\begin{array}{c}\text { Fan } \\
(\mathrm{cfm})\end{array}$ & $\begin{array}{c}\text { Cooling } \\
\text { (tons) }\end{array}$ & $\begin{array}{c}\text { Heating } \\
\text { (kBtu/hr) }\end{array}$ & $\begin{array}{c}\text { Fan } \\
(\mathrm{cfm})\end{array}$ & $\begin{array}{c}\text { Cooling } \\
\text { (tons) }\end{array}$ & $\begin{array}{c}\text { Heating } \\
\text { (kBtu/hr) }\end{array}$ & $\begin{array}{c}\text { Fan } \\
\text { (cfm) }\end{array}$ & $\begin{array}{c}\text { Cooling } \\
\text { (tons) }\end{array}$ & $\begin{array}{c}\text { Heating } \\
\text { (kBtu/hr) }\end{array}$ & $\begin{array}{c}\text { Fan } \\
(\mathrm{cfm})\end{array}$ & $\begin{array}{c}\text { Cooling } \\
\text { (tons) }\end{array}$ & $\begin{array}{l}\text { Heating } \\
\text { (kBtu/hr) }\end{array}$ \\
\hline Atlanta & 800 & 2.5 & 35 & 422 & 1.5 & 25 & 735 & 2.5 & 35 & 720 & 2.5 & 35 & 735 & 2.5 & 35 \\
\hline Chicago & 800 & 2.5 & 35 & 480 & 1.5 & 25 & 840 & 2.5 & 40 & 660 & 2.0 & 35 & 840 & 2.5 & 40 \\
\hline Los Angeles & 800 & 2.5 & 30 & 480 & 1.5 & 20 & 840 & 2.5 & 35 & 900 & 2.5 & 40 & 840 & 2.5 & 35 \\
\hline Fort Worth & 960 & 3.0 & 40 & 540 & 2.0 & 30 & 945 & 3.0 & 40 & 720 & 2.5 & 35 & 945 & 3.0 & 40 \\
\hline Houston & 800 & 2.5 & 35 & 480 & 2.0 & 25 & 840 & 2.5 & 35 & 660 & 2.5 & 35 & 840 & 3.0 & 35 \\
\hline Miami & 800 & 2.5 & 35 & 480 & 2.0 & 25 & 840 & 2.5 & 35 & 780 & 2.5 & 35 & 840 & 2.5 & 35 \\
\hline New Orleans & 800 & 2.5 & 35 & 427 & 2.0 & 25 & 735 & 2.5 & 35 & 663 & 2.5 & 35 & 735 & 2.5 & 35 \\
\hline New York City & 800 & 2.0 & 35 & 480 & 1.5 & 25 & 840 & 2.5 & 40 & 540 & 1.5 & 25 & 840 & 2.5 & 35 \\
\hline Philadelphia & 800 & 2.5 & 40 & 420 & 1.5 & 25 & 735 & 2.0 & 35 & 540 & 2.0 & 30 & 735 & 2.0 & 35 \\
\hline Phoenix & 960 & 3.0 & 40 & 600 & 2.0 & 30 & 1050 & 3.0 & 40 & 840 & 2.5 & 40 & 1050 & 3.0 & 45 \\
\hline Washington DC & 800 & 2.5 & 35 & 480 & 1.5 & 25 & 840 & 2.5 & 35 & 600 & 2.0 & 30 & 840 & 2.5 & 40 \\
\hline
\end{tabular}


Table B-7. Retail store prototype characteristics.

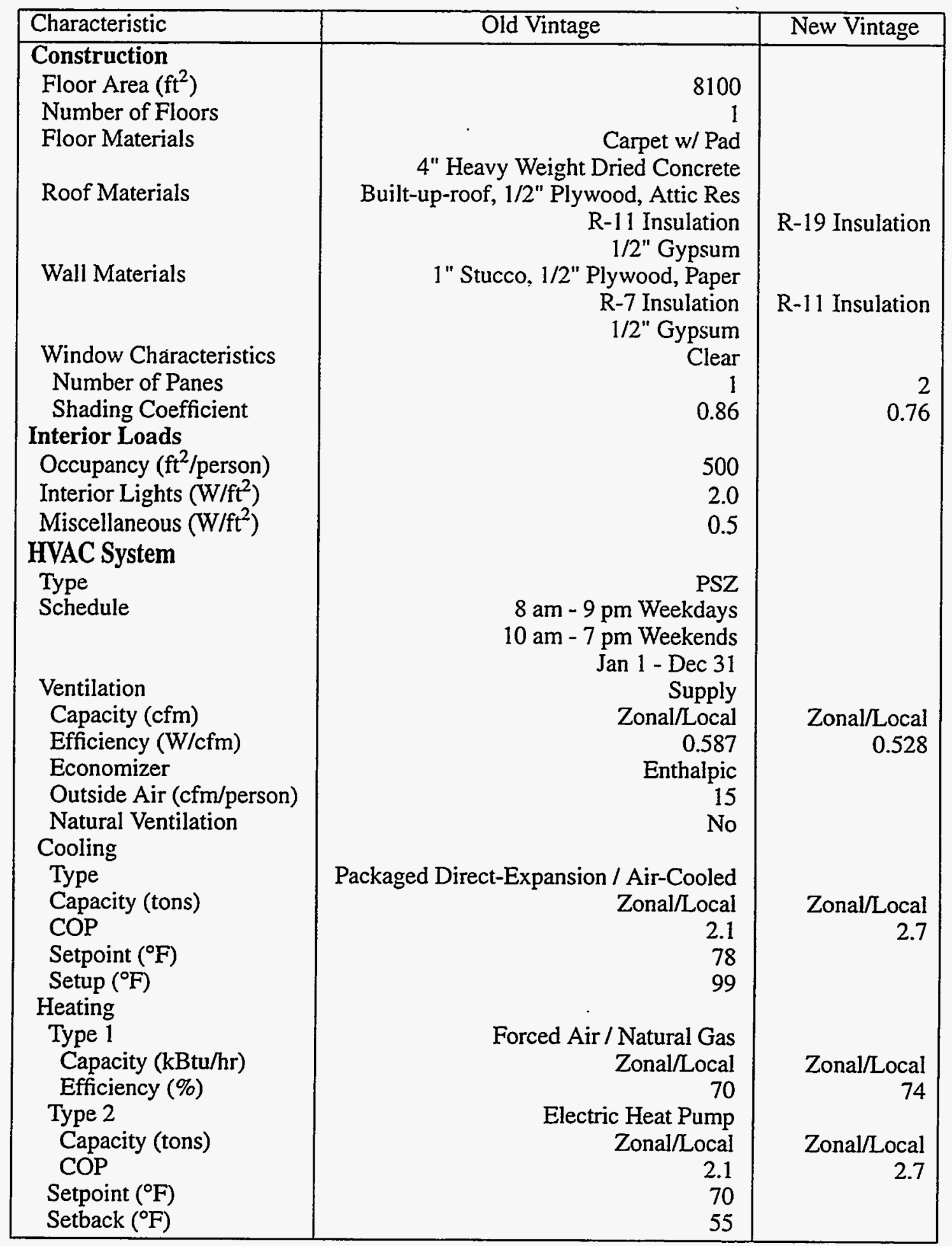


Table B-8. Retail store prototype local HVAC capacities.

\begin{tabular}{|l||c|c|c||c|c|c|}
\hline \multicolumn{1}{|c||}{ Location } & \multicolumn{3}{c||}{ Old Vintage } & \multicolumn{3}{c|}{ New Vintage } \\
\cline { 2 - 7 } & $\begin{array}{c}\text { Fan } \\
\text { (cfm) }\end{array}$ & $\begin{array}{c}\text { Cooling } \\
\text { (tons) }\end{array}$ & $\begin{array}{c}\text { Heating } \\
\text { (kBtu/hr) }\end{array}$ & $\begin{array}{c}\text { Fan } \\
\text { (cfm) }\end{array}$ & $\begin{array}{c}\text { Cooling } \\
\text { (tons) }\end{array}$ & $\begin{array}{c}\text { Heating } \\
\text { (kBtu/hr) }\end{array}$ \\
\hline \hline Atlanta & 5670 & 15.0 & 250 & 4860 & 15.0 & 220 \\
Chicago & 5670 & 15.0 & 240 & 4860 & 12.5 & 210 \\
Los Angeles & 5670 & 15.0 & 240 & 4860 & 12.5 & 210 \\
Fort Worth & 6480 & 20.0 & 270 & 5670 & 15.0 & 230 \\
Houston & 5670 & 15.0 & 240 & 4860 & 15.0 & 210 \\
Miami & 5670 & 15.0 & 240 & 4860 & 15.0 & 210 \\
New Orleans & 5670 & 15.0 & 240 & 4860 & 15.0 & 210 \\
New York City & 5670 & 15.0 & 240 & 4860 & 12.5 & 210 \\
Philadelphia & 5670 & 15.0 & 230 & 4860 & 12.5 & 200 \\
Phoenix & 7290 & 20.0 & 290 & 5670 & 20.0 & 250 \\
Washington DC & 5670 & 15.0 & 250 & 4860 & 15.0 & 220 \\
\hline
\end{tabular}


Table B-9. Primary school prototype characteristics.

\begin{tabular}{|c|c|}
\hline Construction & \\
\hline $\begin{array}{l}\text { Construction } \\
\text { Floor Area }\left(\mathrm{ft}^{2}\right)\end{array}$ & 35000 \\
\hline Number of Floors & 1 \\
\hline Floor Materials & Linoleum Tile \\
\hline Roof Materials & $\begin{array}{l}\text { 6" Heavy Weight Dried Concrete } \\
\text { Built-up-roof, 1/2" Plywood, Attic Res }\end{array}$ \\
\hline & $\begin{array}{r}\text { R-11 Insulation } \\
1 / 2^{\prime \prime} \text { Gypsum }\end{array}$ \\
\hline Wall Materials & $\begin{array}{r}\text { 8" Medium Concrete Block Hollow } \\
\text { R-7 Insulation }\end{array}$ \\
\hline & 1/2" Gypsum \\
\hline Window Characteristics & Clear \\
\hline Numb & \\
\hline Shading Coefficient & 0.86 \\
\hline Interior & \\
\hline Occupa & Zonal \\
\hline Interior Lights (W/ft $\left.{ }^{2}\right)$ & Zonal \\
\hline Miscellaneous $\left(\mathrm{W} / \mathrm{ft}^{2}\right)$ & Zonal \\
\hline HVAC System & \\
\hline Type & PSZ \\
\hline Schedule & $7 \mathrm{am}-6 \mathrm{pm}$ \\
\hline & $\begin{array}{r}\text { Weekday Only } \\
\operatorname{Jan} 1 \text { - Jun } 13, \operatorname{Sep} 2-\operatorname{Dec} 23\end{array}$ \\
\hline Ventila & Supply \\
\hline Capa & Zonal/Local \\
\hline W/cfm) & 0.587 \\
\hline Economize & Enthalpic \\
\hline Outsi & Zonal \\
\hline Natural Ventilatic & No \\
\hline Cooling & \\
\hline Type & Packaged Direct-Expansion / Air-Cooled \\
\hline city (tons) & Zonal/Local \\
\hline $\mathrm{CO}$ & 2.1 \\
\hline int $\left({ }^{\circ} \mathrm{F}\right)$ & 74 \\
\hline Setup $\left({ }^{\circ} F\right)$ & 99 \\
\hline Heating & \\
\hline Type & Forced Air / Natural Gas \\
\hline acity $(\mathrm{kBtu} / \mathrm{hr})$ & Zonal/Local \\
\hline \%) & 70 \\
\hline & 71 \\
\hline Setback $\left({ }^{\circ} \mathrm{F}\right)$ & 55 \\
\hline
\end{tabular}

\begin{tabular}{|l|r|r|r|r|}
\hline & Class & Kitchen & Library & Total \\
\hline Floor Area (\% of total) & 77 & 6 & 17 & 100 \\
Occupancy (ft ${ }^{2} /$ person) & 90 & 210 & 80 & - \\
Outside Air (cfm/person) & 15 & - & 15 & - \\
Outside Air (ach) & - & 2.9 & - & - \\
Interior Lights (W/ft ${ }^{2}$ ) & 1.8 & 1.4 & 1.2 & 1.7 \\
Miscellaneous (W/ $/ \mathrm{ft}^{2}$ ) & 0.5 & 11.7 & 0.5 & 1.2 \\
\hline
\end{tabular}


Table B-10. Primary school prototype zonal and local HVAC capacities.

\begin{tabular}{|c|c|c|c|c|c|c|c|c|c|}
\hline \multirow{3}{*}{ Location } & \multicolumn{9}{|c|}{ Zone } \\
\hline & \multicolumn{3}{|c|}{ Class } & \multicolumn{3}{|c|}{ Kitchen } & \multicolumn{3}{|c|}{ Library } \\
\hline & $\begin{array}{c}\text { Fan } \\
(\mathrm{cfm}) \\
\end{array}$ & $\begin{array}{c}\text { Cooling } \\
\text { (tons) }\end{array}$ & $\begin{array}{c}\text { Heating } \\
(\mathrm{kBtu} / \mathrm{hr})\end{array}$ & $\begin{array}{c}\text { Fan } \\
(\mathrm{cfm}) \\
\end{array}$ & $\begin{array}{c}\text { Cooling } \\
\text { (tons) } \\
\end{array}$ & $\begin{array}{c}\text { Heating } \\
(\mathrm{kBtu} / \mathrm{hr})\end{array}$ & $\begin{array}{c}\text { Fan } \\
(\mathrm{cfm}) \\
\end{array}$ & $\begin{array}{c}\text { Cooling } \\
\text { (tons) }\end{array}$ & $\begin{array}{c}\text { Heating } \\
(\mathrm{kBtu} / \mathrm{hr})\end{array}$ \\
\hline Atlanta & 27000 & 75 & 1400 & 4401 & 15 & 250 & 4798 & 15 & 300 \\
\hline Chicago & 27000 & 75 & 1500 & 4399 & 15 & 300 & 4437 & 15 & 300 \\
\hline Los Angeles & 27366 & 75 & 1300 & 4426 & 15 & 250 & 4798 & 15 & 250 \\
\hline Fort Worth & 29700 & 85 & 1500 & 4398 & 20 & 250 & 4848 & 20 & 300 \\
\hline Houston & 27000 & 80 & 1300 & 4440 & 20 & 250 & 4311 & 15 & 250 \\
\hline Miami & 27388 & 80 & 1300 & 4478 & 20 & 250 & 4814 & 20 & 250 \\
\hline New Orleans & 27000 & 85 & 1300 & 4463 & 20 & 250 & 4435 & 20 & 250 \\
\hline New York City & 24300 & 65 & 1300 & 4398 & 15 & 250 & 3895 & 15 & 250 \\
\hline Philadelphia & 21695 & 55 & 1200 & 4398 & 15 & 250 & 3284 & 10 & 250 \\
\hline Phoenix & 33331 & 85 & 1600 & 4621 & 20 & 250 & 5998 & 20 & 250 \\
\hline Washington DC & 27000 & 75 & 1400 & 4300 & 15 & 250 & 4322 & 15 & 250 \\
\hline
\end{tabular}


Table B-11. Secondary school prototype characteristics.

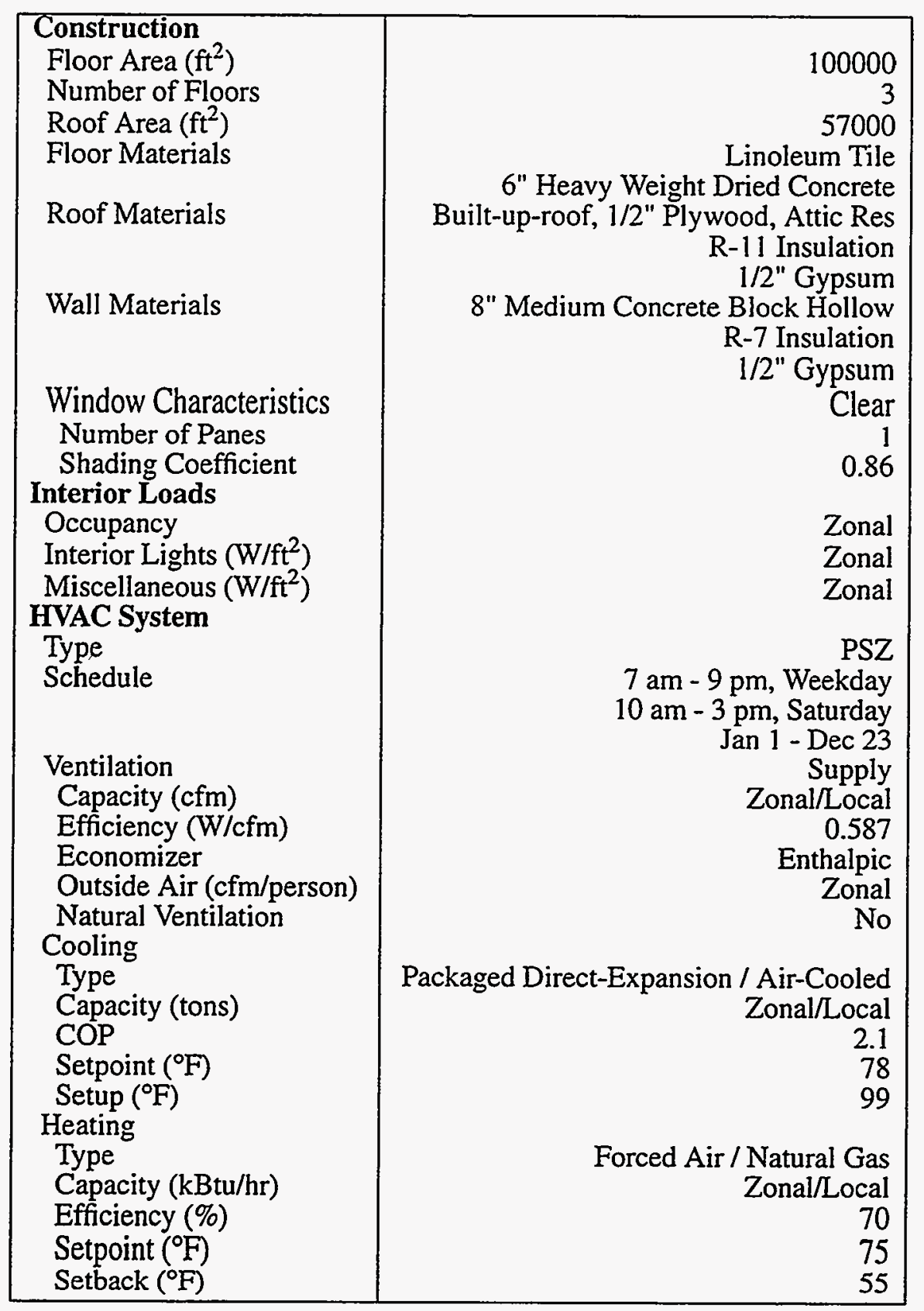

\begin{tabular}{|l|r|r|r|r|r|r|r|}
\hline & Library & Gym & Auditorium & Kitchen & Dining & Class & Total \\
\hline Floor Area (\% of total) & 13 & 13 & 8 & 2 & 4 & 60 & 100 \\
Occupancy (ft ${ }^{2}$ /person) & 100 & 180 & 100 & 300 & 20 & 90 & - \\
Outside Air (cfm/person) & 15 & 15 & 15 & - & 15 & 15 & - \\
Outside Air (ach) & - & - & - & 3.0 & - & - & - \\
Interior Lights (W/ft' & 1.5 & 0.7 & 0.8 & 1.7 & 1.7 & 2.2 & 1.8 \\
Miscellaneous (W/ $\mathrm{ft}^{2}$ ) & 0.15 & 0.15 & 0.15 & 12.0 & 0.15 & 0.15 & 0.4 \\
\hline
\end{tabular}


Table B-12. Secondary school prototype zonal and local HVAC capacities.

\begin{tabular}{|c|c|c|c|c|c|c|c|c|c|c|c|c|c|c|c|}
\hline \multirow{3}{*}{ Location } & \multicolumn{15}{|c|}{ Zone } \\
\hline & \multicolumn{3}{|c|}{ Library } & \multicolumn{3}{|c|}{ Gym } & \multicolumn{3}{|c|}{ Auditorium } & \multicolumn{3}{|c|}{ Kitchen } & \multicolumn{3}{|c|}{ Dining } \\
\hline & $\begin{array}{c}\text { Fan } \\
(\mathrm{cfm})\end{array}$ & $\begin{array}{c}\text { Cooling } \\
\text { (tons) }\end{array}$ & $\begin{array}{l}\text { Heating } \\
\text { (kBtu/hr) }\end{array}$ & $\begin{array}{c}\text { Fan } \\
(\mathrm{cfm})\end{array}$ & $\begin{array}{c}\text { Cooling } \\
\text { (tons) }\end{array}$ & $\begin{array}{l}\text { Heating } \\
\text { (kBtu/hr) }\end{array}$ & $\begin{array}{c}\text { Fan } \\
(\mathrm{cfm})\end{array}$ & $\begin{array}{c}\text { Cooling } \\
\text { (tons) }\end{array}$ & $\begin{array}{l}\text { Heating } \\
(\mathrm{kBtu} / \mathrm{hr})\end{array}$ & $\begin{array}{c}\text { Fan } \\
(\mathrm{cfm})\end{array}$ & $\begin{array}{c}\text { Cooling } \\
\text { (tons) }\end{array}$ & $\begin{array}{l}\text { Heating } \\
(\mathrm{kBtu} / \mathrm{hr})\end{array}$ & $\begin{array}{c}\text { Fan } \\
(\mathrm{cfm})\end{array}$ & $\begin{array}{c}\text { Cooling } \\
\text { (tons) }\end{array}$ & $\begin{array}{l}\text { Heating } \\
(\mathrm{kBtu} / \mathrm{hr})\end{array}$ \\
\hline Atlanta & 5200 & 20 & 350 & 11700 & 35 & 500 & 6400 & 20 & 350 & 3600 & 15 & 200 & 4800 & 25 & 400 \\
\hline Chicago & 5200 & 20 & 350 & 15600 & 50 & 650 & 8361 & 30 & 400 & 3600 & 15 & 250 & 4918 & 25 & 450 \\
\hline Los Angeles & 5200 & 20 & 250 & 9100 & 30 & 350 & 3200 & 10 & 200 & 3600 & 12 & 200 & 5200 & 20 & 300 \\
\hline Fort Worth & 5200 & 25 & 350 & 10400 & 35 & 450 & 4932 & 20 & 300 & 3600 & 15 & 200 & 4932 & 25 & 400 \\
\hline Houston & 5200 & 25 & 300 & 9141 & 35 & 400 & 4202 & 20 & 250 & 3600 & 15 & 200 & 4827 & 25 & 350 \\
\hline Miami & 5200 & 25 & 300 & 9100 & 35 & 400 & 3200 & 15 & 200 & 3600 & 15 & 200 & 4935 & 25 & 350 \\
\hline New Orleans & 5200 & 20 & 300 & 9100 & 30 & 400 & 4108 & 20 & 250 & 3605 & 15 & 200 & 4868 & 25 & 350 \\
\hline New York City & 5200 & 20 & 350 & 14370 & 40 & 600 & 8000 & 25 & 400 & 3476 & 12 & 200 & 4868 & 20 & 400 \\
\hline Philadelphia & 4209 & 15 & 300 & 13000 & 35 & 550 & 7200 & 20 & 350 & 3463 & 12 & 200 & 4800 & 20 & 400 \\
\hline Phoenix & 5203 & 25 & 300 & 15976 & 50 & 650 & 7200 & 25 & 350 & 3800 & 15 & 200 & 5600 & 25 & 400 \\
\hline Washington DC & 5200 & 20 & 300 & 12251 & 40 & 550 & 6400 & 25 & 350 & 3458 & 15 & 200 & 4800 & 25 & 400 \\
\hline
\end{tabular}

\begin{tabular}{|l||c|c|c||c|c|c|}
\hline \multicolumn{1}{|c||}{} & \multicolumn{5}{c|}{ Location } & \multicolumn{3}{c|}{ Class Bottom Floor } & \multicolumn{3}{c|}{ Class Top Floor } \\
\cline { 2 - 7 } & $\begin{array}{c}\text { Fan } \\
\text { (cfm) }\end{array}$ & $\begin{array}{c}\text { Cooling } \\
\text { (tons) }\end{array}$ & $\begin{array}{c}\text { Heating } \\
\text { (kBtu/hr) }\end{array}$ & $\begin{array}{c}\text { Fan } \\
\text { (cfm) }\end{array}$ & $\begin{array}{c}\text { Cooling } \\
\text { (tons) }\end{array}$ & $\begin{array}{c}\text { Heating } \\
\text { (kBtu/hr) }\end{array}$ \\
\hline \hline Atlanta & 17999 & 65 & 1000 & 22182 & 75 & 1150 \\
Chicago & 18092 & 65 & 1100 & 21859 & 75 & 1200 \\
Los Angeles & 18529 & 55 & 850 & 22238 & 65 & 1000 \\
Fort Worth & 20999 & 75 & 1050 & 23999 & 80 & 1150 \\
Houston & 17999 & 75 & 900 & 22335 & 85 & 1100 \\
Miami & 19447 & 75 & 950 & 23999 & 85 & 1050 \\
New Orleans & 17999 & 70 & 900 & 23999 & 80 & 1100 \\
New York City & 18129 & 60 & 1000 & 21640 & 65 & 1150 \\
Philadelphia & 17999 & 55 & 1000 & 20999 & 60 & 1100 \\
Phoenix & 21203 & 75 & 1050 & 26999 & 90 & 1250 \\
Washington DC & 17999 & 65 & 950 & 20999 & 75 & 1100 \\
\hline
\end{tabular}


Table B-13. Hospital prototype characteristics.

\begin{tabular}{|c|c|}
\hline Construction & \\
\hline Floor Area $\left(\mathrm{ft}^{2}\right)$ & 132000 \\
\hline Number of Floors & \\
\hline Roof Area $\left(\mathrm{ft}^{2}\right)$ & 18900 \\
\hline Floor Materials & $\begin{array}{r}\text { Carpet and Pad } \\
\text { 6" Heavy Weight Dried Concrete }\end{array}$ \\
\hline Roof Materials & $\begin{array}{r}\text { Built-up-roof, 6" Concrete Deck, Attic Res } \\
\text { R-11 Insulation } \\
\text { Acric Tile }\end{array}$ \\
\hline Wall Materials & $\begin{array}{r}\text { 12" Heavy Concrete Block Filled } \\
\text { R-7 Insulation } \\
\text { Air-Space, } 1 / 2 " \text { Gypsum }\end{array}$ \\
\hline $\begin{array}{l}\text { Window Characteristics } \\
\text { Number of Panes }\end{array}$ & Clear \\
\hline Shading Coefficient & 0.86 \\
\hline Interior Loads & \\
\hline Occupancy & Zonal \\
\hline Interior Lights (W/ $\left.\mathrm{ft}^{2}\right)$ & Zonal \\
\hline Miscellaneous $\left(\mathrm{W} / \mathrm{ft}^{2}\right)$ & Zonal \\
\hline HVAC System & \\
\hline Type & VAVS \\
\hline Schedule & $\begin{array}{r}24 \text { Hour Operation } \\
\text { Weekday / Weekend } \\
\text { Jan 1 - Dec 31 }\end{array}$ \\
\hline Ventilation & Supply \\
\hline Capacity (cfm) & Zonal/Local \\
\hline Economizer & Enthalpic \\
\hline Outside Air (cfm/person) & Zonal \\
\hline Natural Ventilation & No \\
\hline Cooling & \\
\hline Type & Hermetic Centrifugal Chiller / Air-Cooled Cooling Tower \\
\hline Capacity (tons) & Local \\
\hline Setpoint $\left({ }^{\circ} \mathrm{F}\right)$ & 78 \\
\hline Heating & \\
\hline Type & Hot Water Boiler / Natural Gas \\
\hline Capacity (MBtu/hr) & Local \\
\hline Setpoint $\left({ }^{\circ} \mathrm{F}\right)$ & 70 \\
\hline
\end{tabular}

\begin{tabular}{|l|r|r|r|r|r|r|}
\hline & Perimeter (Rooms) & Core/Public & Hallways & Kitchen & Clinic & Total \\
\hline Floor Area (\% total) & 15 & 35 & 20 & 5 & 25 & 100 \\
Occupancy (ft ${ }^{2} /$ person) & 150 & 290 & 580 & 320 & 290 & - \\
Outside Air (cfm/person) & 15 & 15 & 15 & - & 15 & - \\
Outside Air (ach) & - & - & - & 1.8 & - & - \\
Interior Lights (W/ft' & 1.6 & 1.6 & 0.8 & 2.1 & 2.1 & 1.6 \\
Miscellaneous (W/ft & 1.3 & - & 13.0 & 4.0 & 2.3 \\
\hline
\end{tabular}


Table B-14. Hospital prototype zonal and local HVAC capacities.

\begin{tabular}{|l||c|c|c|c|c|c|c|}
\hline \multicolumn{1}{|c||}{ Location } & \multicolumn{9}{c|}{ Zone } \\
\cline { 2 - 8 } & $\begin{array}{c}\text { Perimeter } \\
\text { (Rooms) }\end{array}$ & $\begin{array}{c}\text { Core/Public/ } \\
\text { Hallways }\end{array}$ & Kitchen & Clinic & \multicolumn{3}{c|}{ All Zones } \\
\cline { 2 - 8 } & $\begin{array}{c}\text { Fan } \\
\text { (cfm) }\end{array}$ & $\begin{array}{c}\text { Fan } \\
\text { (cfm) }\end{array}$ & $\begin{array}{c}\text { Fan } \\
\text { (cfm) }\end{array}$ & $\begin{array}{c}\text { Fan } \\
\text { (cfm) }\end{array}$ & $\begin{array}{c}\text { Chiller } \\
\text { (tons) }\end{array}$ & $\begin{array}{c}\text { Cooling Tower } \\
\text { (tons) }\end{array}$ & $\begin{array}{c}\text { Boiler } \\
\text { (MBtu/hr) }\end{array}$ \\
\hline \hline Atlanta & 43659 & 74327 & 15868 & 47297 & 450 & 550 & 1.57 \\
Chicago & 45560 & 75694 & 15891 & 47294 & 450 & 550 & 2.62 \\
Los Angeles & 47446 & 77303 & 15895 & 47458 & 450 & 550 & 0.23 \\
Fort Worth & 49657 & 82758 & 16560 & 50998 & 500 & 600 & 1.08 \\
Houston & 43995 & 74844 & 15876 & 47463 & 450 & 550 & 0.68 \\
Miami & 43509 & 73661 & 15331 & 47269 & 450 & 550 & 0.19 \\
New Orleans & 43584 & 73871 & 15350 & 47310 & 450 & 550 & 0.70 \\
New York City & 45487 & 75069 & 15422 & 47264 & 450 & 550 & 2.04 \\
Philadelphia & 45800 & 76290 & 15914 & 47490 & 450 & 550 & 1.82 \\
Phoenix & 55536 & 90892 & 17233 & 54537 & 500 & 600 & 0.41 \\
Washington DC & 45531 & 75548 & 15889 & 47401 & 450 & 550 & 1.78 \\
\hline
\end{tabular}


Table B-15. Nursing home prototype characteristics.

\begin{tabular}{|c|c|}
\hline Construction & \\
\hline Floor Area $\left(\mathrm{ft}^{2}\right)$ & 38400 \\
\hline Number of Floors & 1 \\
\hline Floor Materials & Carpet and Pad \\
\hline Roof Materials & $\begin{array}{l}\text { 6" Heavy Weight Dried Concrete } \\
\text { Built-up-roof, 1/2" Plywood, Attic Res }\end{array}$ \\
\hline & $\begin{array}{r}\text { R-11 Insulation } \\
\text { Acoustic Tile }\end{array}$ \\
\hline Wall Materials & $\begin{array}{r}\text { 8" Medium Concrete Block Hollow } \\
\text { R-7 Insulation } \\
1 / 2 " \text { Gypsum }\end{array}$ \\
\hline Window Characteristics & Clear \\
\hline Number of Panes & 1 \\
\hline Shading Coefficient & 0.86 \\
\hline Interior Loads & \\
\hline Occupancy & Zonal \\
\hline Interior Lights $\left(\mathrm{W} / \mathrm{ft}^{2}\right)$ & Zonal \\
\hline Miscellaneous $\left(\mathrm{W} / \mathrm{ft}^{2}\right)$ & Zonal \\
\hline HVAC System & \\
\hline Type & PSZ \\
\hline Schedule & $\begin{array}{r}24 \text { Hour Operation } \\
\text { Weekday / Weekend } \\
\text { Jan } 1 \text { - Dec } 31\end{array}$ \\
\hline Ventilation & Supply \\
\hline Capacity (cfm) & Zonal/Local \\
\hline Efficiency (W/cfm) & 0.587 \\
\hline Economizer & Enthalpic \\
\hline Outside Air (cfm/person) & Zonal \\
\hline Natural Ventilation & No \\
\hline Cooling & \\
\hline Type & Packaged Direct-Expansion / Air-Cooled \\
\hline Capacity (tons) & Zonal/Local \\
\hline COP & 2.1 \\
\hline Setpoint $\left({ }^{\circ} \mathrm{F}\right)$ & 78 \\
\hline Setup $\left({ }^{\circ} \mathrm{F}\right)$ & 99 \\
\hline Heating & \\
\hline Type & Forced Air / Natural Gas \\
\hline Capacity (kBtu/hr) & Zonal/Local \\
\hline Efficiency (\%) & 70 \\
\hline Setpoint $\left({ }^{\circ} \mathrm{F}\right)$ & 70 \\
\hline Setback ( $\left.{ }^{\circ} \mathrm{F}\right)$ & 55 \\
\hline
\end{tabular}

\begin{tabular}{|c|c|c|c|c|}
\hline & Multi-Purpose & Kitchen & Rooms & Total \\
\hline Floor & 20 & 5 & 75 & 100 \\
\hline Occupancy ( $\mathrm{ft}^{2} /$ person) & 50 & 190 & 300 & - \\
\hline Outside Air (cfm/person) & 15 & - & 15 & - \\
\hline Outside Air (ach) & 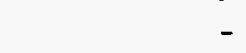 & 3.9 & & \\
\hline Interior Lights (W/ $\left.\mathrm{ft}^{2}\right)$ & 1.2 & 1.3 & 0.8 & 0.9 \\
\hline Miscellaneous (W/ft $\left.{ }^{2}\right)$ & & 18.0 & 1.3 & 1.9 \\
\hline
\end{tabular}


Table B-16. Nursing home prototype zonal and local HVAC capacities.

\begin{tabular}{|c|c|c|c|c|c|c|c|c|c|}
\hline \multirow{3}{*}{ Location } & \multicolumn{9}{|c|}{ Zone } \\
\hline & \multicolumn{3}{|c|}{ Multi-Purpose } & \multicolumn{3}{|c|}{ Kitchen } & \multicolumn{3}{|c|}{ Rooms } \\
\hline & $\begin{array}{c}\text { Fan } \\
(\mathrm{cfm})\end{array}$ & $\begin{array}{c}\text { Cooling } \\
\text { (tons) }\end{array}$ & $\begin{array}{l}\text { Heating } \\
\text { (kBtu/hr) }\end{array}$ & $\begin{array}{c}\text { Fan } \\
(\mathrm{cfm})\end{array}$ & $\begin{array}{c}\text { Cooling } \\
\text { (tons) }\end{array}$ & $\begin{array}{l}\text { Heating } \\
(\mathrm{kBtu} / \mathrm{hr})\end{array}$ & $\begin{array}{c}\text { Fan } \\
(\mathrm{cfm})\end{array}$ & $\begin{array}{c}\text { Cooling } \\
\text { (tons) }\end{array}$ & $\begin{array}{l}\text { Heating } \\
(\mathrm{kBtu} / \mathrm{hr})\end{array}$ \\
\hline Atlanta & 4603 & 20 & 350 & 2302 & 10 & 200 & 17844 & 50 & 850 \\
\hline Chicago & 4037 & 15 & 400 & 2302 & 8 & 200 & 17113 & 45 & 850 \\
\hline Los Angeles & 4603 & 20 & 300 & 2302 & 8 & 150 & 18401 & 50 & 800 \\
\hline Fort Worth & 4951 & 20 & 350 & 2327 & 10 & 150 & 19709 & 55 & 900 \\
\hline Houston & 3995 & 20 & 300 & 2302 & 10 & 150 & 16177 & 50 & 750 \\
\hline Miami & 4603 & 20 & 300 & 2302 & 9 & 150 & 18838 & 55 & 850 \\
\hline New Orleans & 3894 & 20 & 300 & 2302 & 9 & 150 & 16099 & 50 & 750 \\
\hline New York City & 3980 & 20 & 350 & 2302 & 9 & 200 & 16174 & 50 & 800 \\
\hline Philadelphia & 4603 & 20 & 350 & 2110 & 10 & 150 & 17280 & 45 & 700 \\
\hline Phoenix & 5412 & 25 & 350 & 2493 & 9 & 200 & 22265 & 65 & 1000 \\
\hline Washington DC & 4603 & 20 & 350 & 2302 & 9 & 200 & 18024 & 50 & 850 \\
\hline
\end{tabular}


Table B-17. Grocery store prototype characteristics.

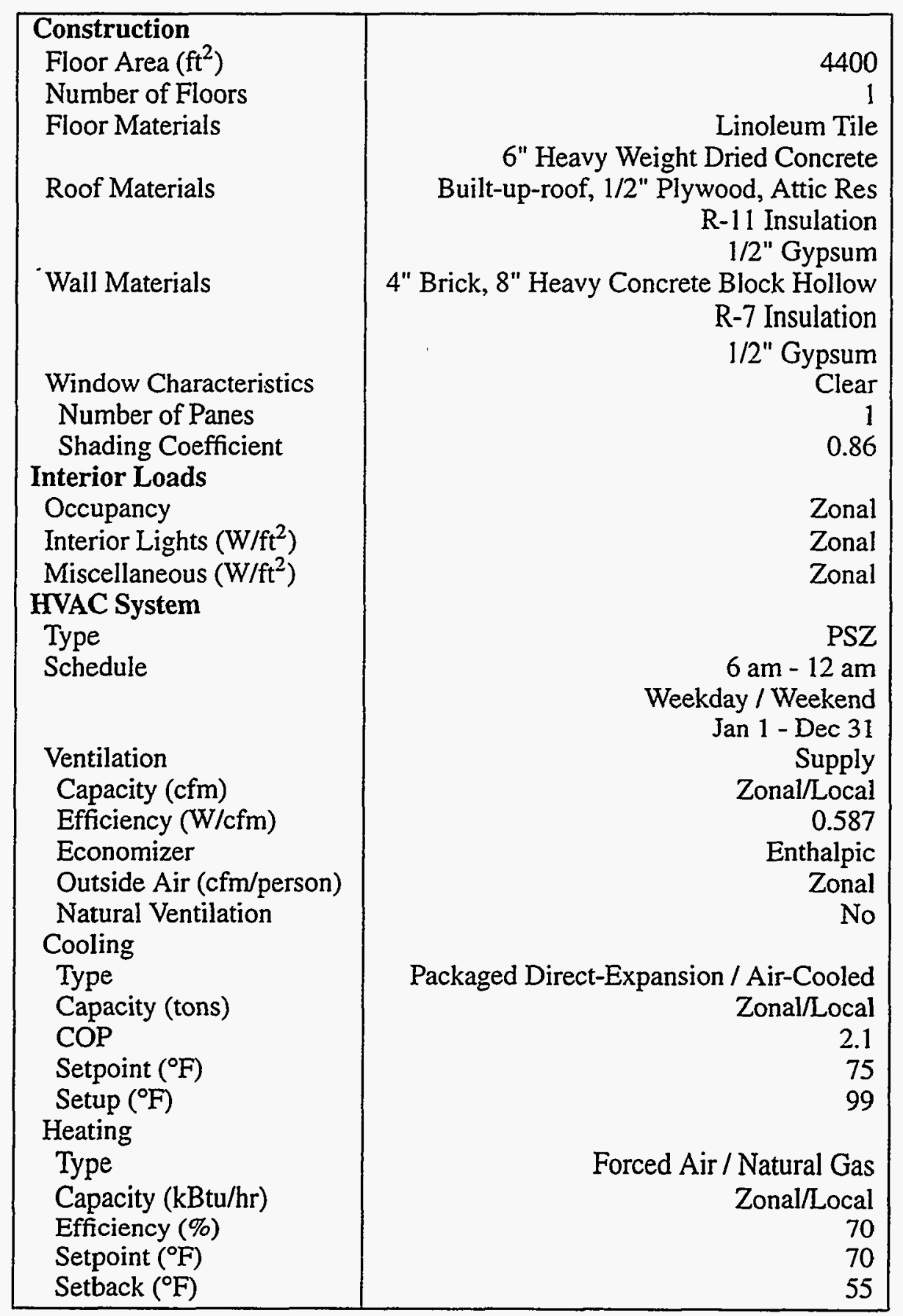

\begin{tabular}{|l|r|r|r|r|r|r|}
\hline & Office & Storage & Bakery & Deli & Sale & Total \\
\hline Floor Area (\% total) & 3 & 20 & 12 & 5 & 60 & 100 \\
Occupancy ( $\mathrm{ft}^{2} / \mathrm{person}$ ) & 130 & 880 & 220 & 220 & 325 & - \\
Outside Air (cfm/person) & 15 & 15 & - & 15 & 15 & - \\
Outside Air (ach) & - & - & 5.6 & - & - & - \\
Interior Lights (W/ $\mathrm{ft}^{2}$ ) & 1.7 & 1.0 & 1.7 & 1.7 & 1.7 & 1.6 \\
Miscellaneous (W/ $\mathrm{ft}^{2}$ ) & 0.5 & 0.4 & 7.5 & 3.8 & 0.4 & 0.6 \\
\hline
\end{tabular}


Table B-18. Grocery store prototype zonal and local HVAC capacities.

\begin{tabular}{|c|c|c|c|c|c|c|c|c|c|c|c|c|c|c|c|}
\hline \multirow{3}{*}{ Location } & \multicolumn{15}{|c|}{ Zone } \\
\hline & \multicolumn{3}{|c|}{ Sales } & \multicolumn{3}{|c|}{ Storage } & \multicolumn{3}{|c|}{ Deli } & \multicolumn{3}{|c|}{ Bakery } & \multicolumn{3}{|c|}{ Office } \\
\hline & $\begin{array}{l}\text { Fan } \\
(\mathrm{cfm})\end{array}$ & $\begin{array}{l}\text { Cooling } \\
\text { (tons) }\end{array}$ & $\begin{array}{l}\text { Heating } \\
\text { (kBtu/hr) }\end{array}$ & $\begin{array}{l}\text { Fan } \\
\text { (cfm) }\end{array}$ & $\begin{array}{l}\text { Cooling } \\
\text { (tons) }\end{array}$ & $\begin{array}{c}\text { Heating } \\
\text { (kBtu/hr) }\end{array}$ & $\begin{array}{l}\text { Fan } \\
(\mathrm{cfm})\end{array}$ & $\begin{array}{l}\text { Cooling } \\
\text { (tons) }\end{array}$ & $\begin{array}{l}\text { Heating } \\
(\mathrm{kBtu} / \mathrm{hr})\end{array}$ & $\begin{array}{l}\text { Fan } \\
(\mathrm{cfm})\end{array}$ & $\begin{array}{l}\text { Cooling } \\
\text { (tons) }\end{array}$ & $\begin{array}{l}\text { Heating } \\
\text { (kBtu/hr) }\end{array}$ & $\begin{array}{l}\text { Fan } \\
\text { (cfm) }\end{array}$ & $\begin{array}{l}\text { Cooling } \\
\text { (tons) }\end{array}$ & $\begin{array}{l}\text { Heating } \\
\text { (kBtu/hr) }\end{array}$ \\
\hline Atlanta & 3457 & 8.0 & 150 & 356 & 1.5 & 25 & 288 & 1.0 & 15 & 1010 & 6.0 & 120 & 106 & 1.0 & 10 \\
\hline Chicago & 3808 & 9.0 & 170 & 537 & 2.0 & 35 & 317 & 1.0 & 15 & 1010 & 6.0 & 140 & 106 & 1.0 & 10 \\
\hline Los Angeles & 3723 & 9.0 & 160 & 303 & 1.5 & 20 & 253 & 1.0 & 15 & 1010 & 5.0 & 75 & 98 & 1.0 & 5 \\
\hline Fort Worth & 4255 & 10.0 & 190 & 462 & 2.0 & 30 & 362 & 1.0 & 20 & 1064 & 6.0 & 100 & 121 & 1.0 & 10 \\
\hline Houston & 3457 & 9.0 & 150 & 266 & 1.5 & 20 & 222 & 1.0 & 10 & 1010 & 7.0 & 100 & 109 & 1.0 & 10 \\
\hline Miami & 3457 & 8.0 & 150 & 443 & 1.5 & 30 & 355 & 1.0 & 20 & 1010 & 6.0 & 90 & 107 & 1.0 & 10 \\
\hline New Orleans & 3191 & 8.0 & 140 & 266 & 1.0 & 20 & 202 & 1.0 & 10 & 1010 & 6.0 & 100 & 106 & 1.0 & 10 \\
\hline New York City & 3791 & 9.0 & 170 & 479 & 2.0 & 30 & 267 & 1.0 & 15 & 1010 & 5.0 & 120 & 99 & 1.0 & 10 \\
\hline Philadelphia & 4057 & 9.0 & 180 & 1152 & 3.5 & 70 & 712 & 2.0 & 35 & 1010 & 5.0 & 110 & 106 & 1.0 & 10 \\
\hline Phoenix & 5052 & 12.5 & 210 & 620 & 2.5 & 40 & 444 & 1.5 & 20 & 1181 & 6.0 & 110 & 146 & 1.0 & 10 \\
\hline Washington DC & 3527 & 9.0 & 160 & 443 & 1.5 & 25 & 273 & 1.0 & 15 & 1010 & 6.0 & 110 & 108 & 1.0 & 10 \\
\hline
\end{tabular}


Table B-19. DOE-2 simulated HVAC base use and savings from light-colored roofing; annual electricity and net energy, peak electricity demand, and annual natural gas estimated per $1000 \mathrm{ft}^{2}$ of flat roof area.

\begin{tabular}{|c|c|c|c|c|c|c|c|c|c|c|c|c|}
\hline \multirow{3}{*}{ Metropolitan Area } & \multicolumn{3}{|c|}{ Old Res w/ Gas Furnace } & \multicolumn{3}{|c|}{ Old Res w/ Heat Pump } & \multicolumn{3}{|c|}{ New Res w/ Gas Furnace } & \multicolumn{3}{|c|}{ New Res w/ Heat Pump } \\
\hline & \multirow{2}{*}{$\begin{array}{l}\text { Base } \\
\text { Case }\end{array}$} & \multicolumn{2}{|c|}{ Savings } & \multirow{2}{*}{$\begin{array}{l}\text { Base } \\
\text { Case }\end{array}$} & \multicolumn{2}{|c|}{ Savings } & \multirow{2}{*}{$\begin{array}{l}\text { Base } \\
\text { Case }\end{array}$} & \multicolumn{2}{|c|}{ Savings } & \multirow{2}{*}{$\begin{array}{l}\text { Base } \\
\text { Case }\end{array}$} & \multicolumn{2}{|c|}{ Savings } \\
\hline & & $\Delta$ & $\%$ & & $\bar{\Delta}$ & $\%$ & & $\bar{\Delta}$ & $\%$ & & $\bar{\Delta}$ & $\%$ \\
\hline \multicolumn{13}{|l|}{ Atlanta } \\
\hline Electricity $\left(\mathrm{kWh} / 1000 \mathrm{ft}^{2}\right)$ & 1994 & 232 & 12 & 5554 & 153 & 3 & 1364 & 125 & 9 & 3350 & 89 & 3 \\
\hline Gas $\left(k B t u / 1000 \mathrm{ft}^{2}\right)$ & 27546 & -697 & -3 & 0 & 0 & 0 & 17351 & -383 & -2 & 0 & 0 & 0 \\
\hline Net Energy $\left(\$ / 1000 \mathrm{ft}^{2}\right)$ & 343 & 14 & 4 & 433 & 12 & 3 & 225 & 8 & 4 & 261 & 6 & 2 \\
\hline Peak $\left(W / 1000 \mathrm{ft}^{2}\right)$ & 2175 & 143 & 7 & 2175 & 143 & 7 & 1455 & 91 & 6 & 1455 & 91 & 6 \\
\hline \multicolumn{13}{|l|}{ Chicago } \\
\hline Electricity $\left(\mathrm{kWh} / 1000 \mathrm{ft}^{2}\right)$ & 1380 & 131 & 9 & 11273 & -19 & 0 & 925 & 72 & 8 & 7001 & -12 & 0 \\
\hline Gas $\left(k B t u / 1000 \mathrm{ft}^{2}\right)$ & 69290 & -1264 & -2 & 0 & 0 & 0 & 46300 & -787 & -2 & 0 & 0 & 0 \\
\hline Net Energy $\left(\$ / 1000 \mathrm{ft}^{2}\right)$ & 536 & 8 & 1 & 1262 & -3 & 0 & 358 & 4 & 1 & 784 & -2 & 0 \\
\hline Peak $\left(W / 1000 \mathrm{ft}^{2}\right)$ & 2305 & 117 & 5 & 2305 & 117 & 5 & 1481 & 52 & 4 & 1481 & 52 & 4 \\
\hline \multicolumn{13}{|l|}{ Los Angeles } \\
\hline Electricity $\left(\mathrm{kWh} / 1000 \mathrm{ft}^{2}\right)$ & 1364 & 238 & 17 & 2588 & 177 & 7 & 846 & 126 & 15 & 1349 & 101 & 7 \\
\hline Gas $\left(k B t u / 1000 \mathrm{ft}^{2}\right)$ & 10721 & -544 & -5 & 0 & 0 & 0 & 5375 & -244 & -5 & 0 & 0 & 0 \\
\hline Net Energy $\left(\$ / 1000 \mathrm{ft}^{2}\right)$ & 200 & 20 & 10 & 254 & 18 & 7 & 116 & 11 & 9 & 132 & 10 & 8 \\
\hline Peak $\left(W / 1000 \mathrm{ft}^{2}\right)$ & 2305 & 247 & 11 & 2305 & 247 & 11 & 1481 & 130 & 9 & 1481 & 130 & 9 \\
\hline \multicolumn{13}{|l|}{ Fort Worth } \\
\hline Electricity $\left(\mathrm{kWh} / 1000 \mathrm{ft}^{2}\right)$ & 3457 & 244 & 7 & 6232 & 185 & 3 & 2364 & 133 & 6 & 3842 & 106 & 3 \\
\hline Gas $\left(k B t u / 1000 f^{2}\right)$ & 21955 & -501 & -2 & 0 & 0 & 0 & 13294 & -277 & -2 & 0 & 0 & 0 \\
\hline Net Energy $\left(\$ / 1000 \mathrm{ft}^{2}\right)$ & 395 & 16 & 4 & 480 & 14 & 3 & 260 & 8 & 3 & 296 & 8 & 3 \\
\hline Peak $\left(W / 1000 \mathrm{ft}^{2}\right)$ & 3221 & 175 & 5 & 3221 & 175 & 5 & 2097 & 97 & 5 & 2097 & 97 & 5 \\
\hline \multicolumn{13}{|l|}{ Houston } \\
\hline Electricity $\left(\mathrm{kWh} / 1000 \mathrm{ft}^{2}\right)$ & 2986 & 279 & 9 & 4505 & 238 & 5 & 1990 & 151 & 8 & 2759 & 129 & 5 \\
\hline Gas $\left(k B t u / 1000 \mathrm{ft}^{2}\right)$ & 12542 & -352 & -3 & 0 & 0 & 0 & 7338 & -204 & -3 & 0 & 0 & 0 \\
\hline Net Energy $\left(\$ / 1000 \mathrm{ft}^{2}\right)$ & 352 & 24 & 7 & 419 & 22 & 5 & 229 & 13 & 6 & 256 & 12 & 5 \\
\hline $\operatorname{Peak}\left(W / 1000 \mathrm{ft}^{2}\right)$ & 2981 & 130 & 4 & 2981 & 130 & 4 & 1981 & 110 & 6 & 1981 & 110 & 6 \\
\hline \multicolumn{13}{|l|}{ Miami } \\
\hline Electricity $\left(\mathrm{kWh} / 1000 \mathrm{ft}^{2}\right)$ & 5150 & 376 & 7 & 5277 & 374 & 7 & 3689 & 205 & 6 & 3734 & 205 & 5 \\
\hline Gas $\left(k B t u / 1000 \mathrm{ft}^{2}\right)$ & 1086 & -20 & -2 & 0 & 0 & 0 & 457 & -1 & 0 & 0 & 0 & 0 \\
\hline Net Energy $\left(\$ / 1000 \mathrm{ft}^{2}\right)$ & 428 & 30 & 7 & 427 & 30 & 7 & 303 & 16 & 5 & 303 & 17 & 6 \\
\hline Peak $\left(W / 1000 \mathrm{ft}^{2}\right)$ & 2409 & 208 & 9 & 2409 & 208 & 9 & 1545 & 84 & 5 & 1545 & 84 & 5 \\
\hline
\end{tabular}


Table B-19(Cont). DOE-2 simulated HVAC base use and savings from light-colored roofing; annual electricity and net energy, peak electricity demand, and annual natural gas estimated per $1000 \mathrm{ft}^{2}$ of flat roof area.

\begin{tabular}{|c|c|c|c|c|c|c|c|c|c|c|c|c|}
\hline \multirow{3}{*}{ Metropolitan Area } & \multicolumn{3}{|c|}{ Old Res w/ Gas Furnace } & \multicolumn{3}{|c|}{ Old Res w/ Heat Pump } & \multicolumn{3}{|c|}{ New Res w/ Gas Furnace } & \multicolumn{3}{|c|}{ New Res w/ Heat Pump } \\
\hline & \multirow{2}{*}{$\begin{array}{l}\text { Base } \\
\text { Case }\end{array}$} & \multicolumn{2}{|c|}{ Savings } & \multirow{2}{*}{$\begin{array}{l}\text { Base } \\
\text { Case }\end{array}$} & \multicolumn{2}{|c|}{ Savings } & \multirow{2}{*}{$\begin{array}{l}\text { Base } \\
\text { Case }\end{array}$} & \multicolumn{2}{|c|}{ Savings } & \multirow{2}{*}{$\begin{array}{l}\text { Base } \\
\text { Case }\end{array}$} & \multicolumn{2}{|c|}{ Savings } \\
\hline & & $\Delta$ & $\%$ & & $\Delta$ & $\%$ & & $\bar{\Delta}$ & $\%$ & & $\bar{\Delta}$ & $\%$ \\
\hline New Orleans & & & & & & & & & & & & \\
\hline Electricity $\left(\mathrm{kWh} / 1000 \mathrm{ft}^{2}\right)$ & 2584 & 283 & 11 & 3813 & 241 & 6 & 1766 & $17 !$ & 10 & 2386 & 149 & 6 \\
\hline Gas $\left(k B t u / 1000 \mathrm{ft}^{2}\right)$ & 10877 & -384 & -4 & 0 & 0 & 0 & 6101 & -226 & -4 & 0 & 0 & 0 \\
\hline Net Energy $\left(\$ / 1000 \mathrm{ft}^{2}\right)$ & 271 & 20 & 7 & 301 & 19 & 6 & 177 & 12 & 7 & 188 & 12 & 6 \\
\hline Peak $\left(W / 1000 \mathrm{ft}^{2}\right)$ & 2130 & 71 & 3 & 2130 & 71 & 3 & 1494 & 84 & 6 & 1494 & 84 & 6 \\
\hline \multicolumn{13}{|l|}{ New York City } \\
\hline Electricity $\left(\mathrm{kWh} / 1000 \mathrm{ft}^{2}\right)$ & 1229 & 106 & 9 & 8729 & 1 & 0 & 836 & 57 & 7 & 5315 & 4 & 0 \\
\hline Gas $\left(k B t u / 1000 \mathrm{ft}^{2}\right)$ & 58363 & -967 & -2 & 0 & 0 & 0 & 39334 & -587 & -1 & 0 & 0 & 0 \\
\hline Net Energy $\left(\$ / 1000 \mathrm{ft}^{2}\right)$ & 669 & 9 & 1 & 1397 & 0 & 0 & 453 & 5 & 1 & 851 & 1 & 0 \\
\hline Peak (W/1000ft $\left.{ }^{2}\right)$ & 2292 & 169 & 7 & 2292 & 169 & 7 & 1448 & 84 & 6 & 1448 & 84 & 6 \\
\hline \multicolumn{13}{|l|}{ Philadelphia } \\
\hline Electricity $\left(\mathrm{kWh} / 1000 \mathrm{ft}^{2}\right)$ & 736 & 103 & 14 & 10923 & -96 & -1 & 431 & 42 & 10 & 7353 & -78 & -1 \\
\hline Gas $\left(\mathrm{kBtu} / 1000 \mathrm{ft}^{2}\right)$ & 78118 & -1823 & -2 & 0 & 0 & 0 & 59284 & -1302 & -2 & 0 & 0 & 0 \\
\hline Net Energy $\left(\$ / 1000 \mathrm{ft}^{2}\right)$ & 625 & 1 & 0 & 1398 & -12 & -1 & 458 & -3 & -1 & 941 & -10 & -1 \\
\hline Peak $\left(W / 1000 \mathrm{ft}^{2}\right)$ & 1545 & 201 & 13 & 1545 & 201 & 13 & 922 & 91 & 10 & 922 & 91 & 10 \\
\hline \multicolumn{13}{|l|}{ Phoenix } \\
\hline Electricity $\left(\mathrm{kWh} / 1000 \mathrm{ft}^{2}\right)$ & 5495 & 484 & 9 & 6643 & 459 & 7 & 3590 & 256 & 7 & 4102 & 247 & 6 \\
\hline Gas $\left(k B t u / 1000 \mathrm{ft}^{2}\right)$ & 9388 & -211 & -2 & 0 & 0 & 0 & 4816 & -90 & -2 & 0 & 0 & 0 \\
\hline Net Energy $\left(\$ / 1000 \mathrm{ft}^{2}\right)$ & 656 & 51 & 8 & 711 & 49 & 7 & 419 & 27 & 6 & 439 & 27 & 6 \\
\hline Peak $\left(W / 1000 \mathrm{ft}^{2}\right)$ & 4123 & 162 & 4 & 4123 & 162 & 4 & 2656 & 97 & 4 & 2656 & 97 & 4 \\
\hline \multicolumn{13}{|l|}{ Washington DC } \\
\hline Electricity $\left(\mathrm{kWh} / 1000 \mathrm{ft}^{2}\right)$ & 1794 & 186 & 10 & 7283 & 82 & 1 & 1210 & 101 & 8 & 4382 & 45 & 1 \\
\hline Gas $\left(k B t u / 1000 \mathrm{ft}^{2}\right)$ & 42818 & -966 & -2 & 0 & 0 & 0 & 28171 & -605 & -2 & 0 & 0 & 0 \\
\hline Net Energy $\left(\$ / 1000 \mathrm{ft}^{2}\right)$ & 484 & 5 & 1 & 525 & 6 & 1 & 321 & 2 & 1 & 316 & 3 & 1 \\
\hline Peak $\left(W / 1000 \mathrm{ft}^{2}\right)$ & 2584 & 162 & 6 & 2584 & 162 & 6 & 1649 & 84 & 5 & 1649 & 84 & 5 \\
\hline
\end{tabular}


Table B-19(Cont). DOE-2 simulated HVAC base use and savings from light-colored roofing; annual electricity and net energy, peak electricity demand, and annual natural gas estimated per $1000 \mathrm{ft}^{2}$ of flat roof area.

\begin{tabular}{|c|c|c|c|c|c|c|c|c|c|c|c|c|}
\hline \multirow{3}{*}{ Metropolitan Area } & \multicolumn{3}{|c|}{ Old Office $w /$ Gas Furnace } & \multicolumn{3}{|c|}{ Old Office w/ Heat Pump } & \multicolumn{3}{|c|}{ New Office w/ Gas Furnace } & \multicolumn{3}{|c|}{ New Office w/ Heat Pump } \\
\hline & \multirow{2}{*}{$\begin{array}{l}\text { Base } \\
\text { Case }\end{array}$} & \multicolumn{2}{|c|}{ Savings } & \multirow{2}{*}{$\begin{array}{l}\text { Base } \\
\text { Case }\end{array}$} & \multicolumn{2}{|c|}{ Savings } & \multirow{2}{*}{$\begin{array}{l}\text { Base } \\
\text { Case }\end{array}$} & \multicolumn{2}{|c|}{ Savings } & \multirow{2}{*}{$\begin{array}{l}\text { Base } \\
\text { Case }\end{array}$} & \multicolumn{2}{|c|}{ Savings } \\
\hline & & $\Delta$ & $\%$ & & $\bar{\Delta}$ & $\%$ & & $\bar{\Delta}$ & $\%$ & & $\Delta$ & $\%$ \\
\hline$\overline{\text { Atlanta }}$ & & & & & & & & & & & & \\
\hline Electricity $\left(\mathrm{kWh} / 1000 \mathrm{ft}^{2}\right)$ & 4521 & 293 & 6 & 5866 & 203 & 3 & 3402 & 168 & 5 & 4120 & 120 & 3 \\
\hline Natural Gas $\left(\mathrm{kBtu} / 1000 \mathrm{ft}^{2}\right)$ & 9571 & -776 & -8 & 0 & 0 & 0 & 5531 & -388 & -7 & 0 & 0 & 0 \\
\hline Net Energy $\left(\$ / 1000 \mathrm{ft}^{2}\right)$ & 390 & 17 & 4 & 434 & 15 & 3 & 284 & 10 & 4 & 305 & 9 & 3 \\
\hline Peak $\left(W / 1000 \mathrm{ft}^{2}\right)$ & 3922 & 247 & 6 & 3922 & 247 & 6 & 2822 & 118 & 4 & 2822 & 118 & 4 \\
\hline \multicolumn{13}{|l|}{ Chicago } \\
\hline Electricity $\left(\mathrm{kWh} / 1000 \mathrm{ft}^{2}\right)$ & 3396 & 191 & 6 & 8347 & 12 & 0 & 2679 & 108 & 4 & 5782 & 6 & 0 \\
\hline Natural Gas $\left(\mathrm{kBtu} / 1000 \mathrm{ft}^{2}\right)$ & 32041 & -1367 & -4 & 0 & 0 & 0 & 21388 & -816 & -4 & 0 & 0 & 0 \\
\hline Net Energy $\left(\$ / 1000 \mathrm{ft}^{2}\right)$ & 449 & 9 & 2 & 701 & 1 & 0 & 334 & 5 & 1 & 486 & 0 & 0 \\
\hline Peak $\left(W / 1000 \mathrm{ft}^{2}\right)$ & 4047 & 198 & 5 & 4047 & 198 & 5 & 3004 & 129 & 4 & 3004 & 129 & 4 \\
\hline \multicolumn{13}{|l|}{ Los Angeles } \\
\hline Electricity $\left(\mathrm{kWh} / 1000 \mathrm{ft}^{2}\right)$ & 4174 & 377 & 9 & 4293 & 341 & 8 & 3271 & 221 & 7 & 3301 & 215 & 7 \\
\hline Natural Gas $\left(\mathrm{kBtu} / 1000 \mathrm{ft}^{2}\right)$ & 878 & -306 & -35 & 0 & 0 & 0 & 224 & -82 & -37 & 0 & 0 & 0 \\
\hline Net Energy $\left(\$ / 1000 \mathrm{ft}^{2}\right)$ & 377 & 32 & 8 & 382 & 30 & 8 & 292 & 19 & 7 & 294 & 19 & 6 \\
\hline Peak $\left(W / 1000 \mathrm{ft}^{2}\right)$ & 3914 & 292 & 7 & 3914 & 292 & 7 & 2886 & 173 & 6 & 2886 & 173 & 6 \\
\hline \multicolumn{13}{|l|}{ Fort Worth } \\
\hline Electricity $\left(\mathrm{kWh} / 1000 \mathrm{ft}^{2}\right)$ & 6105 & 305 & 5 & 7038 & 221 & 3 & 4670 & 161 & 3 & 5119 & 126 & 2 \\
\hline Natural Gas $\left(k B t u / 1000 \mathrm{ft}^{2}\right)$ & 6735 & -571 & -8 & 0 & 0 & 0 & 3449 & -306 & -9 & 0 & 0 & 0 \\
\hline Net Energy $\left(\$ / 1000 \mathrm{ft}^{2}\right)$ & 420 & 17 & 4 & 450 & 14 & 3 & 314 & 9 & 3 & 328 & 8 & 2 \\
\hline Peak $\left(W / 1000 \mathrm{ft}^{2}\right)$ & 5167 & 155 & 3 & 5167 & 155 & 3 & 3792 & 100 & 3 & 3792 & 100 & 3 \\
\hline \multicolumn{13}{|l|}{ Houston } \\
\hline Electricity $\left(\mathrm{kWh} / 1000 \mathrm{ft}^{2}\right)$ & 6087 & 335 & 6 & 6464 & 299 & 5 & 4604 & 185 & 4 & 4772 & 167 & 3 \\
\hline Natural Gas $\left(\mathrm{kBtu} / 1000 \mathrm{ft}^{2}\right)$ & 2837 & -327 & -12 & 0 & 0 & 0 & 1367 & -143 & -10 & 0 & 0 & 0 \\
\hline Net Energy $\left(\$ / 1000 \mathrm{ft}^{2}\right)$ & 475 & 24 & 5 & 491 & 23 & 5 & 356 & 13 & 4 & 363 & 13 & 4 \\
\hline Peak $\left(W / 1000 \mathrm{ft}^{2}\right)$ & 4620 & 243 & 5 & 4620 & 243 & 5 & 3298 & 141 & 4 & 3298 & 141 & 4 \\
\hline \multicolumn{13}{|l|}{ Miami } \\
\hline Electricity $\left(\mathrm{kWh} / 1000 \mathrm{ft}^{2}\right)$ & 8664 & 424 & 5 & 8670 & 418 & 5 & 6536 & 239 & 4 & 6536 & 233 & 4 \\
\hline Natural Gas $\left(\mathrm{kBtu} / 1000 \mathrm{ft}^{2}\right)$ & 61 & 0 & 0 & 0 & 0 & 0 & 0 & 0 & 0 & 0 & 0 & 0 \\
\hline Net Energy $\left(\$ / 1000 \mathrm{ft}^{2}\right)$ & 590 & 29 & 5 & 590 & 28 & 5 & 444 & 16 & 4 & 444 & 16 & 4 \\
\hline Peak $\left(W / 1000 \mathrm{ft}^{2}\right)$ & 4482 & 153 & 3 & 4482 & 153 & 3 & 3208 & 57 & 2 & 3208 & 57 & 2 \\
\hline
\end{tabular}


Table B-19(Cont). DOE-2 simulated HVAC base use and savings from light-colored roofing; annual electricity and net energy, peak electricity demand, and annual natural gas estimated per $1000 \mathrm{ft}^{2}$ of flat roof area.

\begin{tabular}{|c|c|c|c|c|c|c|c|c|c|c|c|c|}
\hline \multirow{3}{*}{ Metropolitan Area } & \multicolumn{3}{|c|}{ Old Office w/ Gas Furnace } & \multicolumn{3}{|c|}{ Old Office w/ Heat Pump } & \multicolumn{3}{|c|}{ New Office w/ Gas Furnace } & \multicolumn{3}{|c|}{ New Office w/ Heat Pump } \\
\hline & \multirow{2}{*}{$\begin{array}{l}\text { Base } \\
\text { Case }\end{array}$} & \multicolumn{2}{|c|}{ Savings } & \multirow{2}{*}{$\begin{array}{l}\text { Base } \\
\text { Case }\end{array}$} & \multicolumn{2}{|c|}{ Savings } & \multirow{2}{*}{$\begin{array}{l}\text { Base } \\
\text { Case }\end{array}$} & \multicolumn{2}{|c|}{ Savings } & \multirow{2}{*}{$\begin{array}{l}\text { Base } \\
\text { Case }\end{array}$} & \multicolumn{2}{|c|}{ Savings } \\
\hline & & $\Delta$ & $\%$ & & $\Delta$ & $\%$ & & $\Delta$ & $\%$ & & $\Delta$ & $\%$ \\
\hline New Orleans & & & & & & & & & & & & \\
\hline Electricity $\left(\mathrm{kWh} / 1000 \mathrm{ft}^{2}\right)$ & 5902 & 383 & 6 & 6261 & 341 & 5 & 4341 & 209 & 5 & 4503 & 191 & 4 \\
\hline Natural Gas $\left(\mathrm{kBtu} / 1000 \mathrm{ft}^{2}\right)$ & 2673 & -367 & -14 & 0 & 0 & 0 & 1347 & -163 & -12 & 0 & 0 & 0 \\
\hline Net Energy $\left(\$ / 1000 \mathrm{ft}^{2}\right)$ & 510 & 30 & 6 & 526 & 29 & 6 & 372 & 17 & 5 & 378 & 16 & 4 \\
\hline Peak $\left(W / 1000 \mathrm{ft}^{2}\right)$ & 4508 & 314 & 7 & 4508 & 314 & 7 & 3106 & 143 & 5 & 3106 & 143 & 5 \\
\hline New York City & & & & & & & & Jדו & & (1) & 145 & J \\
\hline Electricity $\left(\mathrm{kWh} / 1000 \mathrm{ft}^{2}\right)$ & 3361 & 168 & 5 & 7062 & 54 & 1 & 2553 & 96 & 4 & 4820 & 36 & 1 \\
\hline Natural Gas $\left(\mathrm{kBtu} / 1000 \mathrm{ft}^{2}\right)$ & 26673 & -939 & -4 & 0 & 0 & 0 & 18061 & -551 & -3 & 0 & 0 & 0 \\
\hline Net Energy $\left(\$ / 1000 \mathrm{ft}^{2}\right)$ & 589 & 15 & 3 & 890 & 7 & 1 & 434 & 9 & 2 & 607 & 4 & 1 \\
\hline Peak $\left(W / 1000 \mathrm{ft}^{2}\right)$ & 4098 & 163 & 4 & 4098 & 163 & 4 & 2859 & 63 & 2 & 2859 & 63 & 2 \\
\hline Philadelphia & & & & & & & & & & & & \\
\hline Electricity $\left(\mathrm{kWh} / 1000 \mathrm{ft}^{2}\right)$ & 2792 & 221 & 8 & 7845 & 6 & 0 & 2033 & 120 & 6 & 5549 & 0 & 0 \\
\hline Natural Gas $\left(\mathrm{kBtu} / 1000 \mathrm{ft}^{2}\right)$ & 34714 & -1796 & -5 & 0 & 0 & 0 & 26347 & -1163 & -4 & 0 & 0 & 0 \\
\hline Net Energy $\left(\$ / 1000 \mathrm{ft}^{2}\right)$ & 538 & 15 & 3 & 926 & 1 & 0 & 398 & 7 & 2 & 655 & 0 & 0 \\
\hline Peak $\left(W / 1000 \mathrm{ft}^{2}\right)$ & 3335 & 247 & 7 & 3335 & 247 & 7 & 2306 & 131 & 6 & 2306 & 131 & 6 \\
\hline Phoenix & & & & & & & & & & & & \\
\hline Electricity $\left(\mathrm{kWh} / 1000 \mathrm{ft}^{2}\right)$ & 8030 & 562 & 7 & 8192 & 538 & 7 & 5848 & 305 & 5 & 5890 & 293 & 5 \\
\hline Natural Gas $\left(\mathrm{kBtu} / 1000 \mathrm{ft}^{2}\right)$ & 1000 & -265 & -26 & 0 & 0 & 0 & 286 & -82 & -29 & 0 & 0 & 0 \\
\hline Net Energy $\left(\$ / 1000 \mathrm{ft}^{2}\right)$ & 744 & 50 & 7 & 754 & 50 & 7 & 539 & 28 & 5 & 542 & 27 & 5 \\
\hline Peak $\left(W / 1000 \mathrm{ft}^{2}\right)$ & 5857 & 196 & 3 & 5857 & 196 & 3 & 4065 & 96 & 2 & 4065 & 96 & 2 \\
\hline Washington DC & & & & & & & & & & & & \\
\hline Electricity $\left(\mathrm{kWh} / 1000 \mathrm{ft}^{2}\right)$ & 4132 & 251 & 6 & 6691 & 119 & 2 & 3205 & 138 & 4 & 4634 & 66 & 1 \\
\hline Natural Gas $\left(\mathrm{kBtu} / 1000 \mathrm{ft}^{2}\right)$ & 18102 & -1082 & -6 & 0 & 0 & 0 & 10980 & -633 & -6 & 0 & 0 & 0 \\
\hline Net Energy $\left(\$ / 1000 \mathrm{ft}^{2}\right)$ & 398 & 12 & 3 & 475 & 9 & 2 & 291 & 6 & 2 & 329 & 5 & 2 \\
\hline Peak $\left(W / 1000 \mathrm{ft}^{2}\right)$ & 4106 & 233 & 6 & 4106 & 233 & 6 & 2953 & 124 & 4 & 2953 & 124 & 4 \\
\hline
\end{tabular}


Table B-19(Cont). DOE-2 simulated HVAC base use and savings from light-colored roofing; annual electricity and net energy, peak electricity demand, and annual natural gas estimated per $1000 \mathrm{ft}^{2}$ of flat roof area.

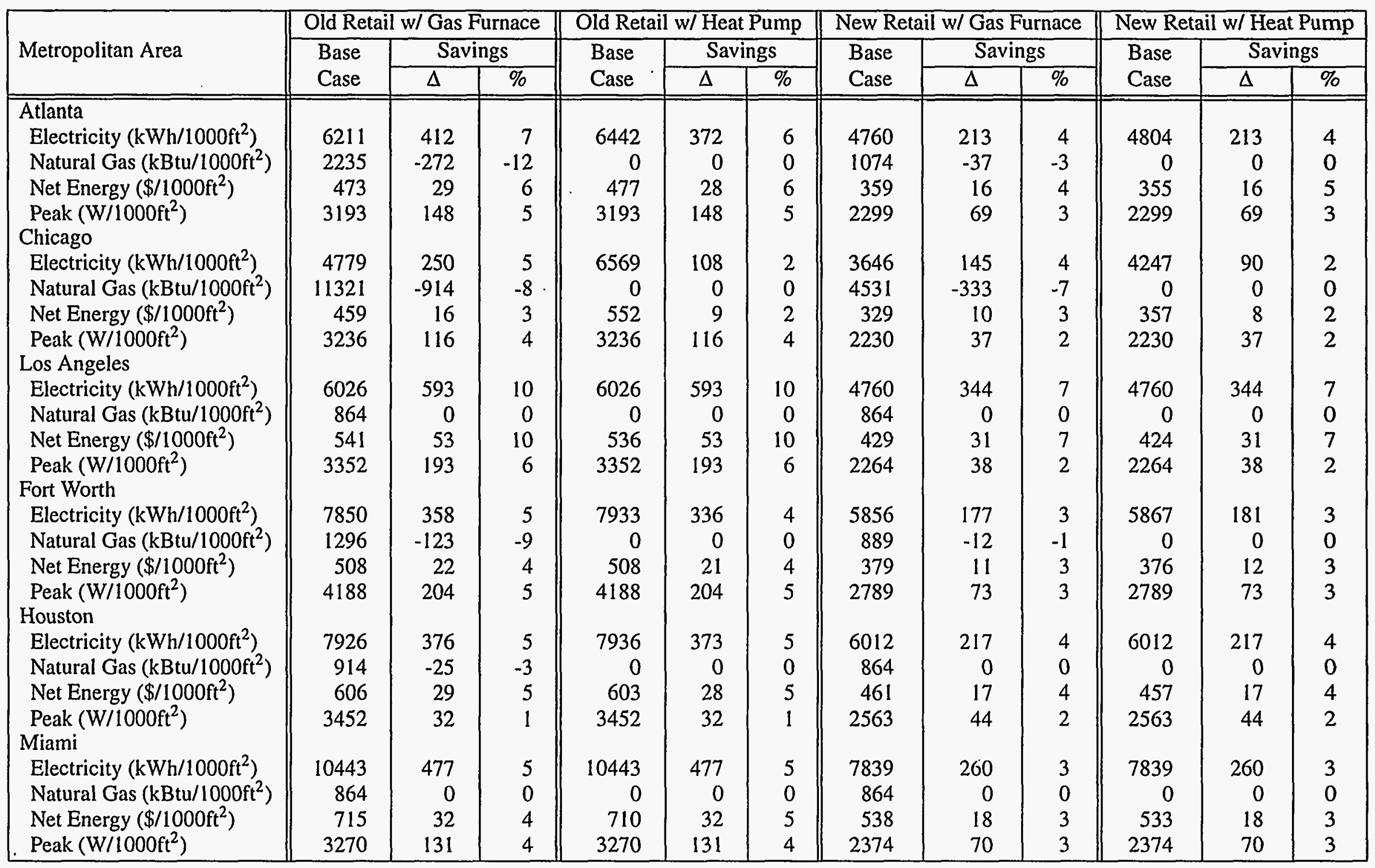


Table B-19(Cont). DOE-2 simulated HVAC base use and savings from light-colored roofing; annual electricity and net energy, peak electricity demand, and annual natural gas estimated per $1000 \mathrm{ft}^{2}$ of flat roof area.

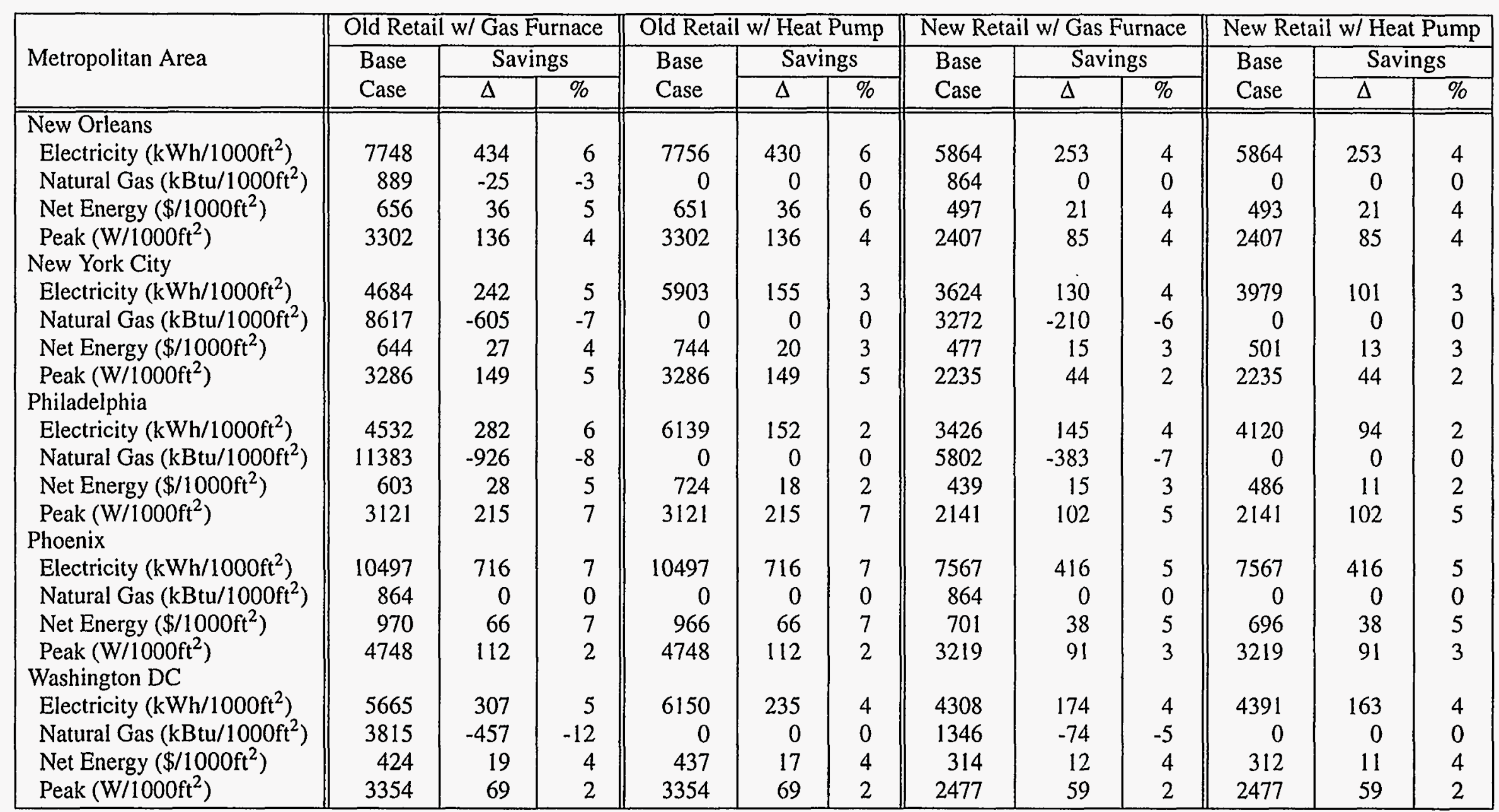


Table B-19(Cont). DOE-2 simulated HVAC base use and savings from light-colored roofing; annual electricity and net energy, peak electricity demand, and annual natural gas estimated per $1000 \mathrm{ft}^{2}$ of flat roof area.

\begin{tabular}{|c|c|c|c|c|c|c|c|c|c|c|c|c|}
\hline \multirow{3}{*}{ Metropolitan Area } & \multicolumn{3}{|c|}{ Primary School } & \multicolumn{3}{|c|}{ Secondary School } & \multicolumn{3}{|c|}{ Hospital } & \multicolumn{3}{|c|}{ Nursing Home } \\
\hline & \multirow{2}{*}{$\begin{array}{l}\text { Base } \\
\text { Case }\end{array}$} & \multicolumn{2}{|c|}{ Savings } & \multirow{2}{*}{$\begin{array}{l}\text { Base } \\
\text { Case }\end{array}$} & \multicolumn{2}{|c|}{ Savings } & \multirow{2}{*}{$\begin{array}{l}\text { Base } \\
\text { Case }\end{array}$} & \multicolumn{2}{|c|}{ Savings } & \multirow{2}{*}{$\begin{array}{l}\text { Base } \\
\text { Case }\end{array}$} & \multicolumn{2}{|c|}{ Savings } \\
\hline & & $\bar{\Delta}$ & $\%$ & & $\bar{\Delta}$ & $\%$ & & $\bar{\Delta}$ & $\%$ & & $\bar{\Delta}$ & $\%$ \\
\hline Atlanta & & & & & & & & & & & & \\
\hline Electricity $\left(\mathrm{kWh} / 1000 \mathrm{ft}^{2}\right)$ & 3231 & 151 & 5 & 3547 & 240 & 7 & 16240 & 938 & 6 & 7388 & 495 & 7 \\
\hline Natural Gas $\left(\mathrm{kBtu} / 1000 \mathrm{ft}^{2}\right)$ & 12246 & -674 & -6 & 19318 & -1314 & -7 & 13603 & -5131 & -38 & 7020 & -602 & -9 \\
\hline Net Energy $\left(\$ / 1000 \mathrm{ft}^{2}\right)$ & 310 & 7 & 2 & 375 & 10 & 3 & 1281 & 42 & 3 & 587 & 33 & 6 \\
\hline Peak $\left(W / 1000 \mathrm{ft}^{2}\right)$ & 5131 & 100 & 2 & 4064 & 217 & 5 & 3938 & 427 & 11 & 3277 & 259 & 8 \\
\hline Chicago & & & & & & & & & & & & \\
\hline Electricity $\left(\mathrm{kWh} / 1000 \mathrm{ft}^{2}\right)$ & 2269 & 76 & 3 & 2748 & 145 & 5 & 13789 & 455 & 3 & 5394 & 557 & 10 \\
\hline Natural Gas $\left(\mathrm{kBtu} / 1000 \mathrm{ft}^{2}\right)$ & 34386 & -1037 & -3 & 46462 & -1608 & -3 & 49872 & -8701 & -17 & 29607 & -1670 & -6 \\
\hline Net Energy $\left(\$ / 1000 \mathrm{ft}^{2}\right)$ & 366 & 1 & 0 & 468 & 4 & 1 & 1413 & -7 & 0 & 604 & 38 & 6 \\
\hline Peak $\left(W / 1000 \mathrm{ft}^{2}\right)$ & 5290 & 42 & 1 & 4212 & 133 & 3 & 3920 & 231 & 6 & 3003 & 246 & 8 \\
\hline Los Angeles & & & & & & & & & & & & \\
\hline Electricity $\left(\mathrm{kWh} / 1000 \mathrm{ft}^{2}\right)$ & 3438 & 257 & 7 & 3173 & 299 & 9 & 16106 & 1211 & 8 & 6259 & 677 & 11 \\
\hline Natural Gas $\left(\mathrm{kBtu} / 1000 \mathrm{ft}^{2}\right)$ & 2649 & -417 & -16 & 6688 & -1402 & -21 & 404 & -2632 & -651 & 1495 & -224 & -15 \\
\hline Net Energy $\left(\$ / 1000 \mathrm{ft}^{2}\right)$ & 322 & 20 & 6 & 322 & 18 & 6 & 1436 & 91 & 6 & 566 & 59 & 10 \\
\hline Peak $\left(W / 1000 \mathrm{ft}^{2}\right)$ & 5259 & 133 & 3 & 3769 & 200 & 5 & 3886 & 427 & 11 & 3286 & 283 & 9 \\
\hline Fort Worth & & & & & & & & & & & & \\
\hline Electricity $\left(\mathrm{kWh} / 1000 \mathrm{ft}^{2}\right)$ & 4164 & 135 & 3 & 4506 & 168 & 4 & 18575 & 1057 & 6 & 9539 & 750 & 8 \\
\hline Natural Gas $\left(\mathrm{kBtu} / 1000 \mathrm{ft}^{2}\right)$ & 8140 & -457 & -6 & 14700 & -962 & -7 & 7709 & -4361 & -57 & 4512 & -391 & -9 \\
\hline Net Energy $\left(\$ / 1000 \mathrm{ft}^{2}\right)$ & 302 & 7 & 2 & 353 & 7 & 2 & 1223 & 49 & 4 & 630 & 46 & 7 \\
\hline Peak $\left(W / 1000 \mathrm{ft}^{2}\right)$ & 6339 & 39 & 1 & 4997 & 47 & 1 & 4363 & 462 & 11 & 4072 & 277 & 7 \\
\hline Houst & & & & & & & & & & & & \\
\hline Electricity $\left(\mathrm{kWh} / 1000 \mathrm{ft}^{2}\right)$ & 4886 & 186 & 4 & 5201 & 290 & 6 & 18460 & 1057 & 6 & 8795 & 756 & 9 \\
\hline Natural Gas $\left(\mathrm{kBtu} / 1000 \mathrm{ft}^{2}\right)$ & 4246 & -277 & -7 & 7989 & -693 & -9 & 2593 & -2275 & -88 & 2563 & -216 & -8 \\
\hline Net Energy $\left(\$ / 1000 \mathrm{ft}^{2}\right)$ & 390 & 13 & 3 & 430 & 19 & 4 & 1414 & 70 & 5 & 680 & 57 & 8 \\
\hline Peak $\left(W / 1000 \mathrm{ft}^{2}\right)$ & 5845 & 50 & 1 & 4796 & 175 & 4 & 4158 & 399 & 10 & 3528 & 324 & 9 \\
\hline Miami & & & & & & & & & & & & \\
\hline Electricity $\left(\mathrm{kWh} / 1000 \mathrm{ft}^{2}\right)$ & 7451 & 239 & 3 & 7691 & 317 & 4 & 21092 & 1316 & 6 & 13827 & 878 & 6 \\
\hline Natural Gas $\left(\mathrm{kBtu} / 1000 \mathrm{ft}^{2}\right)$ & 669 & -6 & -1 & 1158 & -161 & -14 & 38 & -273 & -718 & 573 & -5 & -1 \\
\hline Net Energy $\left(\$ / 1000 \mathrm{ft}^{2}\right)$ & 511 & 16 & 3 & 530 & 21 & 4 & 1435 & 91 & 6 & 944 & 60 & 6 \\
\hline Peak $\left(W / 1000 \mathrm{ft}^{2}\right)$ & 5778 & 100 & 2 & 4713 & 79 & 2 & 3995 & 336 & 8 & 3552 & 258 & 7 \\
\hline
\end{tabular}


Table B-19(Cont). DOE-2 simulated HVAC base use and savings from light-colored roofing; annual electricity and net energy, peak electricity demand, and annual natural gas estimated per $1000 \mathrm{ft}^{2}$ of flat roof area.

\begin{tabular}{|c|c|c|c|c|c|c|c|c|c|c|c|c|}
\hline \multirow{3}{*}{ Metropolitan Area } & \multicolumn{3}{|c|}{ Primary School } & \multicolumn{3}{|c|}{ Secondary School } & \multicolumn{3}{|c|}{ Hospital } & \multicolumn{3}{|c|}{ Nursing Home } \\
\hline & \multirow{2}{*}{$\begin{array}{l}\text { Base } \\
\text { Case }\end{array}$} & \multicolumn{2}{|c|}{ Savings } & \multirow{2}{*}{$\begin{array}{l}\text { Base } \\
\text { Case }\end{array}$} & \multicolumn{2}{|c|}{ Savings } & \multirow{2}{*}{$\begin{array}{l}\text { Base } \\
\text { Case }\end{array}$} & \multicolumn{2}{|c|}{ Savings } & \multirow{2}{*}{$\begin{array}{l}\text { Base } \\
\text { Case }\end{array}$} & \multicolumn{2}{|c|}{ Savings } \\
\hline & & $\Delta$ & $\%$ & & $\Delta$ & $\%$ & & $\Delta$ & $\%$ & & $\Delta$ & $\%$ \\
\hline \multicolumn{13}{|l|}{ New Orleans } \\
\hline Electricity $\left(\mathrm{kWh} / 1000 \mathrm{ft}^{2}\right)$ & 4747 & 223 & 5 & 4999 & 247 & 5 & 18238 & 1190 & 7 & 8563 & 805 & 9 \\
\hline Natural Gas $\left(\mathrm{kBtu} / 1000 \mathrm{ft}^{2}\right)$ & 4374 & -357 & -8 & 8492 & -830 & -10 & 2115 & -2464 & -117 & 2378 & -255 & -11 \\
\hline Net Energy $\left(\$ / 1000 \mathrm{ft}^{2}\right)$ & 422 & 17 & 4 & 465 & 16 & 3 & 1543 & 84 & 5 & 732 & 66 & 9 \\
\hline Peak (W/1000ft $\left.{ }^{2}\right)$ & 6079 & 127 & 2 & 4528 & 102 & 2 & 3933 & 294 & 7 & 3289 & 306 & 9 \\
\hline \multicolumn{13}{|l|}{ New York City } \\
\hline Electricity $\left(\mathrm{kWh} / 1000 \mathrm{ft}^{2}\right)$ & 2120 & 80 & 4 & 2616 & 126 & 5 & 13787 & 525 & 4 & 5286 & 434 & 8 \\
\hline Natural Gas (kBtu/1000 $\left.\mathrm{ft}^{2}\right)$ & 27526 & -766 & -3 & 38728 & -1176 & -3 & 37274 & -5439 & -15 & 20617 & -1068 & -5 \\
\hline Net Energy $\left(\$ / 1000 \mathrm{ft}^{2}\right)$ & 438 & 5 & 1 & 570 & 9 & 2 & 1968 & 35 & 2 & 794 & 48 & 6 \\
\hline Peak $\left(W / 1000 \mathrm{ft}^{2}\right)$ & 4461 & 65 & 1 & 3645 & 121 & 3 & 3835 & 308 & 8 & 3115 & 325 & 10 \\
\hline \multicolumn{13}{|l|}{ Philadelphia } \\
\hline Electricity $\left(\mathrm{kWh} / 1000 \mathrm{ft}^{2}\right)$ & 1848 & 78 & 4 & 2558 & 133 & 5 & 13951 & 672 & 5 & 3570 & 183 & 5 \\
\hline Natural Gas $\left(\mathrm{kBtu} / 1000 \mathrm{ft}^{2}\right)$ & 35474 & -1254 & -4 & 40483 & -1547 & -4 & 27508 & -6930 & -25 & 58859 & -2834 & -5 \\
\hline Net Energy $\left(\$ / 1000 \mathrm{ft}^{2}\right)$ & 431 & 2 & 0 & 545 & 7 & 1 & 1811 & 35 & 2 & 774 & 5 & 1 \\
\hline Peak $\left(W / 1000 \mathrm{ft}^{2}\right)$ & 3809 & 187 & 5 & 3302 & 214 & 6 & 4027 & 420 & 10 & 2158 & 278 & 13 \\
\hline \multicolumn{13}{|l|}{ Phoenix } \\
\hline Electricity $\left(\mathrm{kWh} / 1000 \mathrm{ft}^{2}\right)$ & 5639 & 329 & 6 & 5852 & 362 & 6 & 21042 & 1687 & 8 & 11934 & 1071 & 9 \\
\hline Natural Gas $\left(\mathrm{kBtu} / 1000 \mathrm{ft}^{2}\right)$ & 2477 & -300 & -12 & 5748 & -947 & -16 & 972 & -3164 & -326 & 1271 & -162 & -13 \\
\hline Net Energy $\left(\$ / 1000 \mathrm{ft}^{2}\right)$ & 531 & 29 & 5 & 568 & 28 & 5 & 1941 & 140 & 7 & 1104 & 98 & 9 \\
\hline Peak $\left(W / 1000 \mathrm{ft}^{2}\right)$ & 6521 & 76 & 1 & 5315 & 243 & 5 & 4630 & 483 & 10 & 4540 & 332 & 7 \\
\hline \multicolumn{13}{|l|}{ Washington DC } \\
\hline Electricity $\left(\mathrm{kWh} / 1000 \mathrm{ft}^{2}\right)$ & 2706 & 111 & 4 & 3119 & 145 & 5 & 14764 & 756 & 5 & 6738 & 443 & 7 \\
\hline Natural Gas $\left(\mathrm{kBtu} / 1000 \mathrm{ft}^{2}\right)$ & 20429 & -837 & -4 & 29929 & -1283 & -4 & 24395 & -6384 & -26 & 14097 & -951 & -7 \\
\hline Net Energy $\left(\$ / 1000 \mathrm{ft}^{2}\right)$ & 311 & 3 & 1 & 395 & 4 & 1 & 1190 & 14 & 1 & 560 & 26 & 5 \\
\hline Peak $\left(W / 1000 \mathrm{ft}^{2}\right)$ & 5155 & 88 & 2 & 4205 & 140 & 3 & 4128 & 448 & 11 & 3519 & 225 & 6 \\
\hline
\end{tabular}


Table B-19(Cont). DOE-2 simulated HVAC base use and savings from light-colored roofing; annual electricity and net energy, peak electricity demand, and annual natural gas estimated per $1000 \mathrm{ft}^{2}$ of flat roof area.

\begin{tabular}{|c|c|c|c|}
\hline \multirow{3}{*}{ Metropolitan Area } & \multicolumn{3}{|c|}{ Grocery Store } \\
\hline & \multirow{2}{*}{$\begin{array}{l}\text { Base } \\
\text { Case }\end{array}$} & \multicolumn{2}{|c|}{ Savings } \\
\hline & & $\bar{\Delta}$ & $\%$ \\
\hline \multicolumn{4}{|l|}{ Atlanta } \\
\hline Electricity $\left(\mathrm{kWh} / 1000 \mathrm{ft}^{2}\right)$ & 9189 & 245 & 3 \\
\hline Natural Gas $\left(\mathrm{kBtu} / 1000 \mathrm{ft}^{2}\right)$ & 31024 & -451 & -1 \\
\hline Net Energy $\left(\$ / 1000 \mathrm{ft}^{2}\right)$ & 860 & 15 & 2 \\
\hline Peak $\left(W / 1000 \mathrm{ft}^{2}\right)$ & 5675 & 262 & 5 \\
\hline \multicolumn{4}{|l|}{ Chicago } \\
\hline Electricity $\left(\mathrm{kWh} / 1000 \mathrm{ft}^{2}\right)$ & 8092 & 152 & 2 \\
\hline Natural Gas $\left(\mathrm{kBtu} / 1000 \mathrm{ft}^{2}\right)$ & 85447 & -970 & -1 \\
\hline Net Energy $\left(\$ / 1000 \mathrm{ft}^{2}\right)$ & 1116 & 8 & 1 \\
\hline Peak $\left(W / 1000 \mathrm{ft}^{2}\right)$ & 5690 & 129 & 2 \\
\hline \multicolumn{4}{|l|}{ Los Angeles } \\
\hline Electricity $\left(\mathrm{kWh} / 1000 \mathrm{ft}^{2}\right)$ & 8561 & 337 & 4 \\
\hline Natural Gas $\left(\mathrm{kBtu} / 1000 \mathrm{ft}^{2}\right)$ & 12613 & -203 & -2 \\
\hline Net Energy $\left(\$ / 1000 \mathrm{ft}^{2}\right)$ & 838 & 29 & 3 \\
\hline Peak $\left(W / 1000 \mathrm{ft}^{2}\right)$ & 5296 & 162 & 3 \\
\hline \multicolumn{4}{|l|}{ Fort Worth } \\
\hline Electricity $\left(\mathrm{kWh} / 1000 \mathrm{ft}^{2}\right)$ & 13394 & 297 & 2 \\
\hline Natural Gas $\left(\mathrm{kBtu} / 1000 \mathrm{ft}^{2}\right)$ & 23985 & -316 & -1 \\
\hline Net Energy $\left(\$ / 1000 \mathrm{ft}^{2}\right)$ & 963 & 18 & 2 \\
\hline Peak $\left(W / 1000 \mathrm{ft}^{2}\right)$ & 7331 & 203 & 3 \\
\hline \multicolumn{4}{|l|}{ Houston } \\
\hline Electricity $\left(\mathrm{kWh} / 1000 \mathrm{ft}^{2}\right)$ & 11027 & 258 & 2 \\
\hline Natural Gas $\left(\mathrm{kBtu} / 1000 \mathrm{ft}^{2}\right)$ & 15704 & -181 & -1 \\
\hline Net Energy $\left(\$ / 1000 \mathrm{ft}^{2}\right)$ & 907 & 19 & 2 \\
\hline Peak $\left(W / 1000 \mathrm{ft}^{2}\right)$ & 6241 & 158 & 3 \\
\hline \multicolumn{4}{|l|}{ Miami } \\
\hline Electricity $\left(\mathrm{kWh} / 1000 \mathrm{ft}^{2}\right)$ & 16263 & 397 & 2 \\
\hline Natural Gas $\left(\mathrm{kBtu} / 1000 \mathrm{ft}^{2}\right)$ & 8258 & -23 & 0 \\
\hline Net Energy $\left(\$ / 1000 \mathrm{ft}^{2}\right)$ & 1154 & 27 & 2 \\
\hline Peak $\left(W / 1000 \mathrm{ft}^{2}\right)$ & 5959 & 165 & 3 \\
\hline
\end{tabular}

\begin{tabular}{|l||r|r|r|}
\hline \multicolumn{1}{|c||}{} & \multicolumn{3}{|c|}{ Grocery Store } \\
\cline { 2 - 4 } Metropolitan Area & \multicolumn{1}{|c|}{ Base } & \multicolumn{2}{|c|}{ Savings } \\
\cline { 3 - 4 } & \multicolumn{1}{|c|}{ Case } & \multicolumn{1}{|c|}{$\%$} \\
\hline \hline New Orleans & & & \\
Electricity $\left(\mathrm{kWh} / 1000 \mathrm{ft}^{2}\right)$ & 10518 & 291 & 3 \\
Natural Gas $\left(\mathrm{kBtu} / 1000 \mathrm{ft}^{2}\right)$ & 14621 & -181 & -1 \\
Net Energy $\left(\$ / 1000 \mathrm{ft}^{2}\right)$ & 961 & 23 & 2 \\
Peak $\left(W / 1000 \mathrm{ft}^{2}\right)$ & 5388 & 169 & 3 \\
New York City & & & \\
Electricity $\left(\mathrm{kWh} / 1000 \mathrm{ft}^{2}\right)$ & 7768 & 132 & 2 \\
Natural Gas $\left(\mathrm{kBtu} / 1000 \mathrm{ft}^{2}\right)$ & 65501 & -654 & -1 \\
Net Energy $\left(\$ / 1000 \mathrm{ft}^{2}\right)$ & 1385 & 13 & 1 \\
Peak $\left(W / 1000 \mathrm{ft}^{2}\right)$ & 5456 & 140 & 3 \\
Philadelphia & & & \\
Electricity $\left(\mathrm{kWh} / 1000 \mathrm{ft}^{2}\right)$ & 7669 & 139 & 2 \\
Natural Gas $\left(\mathrm{kBtu} / 1000 \mathrm{ft}^{2}\right)$ & 127911 & -1895 & -1 \\
Net Energy $\left(\$ / 1000 \mathrm{ft}^{2}\right)$ & 1672 & 5 & 0 \\
Peak $\left(W / 1000 \mathrm{ft}^{2}\right)$ & 4713 & 187 & 4 \\
Phoenix & & & \\
Electricity $\left(\mathrm{kWh} / 1000 \mathrm{ft}^{2}\right)$ & 18954 & 555 & 3 \\
Natural Gas $\left(\mathrm{kBtu} / 1000 \mathrm{ft}^{2}\right)$ & 12432 & -135 & -1 \\
Net Energy $\left(\$ / 1000 \mathrm{ft}^{2}\right)$ & 1807 & 50 & 3 \\
Peak $\left(W / 1000 \mathrm{ft}^{2}\right)$ & 8802 & 203 & 2 \\
Washington DC & & & \\
Electricity $\left(\mathrm{kWh} / 1000 \mathrm{ft}^{2}\right)$ & 8780 & 278 & 3 \\
Natural Gas $\left(\mathrm{kBtu} / 1000 \mathrm{ft}^{2}\right)$ & 49774 & -722 & -1 \\
Net Energy $\left(\$ / 1000 \mathrm{ft}^{2}\right)$ & 912 & 16 & 2 \\
Peak $\left(W / 1000 \mathrm{ft}^{2}\right)$ & 5722 & 269 & 5 \\
\hline \multicolumn{2}{|c|}{} & &
\end{tabular}



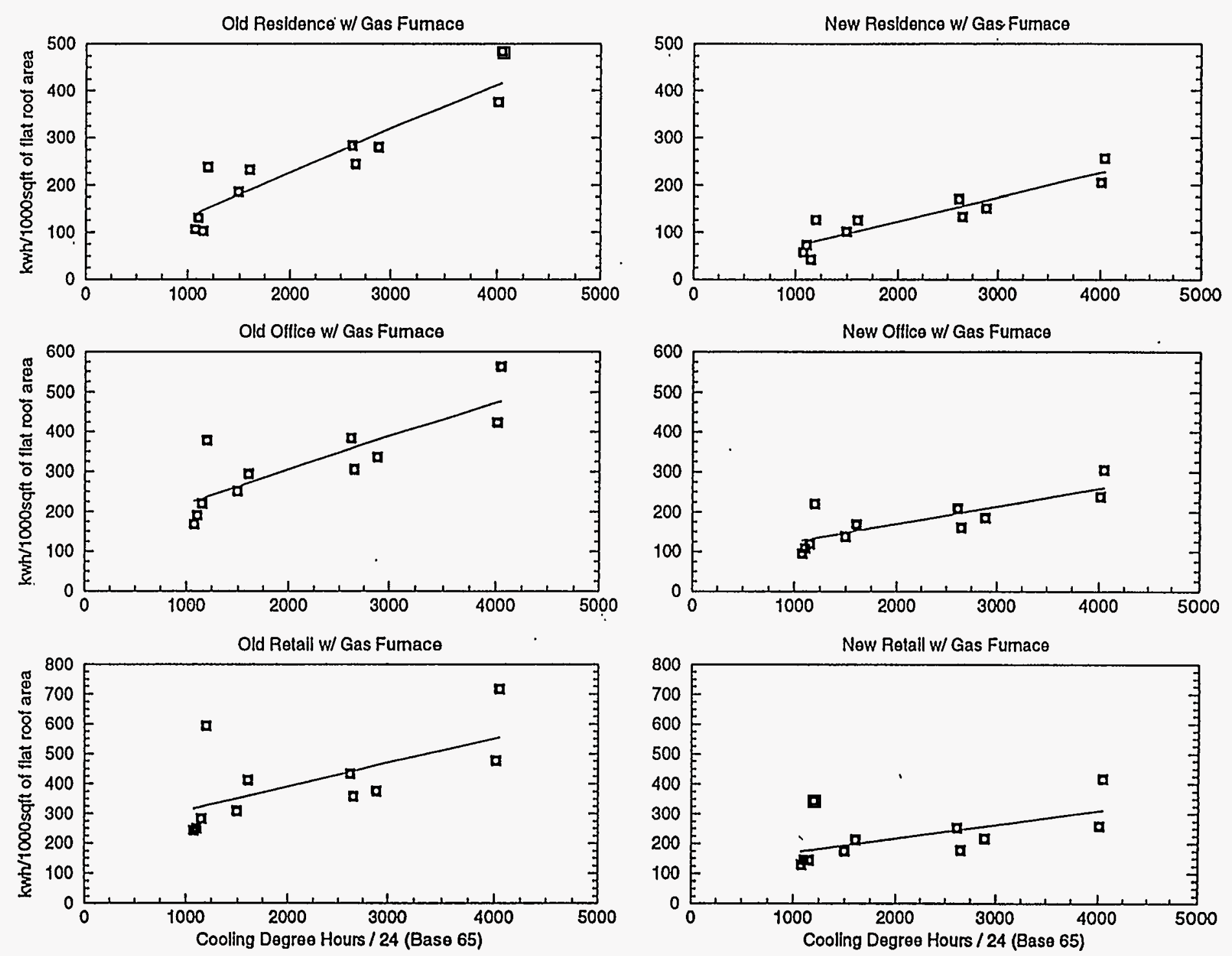

Figure B-1(a). DOE-2 simulated HVAC annual electricity savings from light-colored roofing shown versus cooling degree days. 

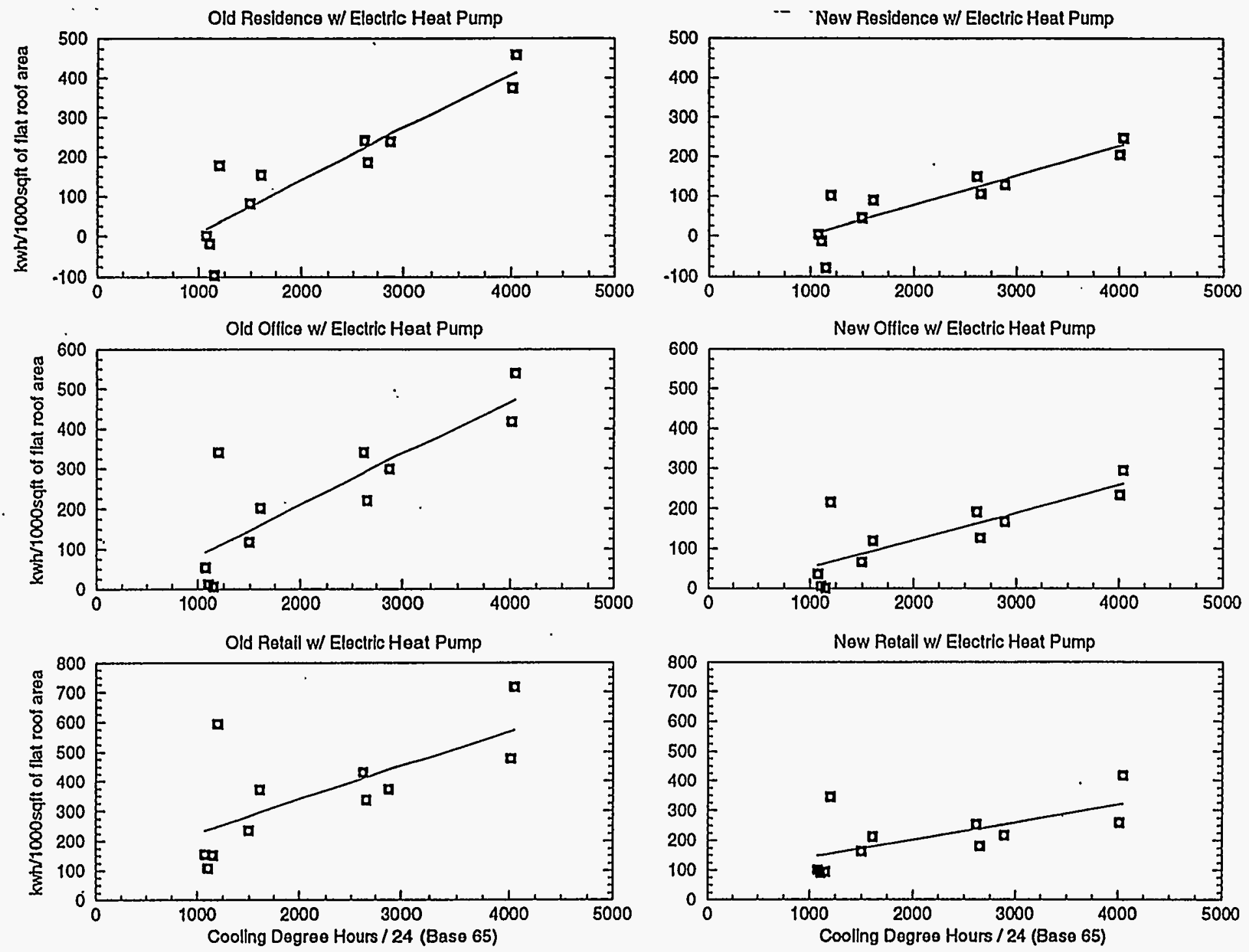

Figure B-1(b). DOE-2 simulated HVAC annual electricity savings from light-colored roofing shown versus cooling degree days. 

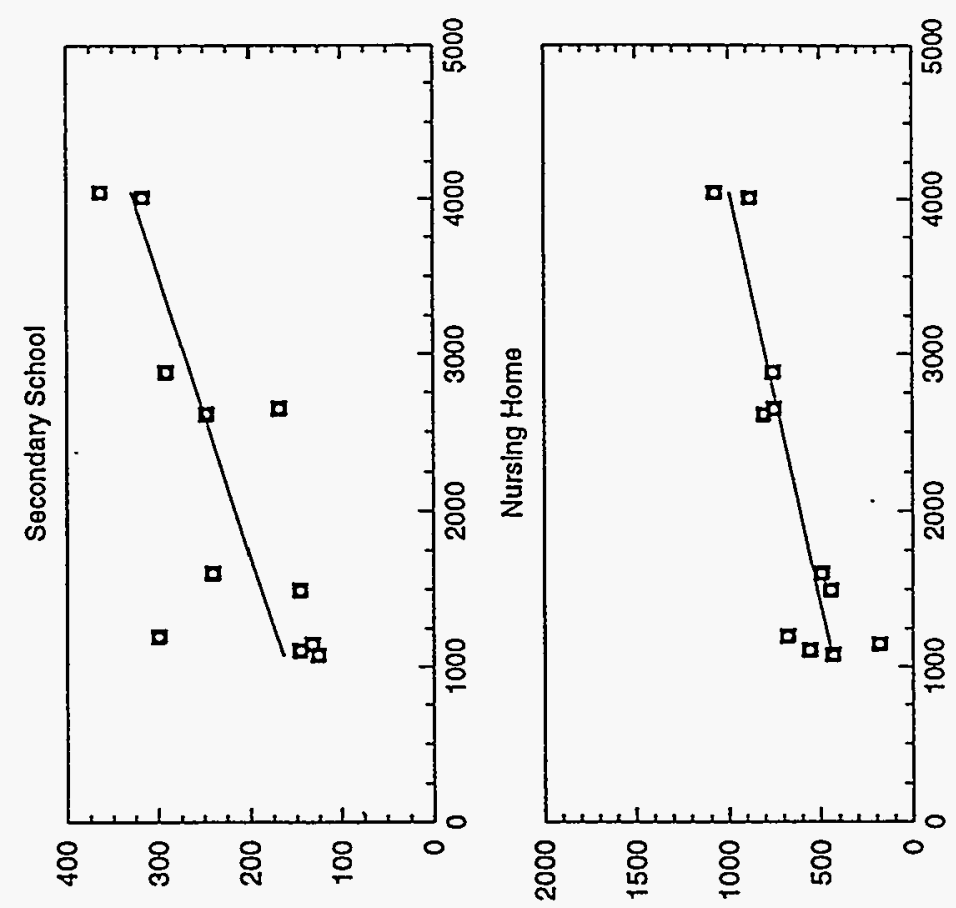

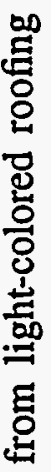

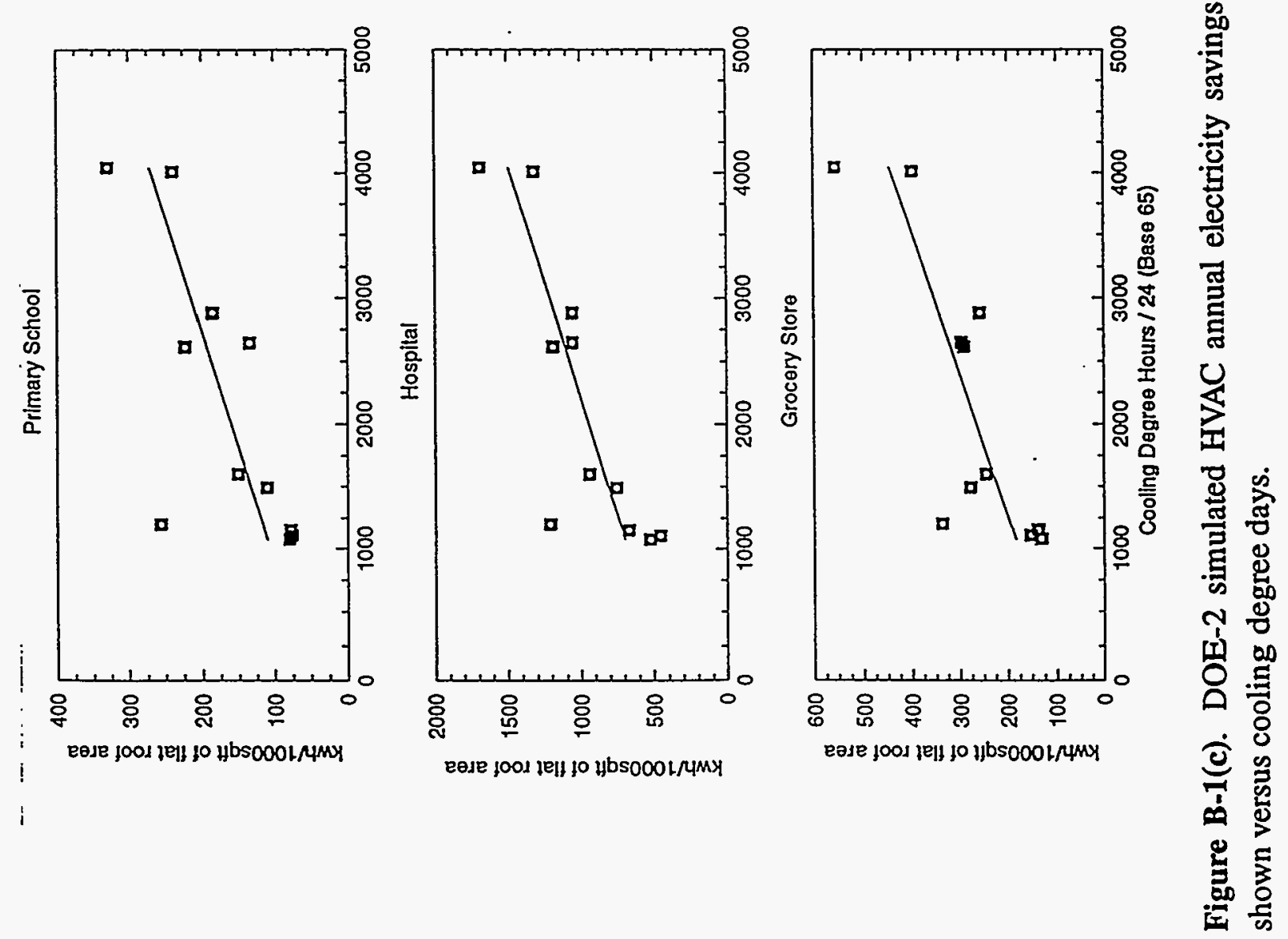



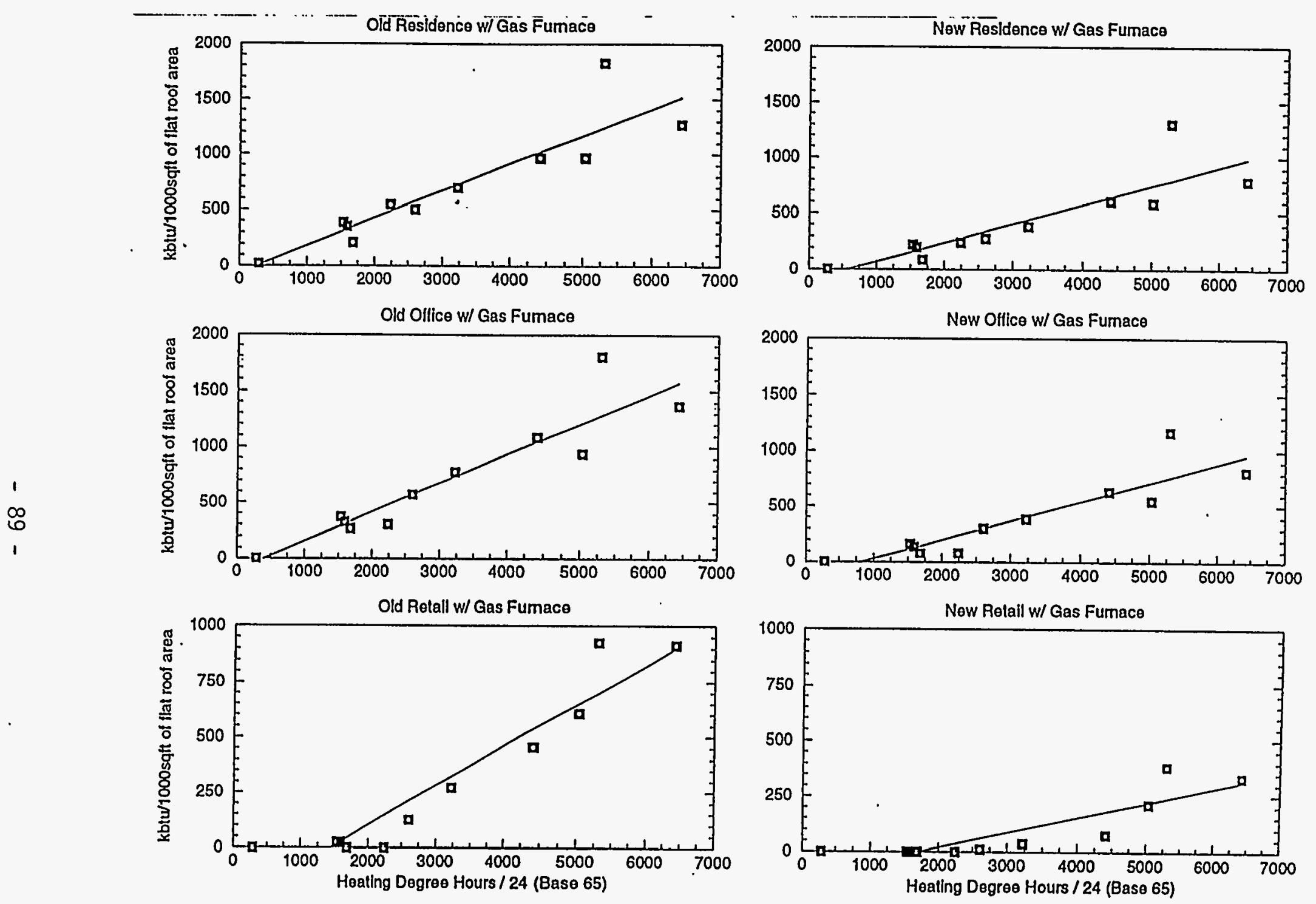

Figure B-2(a). DOE-2 simulated HVAC annual natural gas deficit from light-colored roofing shown versus heating degree days. 

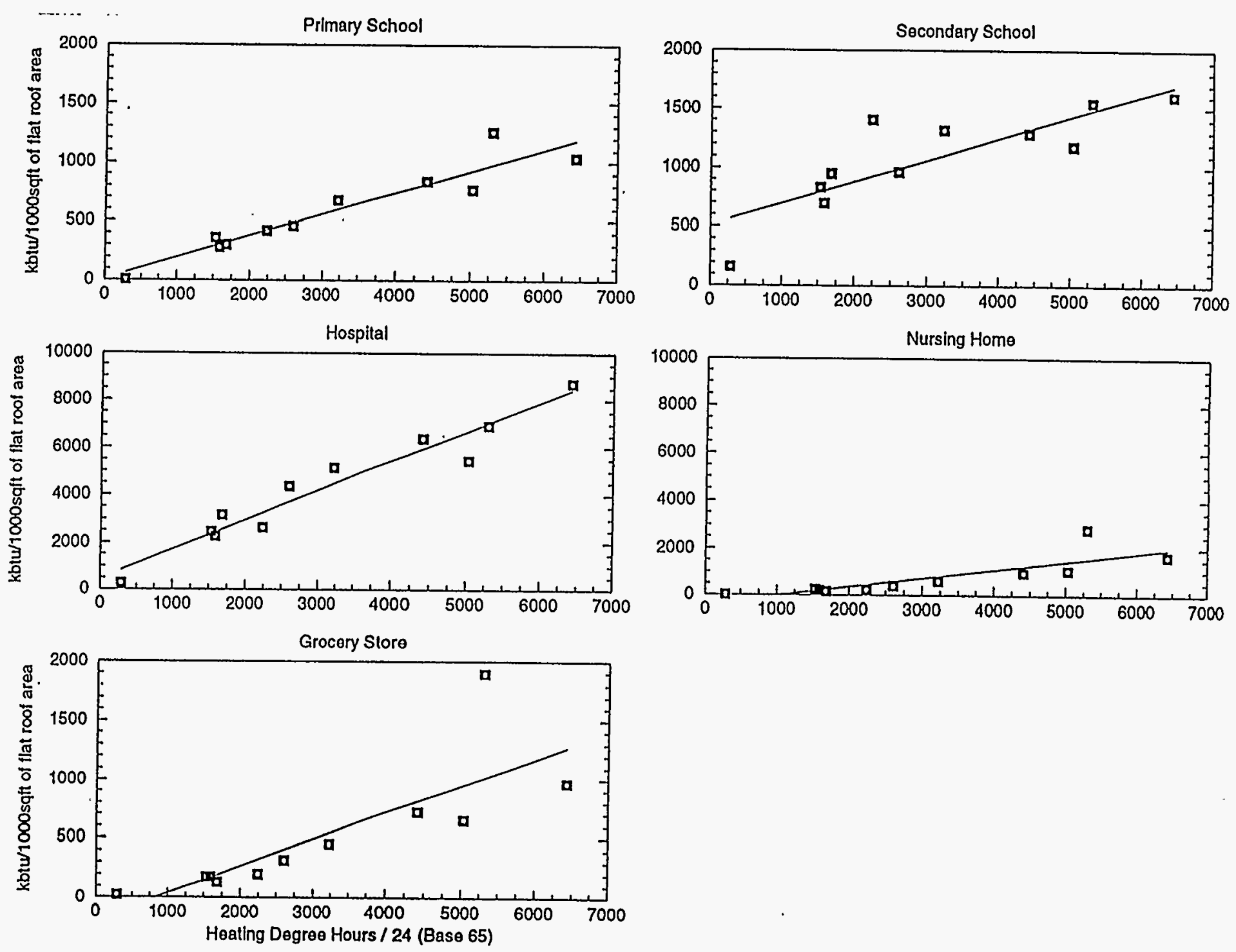

Figure B-2(b). DOE-2 simulated HVAC annual natural gas deficit from light-colored roofing shown versus heating degree days. 

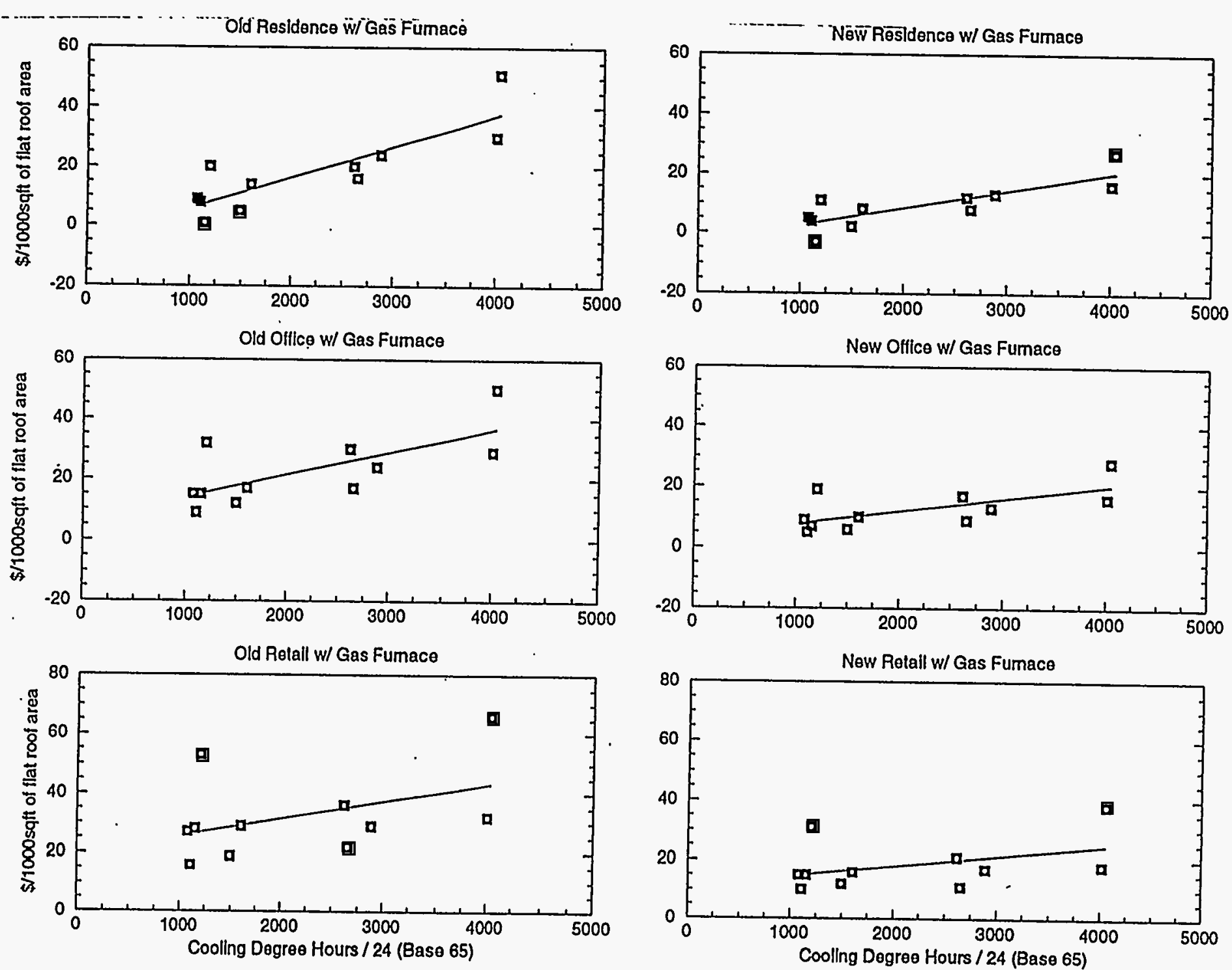

Figure B-3(a). DOE-2 simulated HVAC annual net energy savings from light-colored roofing shown versus cooling degree days. 

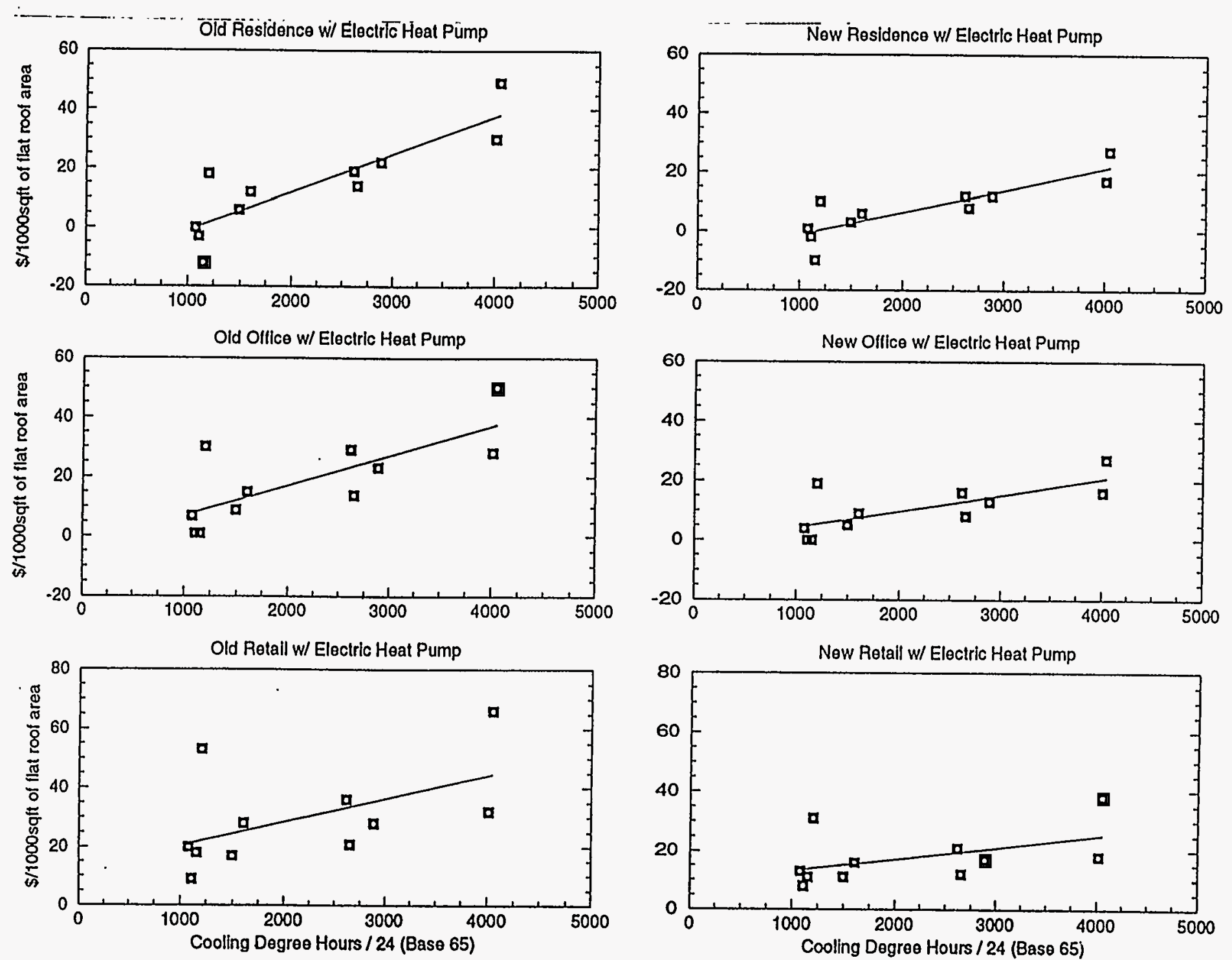

Figure B-3(b). DOE-2 simulated HVAC annual net energy savings from light-colored roofing shown versus cooling degree days. 

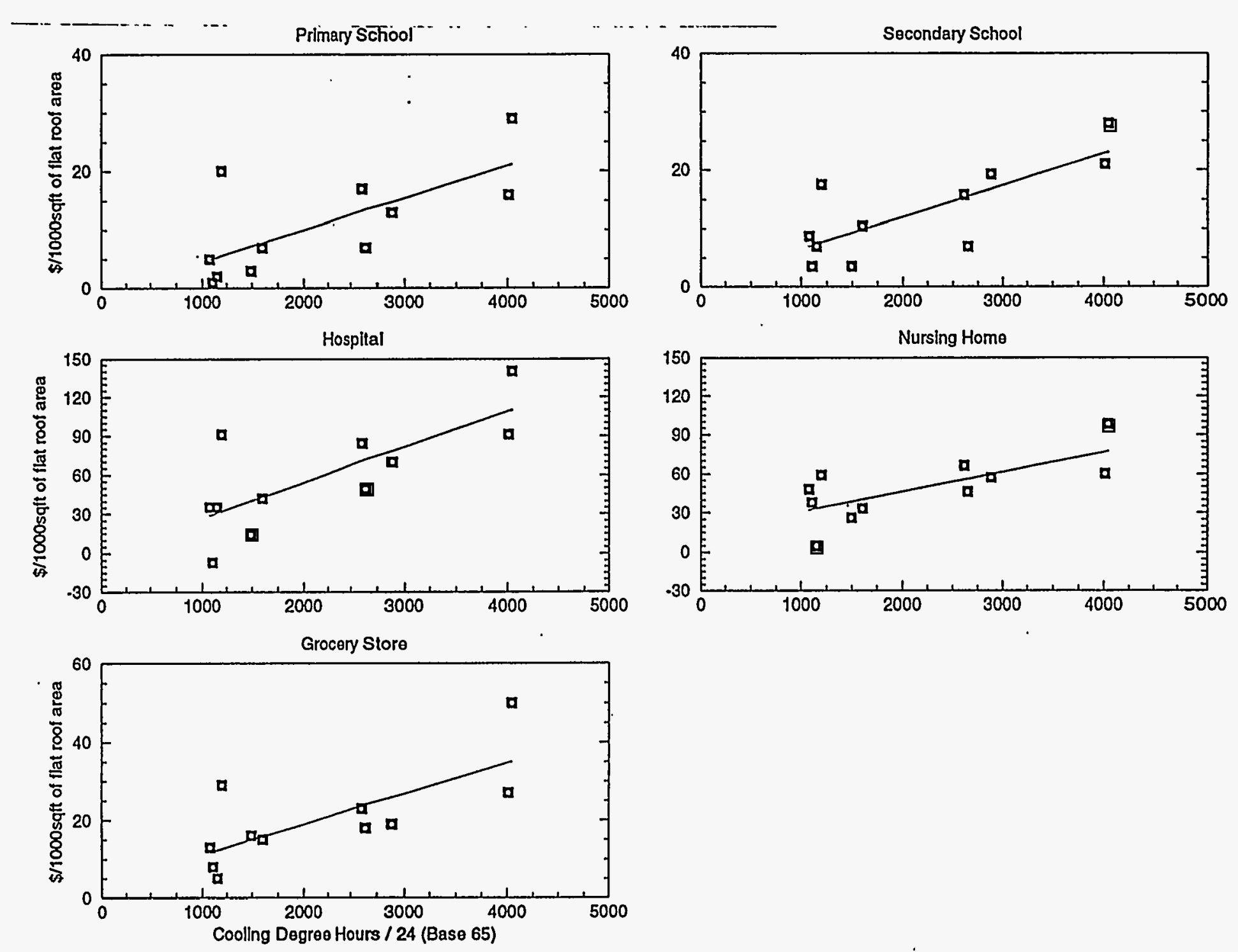

Figure B-3(c). DOE-2 simulated HVAC annual net energy savings from light-colored roofing shown versus cooling degree days. 

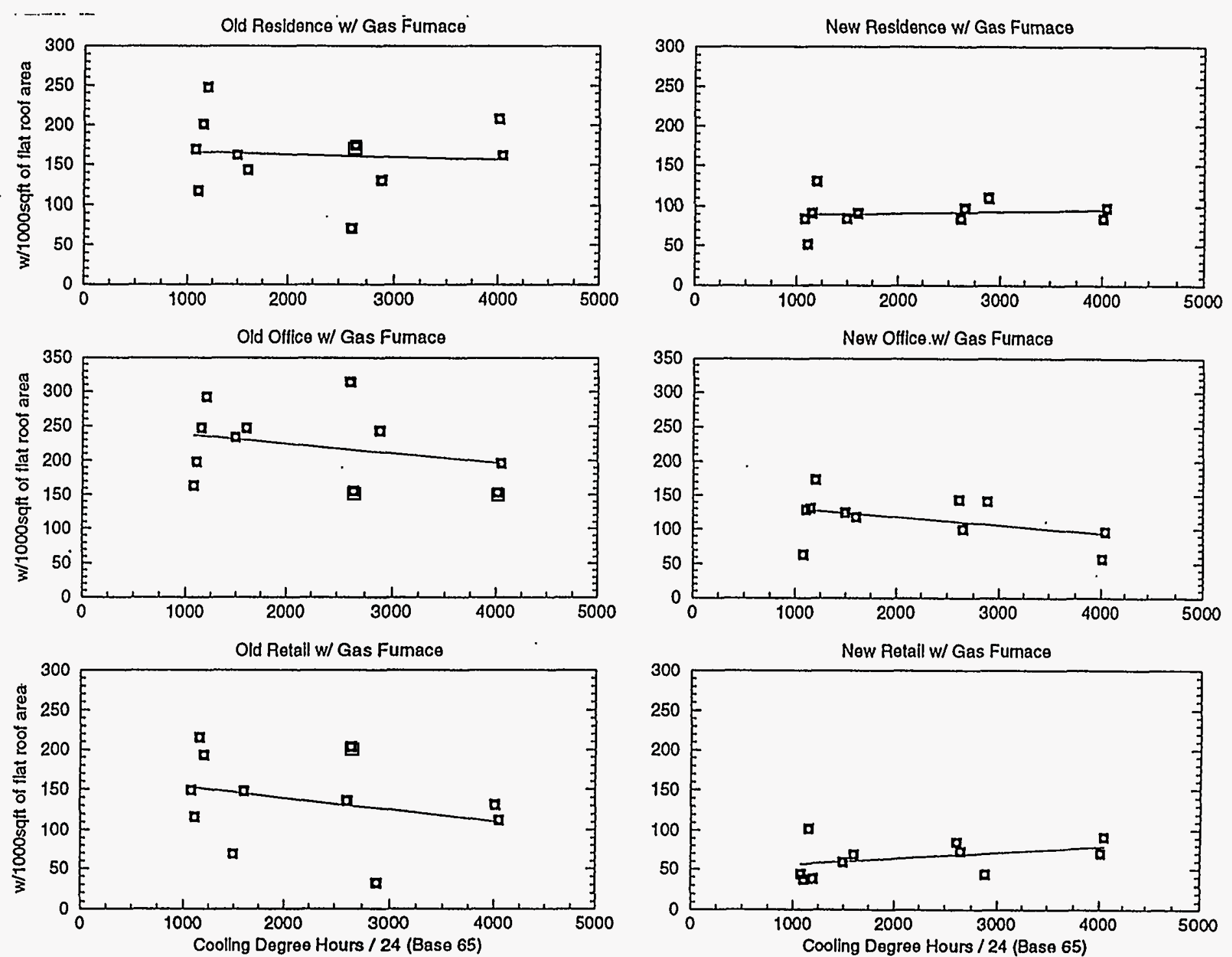

Figure B-4(a). DOE-2 simulated HVAC peak electricity demand savings from light-colored roofing shown versus cooling degree days. 

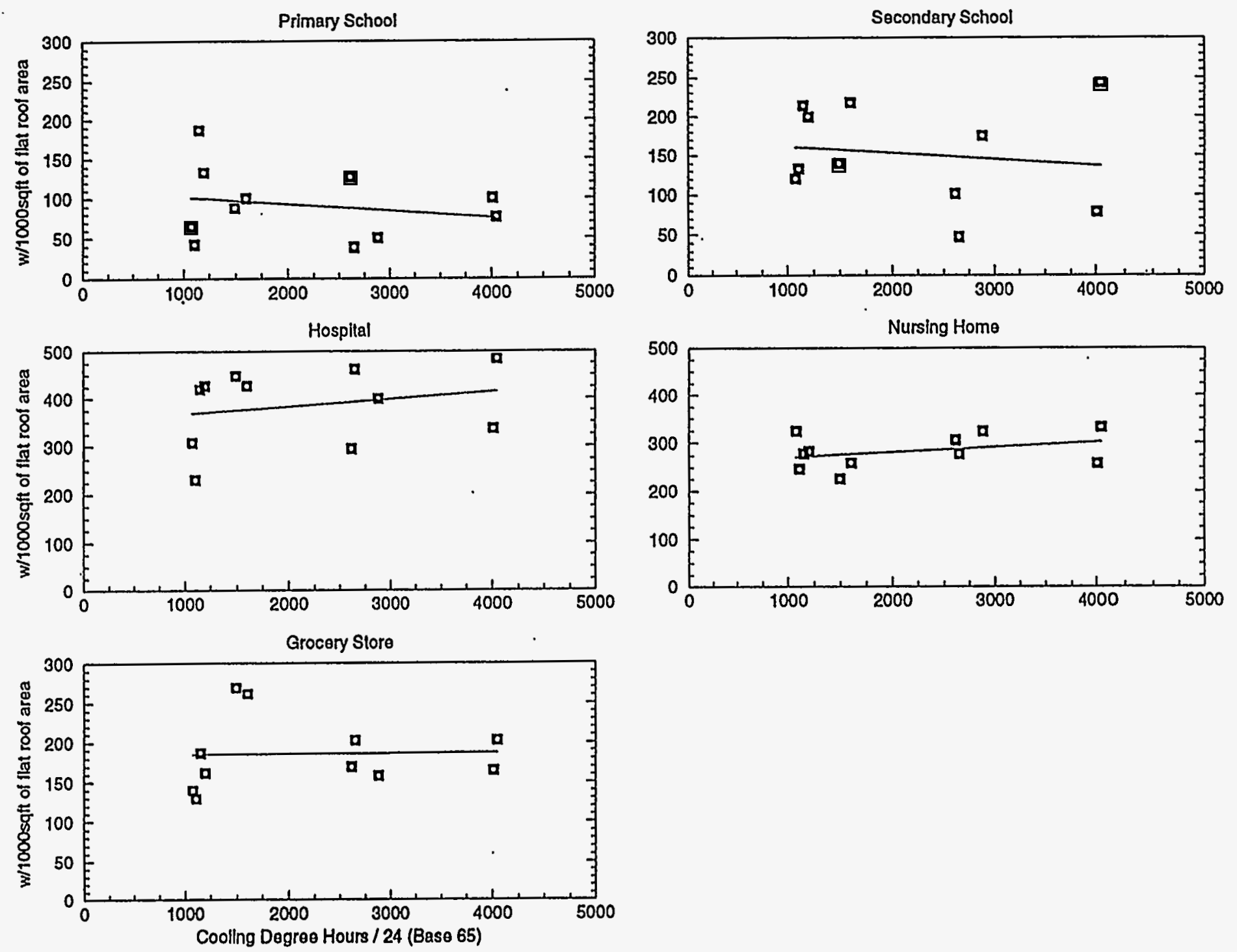

Figure B-4(b). DOE-2 simulated HVAC peak electricity demand savings from light-colored roofing shown versus cooling degree days. 


\section{Building Stock and Roof Area Data}

This appendix contains data used in the calculation of residential and commercial conditioned flat roof area described within Chapter 4. Table $\mathbf{C}-\mathbf{1}$ shows data extracted from the American Housing Survey (AHS); i.e., number of housing units, average number of floors, and median floor area, for the calculation of residential conditioned flat roof area for old and new vintages. Table $\mathbf{C}-2$ displays the population of each each census division, which supplement the CBECS data for the estimation of commercial conditioned flat roof area. Air-conditioning (heat pump) and gas furnace saturations for each building and location are in Table C-3 with the total and conditioned flat roof area. 
Table C-1. Residential building stock data for determination of conditioned flat roof area (Source: AHS).

\begin{tabular}{|c|c|c|c|c|c|c|c|c|c|}
\hline \multirow{2}{*}{ Metropolitan Area } & \multicolumn{3}{|c|}{ \# Housing Units (1000s) } & \multicolumn{2}{|c|}{ Average \# Floors } & \multicolumn{2}{|c|}{ Median Floor Area $\left(\mathrm{ft}^{2}\right)$} & \multicolumn{2}{|c|}{ Total Roof Area $\left(\mathrm{Mft}^{2}\right)$} \\
\hline & total & pre-1980 & $1980-1990$ & pre- 1980 & $1980-1990$ & pre- 1980 & $1980-1990$ & pre- 1980 & $1980-1990$ \\
\hline Atlanta & 1172.6 & 784.1 & 388.5 & 1.9 & 2.3 & 1642 & 2078 & 677.6 & 351.0 \\
\hline Chicago & 2815.9 & 2547.1 & 268.8 & 3.1 & 3.0 & 1736 & 2770 & 1426.4 & 248.2 \\
\hline Los Angeles & 5293.1 & 4850.9 & 442.2 & 1.6 & 2.2 & 1258 & 1596 & 3814.0 & 320.8 \\
\hline Dallas/Ft Worth & 1696.3 & 1202.0 & 494.3 & 1.5 & 1.8 & 1463 & 2065 & 1172.4 & 567.1 \\
\hline Houston & 1430.6 & 1090.8 & 339.8 & 1.5 & 2.1 & 1568 & 2373 & 1140.2 & 384.0 \\
\hline Miami/Ft Lauderdale & 1502.1 & 1181.6 & 320.5 & 2.3 & 2.2 & 1436 & 2266 & 737.7 & 330.1 \\
\hline New Orleans & 583.9 & 460.4 & 123.5 & 1.5 & 1.5 & 1437 & 2071 & 441.1 & 170.5 \\
\hline New York & 7096.7 & 6757.4 & 339.3 & 4.5 & 4.0 & 1728 & 2856 & 2594.8 & 242.3 \\
\hline Philadelphia & 1937.1 & 1753.5 & 183.6 & 3.0 & 2.8 & 2343 & 2721 & 1369.5 & 178.4 \\
\hline Phoenix & 985.3 & 603.4 & 381.9 & 1.3 & 1.7 & 1355 & 1915 & 628.9 & 430.2 \\
\hline DC/Baltimore & 2498.4 & 2029.9 & 468.5 & 3.0 & 3.1 & 1911 & 2784 & 1293.0 & 420.7 \\
\hline
\end{tabular}


Table C-2. Metropolitan area and census division population for calculation of commercial conditioned flat roof area (CBECS, 1994).

\begin{tabular}{|l|c||l|c||c|}
\hline Metropolitan Area & $\begin{array}{c}\text { Population } \\
\text { (Millions) }\end{array}$ & Census Division & $\begin{array}{c}\text { Population } \\
\text { (Millions) }\end{array}$ & $\begin{array}{c}\text { Percent of } \\
\text { Division Population }\end{array}$ \\
\hline \hline Atlanta & 2.8 & South Atlantic & 41.3 & 6.9 \\
Chicago & 8.1 & East North Central & 41.7 & 19.3 \\
Los Angeles & 14.5 & Pacific & 39.2 & 37.1 \\
Dallas/Ft Worth & 3.9 & West South Central & 25.8 & 15.1 \\
Houston & 3.7 & West South Central & 25.8 & 14.4 \\
Miami/Ft Lauderdale & 3.2 & South Atlantic & 41.3 & 7.7 \\
New Orleans & 1.2 & West South Central & 25.8 & 4.8 \\
New York & 18.1 & Middle Atlantic & 39.6 & 45.7 \\
Philadelphia & 5.9 & Middle Atlantic & 39.6 & 14.9 \\
Phoenix & 2.1 & Mountain & 13.2 & 16.1 \\
DC/Baltimore & 6.3 & South Atlantic & 41.3 & 15.3 \\
\hline
\end{tabular}


Table C-3. Total and conditioned flat roof area of residential and commercial building stock.

\begin{tabular}{|c|c|c|c|c|c|c|}
\hline \multirow{2}{*}{ metropolitan area } & \multirow{2}{*}{$\begin{array}{c}\text { total flat roof area } \\
{\left[\mathrm{Mft}^{2}\right]}\end{array}$} & \multicolumn{3}{|c|}{ HVAC saturation [\%] } & \multicolumn{2}{|c|}{ conditioned flat roof area $\left[\mathrm{Mft}^{2}\right]$} \\
\hline & & ac & gas & hp & ac \& gas & $\mathrm{ac} / \mathrm{hp}$ \\
\hline \multicolumn{7}{|l|}{ Residence Old } \\
\hline Atlanta & 677.6 & 72 & 93 & 7 & 453.7 & 34.2 \\
\hline Chicago & 1426.4 & 39 & 98 & 2 & 545.2 & 11.1 \\
\hline Los Angeles & 3814.0 & 25 & 100 & 0 & 953.5 & 0.0 \\
\hline Dallas/Ft Worth & 1172.4 & 76 & 96 & 4 & 855.4 & 35.6 \\
\hline Houston & 1140.2 & 76 & 91 & 9 & 788.6 & 78.0 \\
\hline Miami/Ft Lauderdale & 737.7 & 72 & 48 & 52 & 254.9 & 276.2 \\
\hline New Orleans & 441.1 & 59 & 97 & 3 & 252.4 & 7.8 \\
\hline New York & 2594.8 & 9 & 99 & 1 & 231.2 & 2.3 \\
\hline Philadelphia & 1369.5 & 29 & 95 & 5 & 377.3 & 19.9 \\
\hline Phoenix & 628.9 & 85 & 65 & 35 & 347.5 & 187.1 \\
\hline DC/Baltimore & 1293.0 & 71 & 78 & 22 & 716.1 & 202.0 \\
\hline \multicolumn{7}{|l|}{ Residence New } \\
\hline Atlanta & 351.0 & 94 & 81 & 19 & 267.3 & 62.7 \\
\hline Chicago & 248.2 & 84 & 96 & 4 & 200.1 & 8.3 \\
\hline Los Angeles & 320.8 & 62 & 97 & 3 & 192.9 & 6.0 \\
\hline Dallas/Ft Worth & 567.1 & 99 & 94 & 6 & 527.7 & 33.7 \\
\hline Houston & 384.0 & 94 & 86 & 14 & 310.4 & 50.5 \\
\hline Miami/Ft Lauderdale & 330.1 & 98 & 32 & 68 & 103.5 & 220.0 \\
\hline New Orleans & 170.5 & 95 & 86 & 14 & 139.3 & 22.7 \\
\hline New York & 242.3 & 43 & 99 & 1 & 103.1 & 1.0 \\
\hline Philadelphia & 178.4 & 81 & 69 & 31 & 99.7 & 44.8 \\
\hline Phoenix & 430.2 & 97 & 42 & 58 & 175.3 & 242.0 \\
\hline DC/Baltimore & 420.7 & 97 & 62 & 38 & 253.0 & 155.1 \\
\hline \multicolumn{7}{|l|}{ Office Old } \\
\hline Atlanta & 27.5 & 100 & 69 & 31 & 19.0 & 8.5 \\
\hline Chicago & 93.5 & 95 & 94 & 6 & 83.5 & 5.3 \\
\hline Los Angeles & 168.2 & 93 & 92 & 8 & 143.9 & 12.5 \\
\hline Dallas/Ft Worth & 53.1 & 100 & 95 & 5 & 50.4 & 2.7 \\
\hline Houston & 50.8 & 100 & 95 & 5 & 48.3 & 2.5 \\
\hline Miami/Ft Lauderdale & 31.0 & 100 & 69 & 31 & 21.4 & 9.6 \\
\hline New Orleans & 19.3 & 100 & 95 & 5 & 18.3 & 1.0 \\
\hline New York & 111.9 & 92 & 88 & 12 & $90.6^{\circ}$ & 12.4 \\
\hline Philadelphia & 36.6 & 92 & 88 & 12 & 29.6 & 4.0 \\
\hline Phoenix & 12.1 & 100 & 86 & 14 & 10.4 & 1.7 \\
\hline DC/Baltimore & 61.5 & 100 & 69 & 31 & 42.4 & 19.1 \\
\hline \multicolumn{7}{|l|}{ Office New } \\
\hline Atlanta & 8.7 & 100 & 45 & 55 & 3.9 & 4.8 \\
\hline Chicago & 31.6 & 100 & 95 & 5 & 30.0 & 1.6 \\
\hline Los Angeles & 100.0 & 100 & 72 & 28 & 72.0 & 28.0 \\
\hline Dallas/Ft Worth & 33.5 & 100 & 85 & 15 & 28.5 & 5.0 \\
\hline Houston & 32.1 & 100 & 85 & 15 & 27.3 & 4.8 \\
\hline Miami/Ft Lauderdale & 9.7 & 100 & 45 & 55 & 4.4 & 5.3 \\
\hline New Orleans & 12.2 & 100 & 85 & 15 & 10.4 & 1.8 \\
\hline New York & 48.4 & 100 & 72 & 28 & 34.8 & 13.6 \\
\hline Philadelphia & 15.8 & 100 & 72 & 28 & 11.4 & 4.4 \\
\hline Phoenix & 22.9 & 100 & 72 & 28 & 16.5 & 6.4 \\
\hline DC/Baltimore & 18.9 & 100 & 45 & 55 & 8.5 & 10.4 \\
\hline
\end{tabular}


Table C-3(Cont). Total and conditioned flat roof area of residential and commercial building stock.

\begin{tabular}{|c|c|c|c|c|c|c|}
\hline \multirow{2}{*}{ metropolitan area } & \multirow{2}{*}{$\begin{array}{c}\text { total flat roof area } \\
{\left[\mathrm{Mft}^{2}\right]}\end{array}$} & \multicolumn{3}{|c|}{ HVAC saturation [\%] } & \multicolumn{2}{|c|}{ conditioned flat roof area $\left[\mathrm{Mft}^{2}\right]$} \\
\hline & & ac & gas & $\mathrm{hp}$ & ac \& gas & ac/hp \\
\hline \multicolumn{7}{|l|}{ Retail Store Old } \\
\hline Atlanta & 22.3 & 79 & 82 & 18 & 14.4 & 3.2 \\
\hline Chicago & 132.2 & 63 & 100 & 0 & 83.3 & 0.0 \\
\hline Los Angeles & 228.1 & 64 & 94 & 6 & 137.2 & 8.8 \\
\hline Dallas/Ft Worth & 117.2 & 85 & 95 & 5 & 94.6 & 5.0 \\
\hline Houston & 111.9 & 85 & 95 & 5 & 90.4 & 4.8 \\
\hline Miami/Ft Lauderdale & 25.2 & 79 & 82 & 18 & 16.3 & 3.6 \\
\hline New Orleans & 42.5 & 85 & 95 & 5 & 34.3 & 1.8 \\
\hline New York & 333.7 & 70 & 97 & 3 & 226.6 & 7.0 \\
\hline Philadelphia & 109.3 & 70 & 97 & 3 & 74.2 & 2.3 \\
\hline Phoenix & 15.4 & 78 & 99 & 1 & 11.9 & 0.1 \\
\hline DC/Baltimore & 50.2 & 79 & 82 & 18 & 32.5 & 7.1 \\
\hline \multicolumn{7}{|l|}{ Retail Store New } \\
\hline Atlanta & 13.1 & 71 & 75 & 25 & 7.0 & 2.3 \\
\hline Chicago & 58.5 & 69 & 99 & 1 & 40.0 & 0.4 \\
\hline Los Angeles & 70.8 & 85 & 86 & 14 & 51.8 & 8.4 \\
\hline Dallas/Ft Worth & 25.2 & 79 & 100 & 0 & 19.9 & 0.0 \\
\hline Houston & 24.0 & 79 & 100 & 0 & 19.0 & 0.0 \\
\hline Miami/Ft Lauderdale & 14.6 & 71 & 75 & 25 & 7.8 & 2.6 \\
\hline New Orleans & 9.1 & 79 & 100 & 0 & 7.2 & 0.0 \\
\hline New York & 72.4 & 69 & 99 & 1 & 49.5 & 0.5 \\
\hline Philadelphia & 23.8 & 69 & 99 & 1 & 16.3 & 0.2 \\
\hline Phoenix & 56.5 & 69 & 65 & 35 & 25.3 & 13.6 \\
\hline DC/Baltimore & 28.4 & 71 & 75 & 25 & 15.1 & 5.0 \\
\hline \multicolumn{7}{|l|}{ School } \\
\hline Atlanta & 32.7 & 99 & 72 & & 23.3 & \\
\hline Chicago & 118.8 & 74 & 99 & & 87.0 & \\
\hline Los Angeles & 142.0 & 63 & 90 & & 80.5 & \\
\hline Dallas/Ft Worth & 101.6 & 95 & 94 & & 90.7 & \\
\hline Houston & 96.9 & 95 & 94 & & 86.5 & \\
\hline Miami/Ft Lauderdale & 36.8 & 99 & 72 & & 26.2 & \\
\hline New Orleans & 36.9 & 95 & 94 & & 33.0 & \\
\hline New York & 179.3 & 85 & 95 & & 144.8 & \\
\hline Philadelphia & 58.8 & 85 & 95 & & 47.5 & \\
\hline Phoenix & 41.3 & 98 & 89 & & 36.0 & \\
\hline DC/Baltimore & 72.9 & 99 & 72 & & 52.0 & \\
\hline \multicolumn{7}{|l|}{ Hospital } \\
\hline Atlanta & 4.4 & 100 & 98 & & 4.3 & \\
\hline Chicago & 10.1 & 86 & 98 & & 8.5 & \\
\hline Los Angeles & 24.5 & 100 & 84 & & 20.6 & \\
\hline Dallas/Ft Worth & 9.3 & 40 & 100 & & 3.7 & \\
\hline Houston & 8.8 & 40 & 100 & & 3.5 & \\
\hline Miami/Ft Lauderdale & 4.7 & 100 & 98 & & 4.6 & \\
\hline New Orleans & 3.4 & 40 & 100 & & 1.4 & \\
\hline New York & 16.3 & 51 & 85 & & 7.1 & \\
\hline Philadelphia & 5.3 & 51 & 85 & & 2.3 & \\
\hline Phoenix & 2.5 & 100 & 100 & & 2.5 & \\
\hline DC/Baltimore & 9.5 & 100 & 98 & & 9.3 & \\
\hline
\end{tabular}


Table C-3(Cont). Total and conditioned flat roof area of residential and commercial building stock.

\begin{tabular}{|c|c|c|c|c|c|c|}
\hline \multirow{2}{*}{ metropolitan area } & \multirow{2}{*}{$\begin{array}{l}\text { total flat roof area } \\
{\left[\mathrm{Mft}^{2}\right]}\end{array}$} & \multicolumn{3}{|c|}{ HVAC saturation [\%] } & \multicolumn{2}{|c|}{ conditioned flat roof area $\left[\mathrm{Mft}^{2}\right]$} \\
\hline & & $\mathrm{ac}$ & gas & $\mathrm{hp}$ & ac \& gas & $\mathrm{ac} / \mathrm{hp}$ \\
\hline Nursing Home & & & & & & \\
\hline Atlanta & 2.2 & 24 & 89 & & 0.5 & \\
\hline Chicago & 22.4 & 97 & 90 & & 19.6 & \\
\hline Los Angeles & 13.0 & 100 & 100 & & 13.0 & \\
\hline Dallas/Ft Worth & 7.3 & 100 & 92 & & 6.7 & \\
\hline Houston & 7.1 & 100 & 92 & & 6.5 & \\
\hline Miami/Ft Lauderdale & 2.5 & 24 & 89 & & 0.5 & \\
\hline New Orleans & 4.5 & 100 & 55 & & 2.5 & \\
\hline New York & 24.9 & 100 & 90 & & 22.4 & \\
\hline Philadelphia & 7.6 & 100 & 89 & & 6.8 & \\
\hline Phoenix & 9.6 & 100 & 100 & & 9.6 & \\
\hline DC/Baltimore & 4.7 & 24 & 89 & & 1.0 & \\
\hline Grocery Store & & & & & & \\
\hline Atlanta & 2.2 & 98 & 44 & & 0.9 & \\
\hline Chicago & 10.6 & 87 & 100 & & 9.2 & \\
\hline Los Angeles & 33.5 & 77 & 81 & & 20.9 & \\
\hline Dallas/Ft Worth & 9.6 & 100 & 98 & & 9.4 & \\
\hline Houston & 9.2 & 100 & 98 & & 9.0 & \\
\hline Miami/Ft Lauderdale & 2.4 & 98 & 44 & & 1.0 & \\
\hline New Orleans & 3.4 & 100 & 98 & & 3.3 & \\
\hline New York & 11.9 & 100 & 100 & & 11.9 & \\
\hline Philadelphia & 3.9 & 100 & 100 & & 3.9 & \\
\hline Phoenix & 12.7 & 100 & 59 & & 7.5 & \\
\hline $\mathrm{DC} /$ Baltimore & 4.7 & 98 & 44 & & 2.0 & \\
\hline
\end{tabular}




\section{Appendix D}

\section{Metropolitan-Scale HVAC Energy and Monetary Data}

Metropolitan-scale HVAC annual electricity and net energy savings, peak electricity demand savings, and annual natural gas deficit were estimated by taking the product of the building-scale energy and monetary savings (Table B-19), the conditioned flat roof area (Table C-3), and the ratio of the local change in albedo to the change our simulations are based on. These are displayed in Table D-1. 
Table D-1. Metropolitan-scale HVAC annual electricity and net energy savings, peak electricity demand savings, and annual natural gas deficit estimates from light-colored roofing for residential and commercial buildings in 11 U.S. Metropolitan Statistical Areas.

\begin{tabular}{|c|c|c|c|c|c|c|c|c|}
\hline \multirow[b]{2}{*}{ metropolitan area } & \multicolumn{4}{|c|}{ gas furnace } & \multicolumn{4}{|c|}{ heat pump } \\
\hline & $\begin{array}{c}\text { electricity } \\
(\mathrm{MWh})\end{array}$ & $\begin{array}{c}\text { gas } \\
\text { (MBtu) }\end{array}$ & $\begin{array}{c}\text { net } \\
(\mathrm{k} \$) \\
\end{array}$ & $\begin{array}{l}\text { peak } \\
(\mathrm{kW})\end{array}$ & $\begin{array}{l}\text { electricity } \\
\text { (MWh) }\end{array}$ & $\begin{array}{c}\text { gas } \\
\text { (MBtu) }\end{array}$ & $\begin{array}{l}\text { net } \\
(\mathrm{k} \$)\end{array}$ & $\begin{array}{l}\text { peak } \\
(k W)\end{array}$ \\
\hline \multicolumn{9}{|l|}{ Residence Old } \\
\hline Atlanta & 87715 & 263524 & 5293 & 54066 & 4361 & 0 & 342 & 4076 \\
\hline Chicago & 83324 & 803988 & 5089 & 74419 & -246 & 0 & -38 & 1516 \\
\hline Los Angeles & 189111 & 432253 & 15892 & 196262 & 0 & 0 & 0 & 0 \\
\hline Dallas/Ft Worth & 173932 & 357129 & 11405 & 124746 & 5488 & 0 & 415 & 5192 \\
\hline Houston & 183349 & 231322 & 15772 & 85432 & 15470 & 0 & 1430 & 8450 \\
\hline Miami/Ft Lauderdale & 79868 & 4248 & 6372 & 44182 & 86082 & 0 & 6905 & 47875 \\
\hline New Orleans & 59524 & 80768 & 4207 & 14933 & 1567 & 0 & 123 & 462 \\
\hline New York & 28592 & 260832 & 2428 & 45585 & 2 & 0 & 0 & 454 \\
\hline Philadelphia & 45339 & 802454 & 440 & 88476 & -2228 & 0 & -279 & 4667 \\
\hline Phoenix & 140158 & 61102 & 14768 & 46912 & 71566 & 0 & 7640 & 25258 \\
\hline DC/Baltimore & 133195 & 691753 & 3580 & 116008 & 16564 & 0 & 1212 & 32724 \\
\hline \multicolumn{9}{|l|}{ Residence New } \\
\hline Atlanta & 27843 & 85313 & 1782 & 20270 & 4650 & 0 & 313 & 4755 \\
\hline Chicago & 16808 & 183726 & 933 & 12139 & -117 & 0 & -20 & 504 \\
\hline Los Angeles & 20254 & 39223 & 1768 & 20898 & 505 & 0 & 50 & 650 \\
\hline Dallas/Ft Worth & 58487 & 121811 & 3518 & 42656 & 2977 & 0 & 225 & 2724 \\
\hline Houston & 39058 & 52768 & 3362 & 28453 & 5428 & 0 & 505 & 4629 \\
\hline Miami/Ft Lauderdale & 17682 & 87 & 1380 & 7245 & 37583 & 0 & 3117 & 15400 \\
\hline New Orleans & 19850 & 26235 & 1393 & 9751 & 2818 & 0 & 227 & 1589 \\
\hline New York & 6856 & 70607 & 602 & 10103 & 5 & 0 & 1 & 98 \\
\hline Philadelphia & 4885 & 151444 & -349 & 10585 & -4076 & 0 & -523 & 4756 \\
\hline Phoenix & 37398 & 13148 & 3944 & 14170 & 49812 & 0 & 5445 & 19562 \\
\hline DC/Baltimore & 25553 & 153065 & 506 & 21252 & 6980 & 0 & 465 & 13028 \\
\hline \multicolumn{9}{|l|}{ Office Old } \\
\hline Atlanta & 4639 & 12287 & 269 & 3911 & 1438 & 0 & 107 & 1750 \\
\hline Chicago & 18606 & 133168 & 877 & 19288 & 75 & 0 & 6 & 1224 \\
\hline Los Angeles & 45208 & 36694 & 3838 & 35016 & 3552 & 0 & 312 & 3042 \\
\hline Dallas/Ft Worth & 12810 & 23982 & 714 & 6510 & 498 & 0 & 32 & 348 \\
\hline Houston & 13483 & 13162 & 966 & 9781 & 623 & 0 & 48 & 507 \\
\hline Miami/Ft Lauderdale & 7562 & 0 & 518 & 2728 & 3344 & 0 & 224 & 1224 \\
\hline New Orleans & 5841 & 5597 & 458 & 4788 & 284 & 0 & 24 & 262 \\
\hline New York & 17758 & 99252 & 1586 & 17229 & 782 & 0 & 102 & 2358 \\
\hline Philadelphia & 7632 & 62022 & 518 & 8530 & 28 & 0 & 5 & 1153 \\
\hline Phoenix & 4871 & 2297 & 433 & 1698 & 762 & 0 & 71 & 278 \\
\hline DC/Baltimore & 10642 & 45877 & 509 & 9879 & 2273 & 0 & 172 & 4450 \\
\hline \multicolumn{9}{|l|}{ Office New } \\
\hline Atlanta & 546 & 1261 & 32 & 383 & 480 & 0 & 36 & 472 \\
\hline Chicago & 3780 & 28560 & 175 & 4515 & 12 & 0 & 0 & 240 \\
\hline Los Angeles & 13260 & 4920 & 1140 & 10380 & 5017 & 0 & 443 & 4037 \\
\hline Dallas/Ft Worth & 3823 & 7268 & 213 & 2375 & 525 & 0 & 33 & 417 \\
\hline Houston & 4208 & 3253 & 296 & 3208 & 668 & 0 & 52 & 564 \\
\hline Miami/Ft Lauderdale & 877 & 0 & 58 & 209 & 1029 & 0 & 71 & 252 \\
\hline New Orleans & 1812 & 1412 & 148 & 1239 & 287 & 0 & 24 & 214 \\
\hline New York & 3898 & 22371 & 365 & 2557 & 572 & 0 & 63 & 1000 \\
\hline Philadelphia & 1596 & 15468 & 93 & 1742 & 0 & 0 & 0 & 672 \\
\hline Phoenix & 4193 & 1128 & 385 & 1320 & 1562 & 0 & 144 & 512 \\
\hline DC/Baltimore & 1173 & 5380 & 51 & 1054 & 686 & 0 & 52 & 1290 \\
\hline
\end{tabular}


Table D-1(Cont). Metropolitan-scale HVAC annual electricity and net energy savings, peak electricity demand savings, and annual natural gas deficit estimates from light-colored roofing for residential and commercial buildings in 11 U.S. Metropolitan Statistical Areas.

\begin{tabular}{|c|c|c|c|c|c|c|c|c|}
\hline \multirow[b]{2}{*}{ metropolitan area } & \multicolumn{4}{|c|}{ gas furnace } & \multicolumn{4}{|c|}{ heat pump } \\
\hline & $\begin{array}{l}\text { electricity } \\
(\mathrm{MWh})\end{array}$ & $\begin{array}{c}\text { gas } \\
\text { (MBtu) }\end{array}$ & $\begin{array}{c}\text { net } \\
(k \$)\end{array}$ & $\begin{array}{l}\text { peak } \\
(\mathrm{kW})\end{array}$ & $\begin{array}{l}\text { electricity } \\
\text { (MWh) }\end{array}$ & $\begin{array}{c}\text { gas } \\
\text { (MBtu) }\end{array}$ & $\begin{array}{l}\text { net } \\
(k \$)\end{array}$ & $\begin{array}{l}\text { peak } \\
(k W)\end{array}$ \\
\hline Retail Store Old & & & & & & & & \\
\hline Atlanta & 4944 & 3264 & 348 & 1776 & 992 & 0 & 75 & 395 \\
\hline Chicago & 24296 & 88825 & 1555 & 11274 & 0 & 0 & 0 & 0 \\
\hline Los Angeles & 67800 & 0 & 6060 & 22067 & 4348 & 0 & 388 & 1415 \\
\hline Dallas/Ft Worth & 28222 & 9697 & 1734 & 16082 & 1400 & 0 & 88 & 850 \\
\hline Houston & 28325 & 1883 & 2185 & 2411 & 1492 & 0 & 112 & 128 \\
\hline Miami/Ft Lauderdale & 6479 & 0 & 435 & 1779 & 1431 & 0 & 96 & 393 \\
\hline New Orleans & 12405 & 714 & 1029 & 3888 & 645 & 0 & 54 & 204 \\
\hline New York & 63977 & 159942 & 7138 & 39390 & 1266 & 0 & 163 & 1217 \\
\hline Philadelphia & 24411 & 80160 & 2424 & 18612 & 408 & 0 & 48 & 576 \\
\hline Phoenix & 7100 & 0 & 654 & 1111 & 60 & 0 & 6 & 9 \\
\hline DC/Baltimore & 9978 & 14852 & 618 & 2242 & 1668 & 0 & 121 & 490 \\
\hline Retail Store New & & & & & & & & \\
\hline Atlanta & 1242 & 216 & 93 & 402 & 408 & 0 & 31 & 132 \\
\hline Chicago & 6767 & 15540 & 467 & 1727 & 42 & 0 & 4 & 18 \\
\hline Los Angeles & 14849 & 0 & 1338 & 1640 & 2408 & 0 & 217 & 266 \\
\hline Dallas/Ft Worth & 2935 & 199 & 182 & 1211 & 0 & 0 & 0 & 0 \\
\hline Houston & 3436 & 0 & 269 & 697 & 0 & 0 & 0 & 0 \\
\hline Miami/Ft Lauderdale & 1690 & 0 & 117 & 455 & 563 & 0 & 39 & 152 \\
\hline New Orleans & 1518 & 0 & 126 & 510 & 0 & 0 & 0 & 0 \\
\hline New York & 7508 & 12128 & 866 & 2541 & 58 & 0 & 7 & 26 \\
\hline Philadelphia & 2758 & 7284 & 285 & 1940 & 22 & 0 & 2 & 23 \\
\hline Phoenix & 8771 & 0 & 801 & 1918 & 4715 & 0 & 431 & 1032 \\
\hline DC/Baltimore & 2627 & 1117 & 181 & 891 & 815 & 0 & 55 & 295 \\
\hline
\end{tabular}

\begin{tabular}{|l||r|r|r|r||r|r|r|r|}
\hline \multicolumn{1}{|c||}{ metropolitan Area } & \multicolumn{4}{c||}{ primary } & \multicolumn{3}{c|}{ secondary } \\
\cline { 2 - 8 } & $\begin{array}{c}\text { electricity } \\
(\mathrm{MWh})\end{array}$ & $\begin{array}{c}\text { gas } \\
(\mathrm{MBtu})\end{array}$ & $\begin{array}{c}\text { net } \\
(\mathrm{k} \$)\end{array}$ & $\begin{array}{c}\text { peak } \\
(\mathrm{kW})\end{array}$ & $\begin{array}{c}\text { electricity } \\
(\mathrm{MWh})\end{array}$ & $\begin{array}{c}\text { gas } \\
(\mathrm{MBtu})\end{array}$ & $\begin{array}{c}\text { net } \\
(\mathrm{k} \$)\end{array}$ & $\begin{array}{r}\text { peak } \\
(\mathrm{kW})\end{array}$ \\
\hline \hline School & & & & & & & & \\
Atlanta & 1466 & 6543 & 68 & 971 & 2328 & 12759 & 102 & 2107 \\
Chicago & 3857 & 52628 & 51 & 2132 & 7371 & 81619 & 177 & 6750 \\
Los Angeles & 8620 & 13987 & 671 & 4461 & 10038 & 47017 & 587 & 6692 \\
Dallas/Ft Worth & 5102 & 17271 & 264 & 1474 & 6349 & 36374 & 264 & 1786 \\
Houston & 6703 & 9983 & 468 & 1802 & 10470 & 24977 & 694 & 6308 \\
Miami/Ft Lauderdale & 2609 & 66 & 175 & 1092 & 3458 & 1758 & 229 & 860 \\
New Orleans & 3067 & 4908 & 233 & 1747 & 3392 & 11406 & 217 & 1396 \\
New York & 6757 & 64701 & 422 & 5490 & 10642 & 99332 & 740 & 10199 \\
Philadelphia & 2161 & 34746 & 56 & 5181 & 3686 & 42864 & 194 & 5916 \\
Phoenix & 4935 & 4500 & 435 & 1140 & 5433 & 14202 & 420 & 3648 \\
DC/Baltimore & 2886 & 21762 & 78 & 2288 & 3776 & 33352 & 91 & 3640 \\
\hline
\end{tabular}


Table D-1(Cont). Metropolitan-scale HVAC annual electricity and net energy savings, peak electricity demand savings, and annual natural gas deficit estimates from light-colored roofing for residential and commercial buildings in 11 U.S. Metropolitan Statistical Areas.

\begin{tabular}{|l||r|r|r|r||r|r|r|r|}
\hline \multicolumn{1}{|c||}{ metropolitan Area } & \multicolumn{4}{c||}{ hospital } & \multicolumn{3}{c|}{ nursing home } \\
\cline { 2 - 8 } & $\begin{array}{c}\text { electricity } \\
(\mathrm{MWh})\end{array}$ & $\begin{array}{c}\text { gas } \\
(\mathrm{MBtu})\end{array}$ & $\begin{array}{c}\text { net } \\
(\mathrm{k} \$)\end{array}$ & $\begin{array}{c}\text { peak } \\
(\mathrm{kW})\end{array}$ & $\begin{array}{r}\text { electricity } \\
(\mathrm{MWh})\end{array}$ & $\begin{array}{c}\text { gas } \\
(\mathrm{MBtu})\end{array}$ & $\begin{array}{r}\text { net } \\
(\mathrm{k} \$)\end{array}$ & $\begin{array}{r}\text { peak } \\
(\mathrm{kW})\end{array}$ \\
\hline \hline Health & & & & & & & & \\
Atlanta & 3361 & 18386 & 151 & 1530 & 207 & 251 & 13 & 108 \\
Chicago & 4513 & 86284 & -70 & 2291 & 12736 & 38187 & 869 & 5626 \\
Los Angeles & 20789 & 45182 & 1562 & 7330 & 7334 & 2427 & 639 & 3066 \\
Dallas/Ft Worth & 3259 & 13447 & 151 & 1424 & 4188 & 2183 & 257 & 1547 \\
Houston & 3083 & 6635 & 204 & 1163 & 4095 & 1170 & 308 & 1755 \\
Miami/Ft Lauderdale & 5045 & 1047 & 349 & 1288 & 366 & 2 & 25 & 108 \\
New Orleans & 1388 & 2875 & 98 & 343 & 1677 & 532 & 138 & 638 \\
New York & 4349 & 45053 & 289 & 2552 & 11342 & 27910 & 1254 & 8493 \\
Philadelphia & 1804 & 18596 & 93 & 1127 & 1451 & 22483 & 40 & 2205 \\
Phoenix & 3515 & 6592 & 292 & 1007 & 8568 & 1296 & 784 & 2656 \\
DC/Baltimore & 7031 & 59371 & 130 & 4166 & 443 & 951 & 26 & 225 \\
\hline
\end{tabular}

\begin{tabular}{|l||r|r|r|r|}
\hline \multicolumn{1}{|c||}{ metropolitan Area } & \multicolumn{4}{|c|}{ grocery store } \\
\cline { 2 - 5 } & $\begin{array}{c}\text { electricity } \\
(\mathrm{MWh})\end{array}$ & $\begin{array}{c}\text { gas } \\
(\mathrm{MBtu})\end{array}$ & $\begin{array}{c}\text { net } \\
(\mathrm{k} \$)\end{array}$ & $\begin{array}{r}\text { peak } \\
(\mathrm{kW})\end{array}$ \\
\hline \hline Grocery Store & & & & \\
Atlanta & 183 & 338 & 12 & 197 \\
Chicago & 1631 & 10411 & 86 & 1385 \\
Los Angeles & 5869 & 3536 & 505 & 2822 \\
Dallas/Ft Worth & 2327 & 2475 & 141 & 1590 \\
Houston & 1935 & 1358 & 142 & 1185 \\
Miami/Ft Lauderdale & 331 & 19 & 22 & 138 \\
New Orleans & 800 & 498 & 63 & 465 \\
New York & 1833 & 9080 & 181 & 1944 \\
Philadelphia & 632 & 8622 & 23 & 850 \\
Phoenix & 3468 & 843 & 312 & 1268 \\
DC/Baltimore & 556 & 1444 & 32 & 538 \\
\hline
\end{tabular}




\section{Appendix $E$}

\section{National Estimates of HVAC Energy and Monetary Savings}

The results for the 11 MSAs were extrapolated to estimate the savings in the entire United States. This extrapolation was done by two methods, first by accounting for the climatic variations of the savings and second by scaling to the national population.

\section{Extrapolation by Climate Zone}

The MSAs were located in three climatically distinct zones as defined in the Residential Energy Consumption Survey (RECS, 1995), where the hottest zone (5) contained the following MSAs: Phoenix, New Orleans, Houston, Dallas/Fort Worth, and Miami/Fort Lauderdale; zone (4): Atlanta and Los Angeles; and zone 3: Chicago, New York City, Philadelphia, and DC/Baltimore. Starting with the residential sector, for each zone we summed the savings and roof area (conditioned and non-conditioned) from the 11 MSAs. From RECS we obtained residential floorspace and the ratio of roof-to-floor area in each climate zone. The residential savings in each climate zone were calculated as the product of the zonal savings [A], floorspace [C], and ratio of roof-tofloor area $[\mathrm{D}]$, divided by the MSA roof area [B] as presented in Table E-1.

- Example of residential calculation: For the five MSAs in zone 5 we estimated residential dollar savings at $\$ 93 \mathrm{M}$ and roof area at $6 \mathrm{Bft}^{2}$. RECS floor space was $34 \mathrm{Bft}^{2}$ with a 0.80 ratio of roof-to-floor area in zone 5. The dollars saved in that climate zone were $\$ 435 \mathrm{M}$, and additionally, the savings from zone 4 and zone 3 were $\$ 107 \mathrm{M}$ and $\$ 52 \mathrm{M}$, respectively. The dollar savings in these three zones were estimated at $\$ 594 \mathrm{M}$.

A similar analysis was not applied to the commercial sector because the Commercial Energy Consumption Survey (CBECS, 1994) did not sub-divide the building stock by climate zone. Therefore, we took the zonal-level savings from the residential sector and scaled these by the ratio of MSA-sum-total (residential and commercial) to MSA-sum-residential savings to obtain total zonal-level savings. This is presented in detail in Table E-2.

- Example of residential and commercial calculation: For the five MSAs in zone 5 we estimated residential dollar savings at $\$ 93 \mathrm{M}$ and total (residential and commercial) at $\$ 113 \mathrm{M}$; also, zone 5 residential savings were $\$ 435 \mathrm{M}$. The total dollars saved in climate zone 5 were calculated as the ratio of $113-$ to- 93 , multiplied by $\$ 435 \mathrm{M}$, which resulted in $\$ 530 \mathrm{M}$.

Naturally, most of the savings were found in the hottest zone (5). This resulted in annual electricity savings of $11.1 \mathrm{TWh},(56 \%$ in zone $5,22 \%$ in zone 3 , and $22 \%$ in zone 3 ), annual net energy savings of $\$ 850 \mathrm{M}$, (63\% in zone $5,21 \%$ in zone 3 , and $16 \%$ in zone 3 ), an annual gas deficit of $28.2 \mathrm{TBtu}$, and peak electricity demand savings of $7.2 \mathrm{GW}$. 
Table E-1. Climate zone extrapolated estimates of annual national energy (M\$), electricity (GWh), gas (GBtu), and peak electricity (MW) savings potentials of reflective roofs in the residential sector.

\begin{tabular}{|c|c|c|c|c|c|c|c|c|c|c|c|}
\hline \multirow{2}{*}{ Climate Zone } & \multicolumn{4}{|c|}{$\begin{array}{c}{[\mathrm{A}]^{\mathrm{b}}} \\
\text { Savings in MSA }\end{array}$} & \multirow{2}{*}{$\mid \begin{array}{c}{[\mathrm{B}]^{\mathrm{C}}} \\
\text { Roof Area in MSA } \\
\left(\mathrm{Brt}^{2}\right)\end{array}$} & \multirow{2}{*}{\begin{tabular}{|c|}
$\begin{array}{c}{[\mathrm{C}]^{\mathrm{d}}} \\
\text { Floorspace in Climate Zone }\end{array}$ \\
$\left(\mathrm{Bft}{ }^{2}\right)$ \\
\end{tabular}} & \multirow{2}{*}{\begin{tabular}{|c|}
{$[D]^{e}$} \\
Ratio of Roof to Floor Area \\
\end{tabular}} & \multicolumn{4}{|c|}{$\begin{array}{c}{\left[\mathrm{E}=\mathrm{A}^{*} \mathrm{C}^{*} \mathrm{D} / \mathrm{B}\right]} \\
\text { Savings in Climate Zone }\end{array}$} \\
\hline & $(M \$)$ & $(G W h)$ & (GBtu) & $(\mathrm{MW})$ & & & & $(\mathrm{M} \$)$ & $(G W h)$ & (GBtu) & (MW) \\
\hline \multicolumn{12}{|l|}{ Zone 5} \\
\hline Phoenix & 32 & 299 & -74 & 106 & 1.059 & & & & & & \\
\hline New Orleans & 6 & 84 & -107 & 27 & 0.612 & & & & & & \\
\hline Houston & 21 & 243 & -284 & 127 & 1.524 & & & & & & \\
\hline Dallas & 16 & 241 & -479 & 175 & 1.739 & & & & & & \\
\hline Miami & 18 & 221 & -4 & 115 & 1.068 & & & & & & \\
\hline Total & 93 & 1088 & -948 & 550 & 6.002 & 34 & 0.80 & 435 & 4920 & -5280 & 2490 \\
\hline \multicolumn{12}{|l|}{ Zone 4} \\
\hline Atlanta & 8 & 125 & -349 & 83 & 1.029 & & & & & & \\
\hline Los Angeles & 18 & 210 & -471 & 218 & 4.135 & & & & & & \\
\hline Total & 26 & 335 & -820 & 301 & 5.164 & 29 & 0.74 & 107 & 1390 & -3410 & 1250 \\
\hline \multicolumn{12}{|l|}{ Zone 3} \\
\hline Chicago $f$ & 6 & 100 & -988 & 89 & 1.674 & & & & & & \\
\hline New York & 3 & 35 & -331 & 56 & 2.837 & & & & & & \\
\hline Philadelphia & -1 & 44 & -954 & 108 & 1.548 & & & & & & \\
\hline Washington DC & 6 & 182 & -845 & 183 & 1.714 & & & & & & \\
\hline Total & 14 & 361 & -3118 & 436 & 7.773 & 44 & 0.66 & 52 & 1340 & -11650 & 1630 \\
\hline \multicolumn{5}{|c|}{ Zone 2 (Ignored in these calculations) } & & 52 & & 0 & 0 & 0 & 0 \\
\hline \multicolumn{5}{|c|}{ Zone 1 (Ignored in these calculations) } & & 19 & & 0 & 0 & 0 & 0 \\
\hline \multicolumn{5}{|l|}{ Total } & 18.939 & 178 & & 594 & 7,650 & $-20,340$ & 5,370 \\
\hline
\end{tabular}

Notes:

a. Climate zones as defined in Residential Energy Consumption Survey (RECS, 1995).

b. This report, Table 5-1.

c. This report, Table C-3, includes non-conditioned and conditioned.

d. Residential Energy Consumption Survey, Table 3.5 (RECS, 1995).

e. Residential Energy Consumption Survey, Tables 3.1a, 3.4 (RECS, 1995).

f. Base on RECS climate zone definitions Chicago was classified as in zone 2. However, we included it in zone 3 because its climate is strongly influenced by Lake Michigan and is unlike the zone-2 continental climate type. In fact, the savings in Chicago were much like those of other MSAs in zone 3. 
Table E-2. Climate zone extrapolated estimates of annual national energy (M\$), electricity (GWh), gas (GBtu), and peak electricity (MW) savings potentials of reflective roofs in residential and commercial sectors.

\begin{tabular}{|c|c|c|c|c|c|}
\hline \multirow{2}{*}{ Climate Zone $\mathrm{a}^{\mathrm{a}}$} & \multirow[b]{2}{*}{ Row } & \multicolumn{4}{|c|}{ Savings } \\
\hline & & $(\mathrm{M} \$)$ & (GWh) & (GBtu) & $(\mathrm{MW})$ \\
\hline Zone 5 Savings ${ }^{b}$ & A & & & & \\
\hline Residential in $\mathrm{MSA}^{\mathrm{c}}$ & A1 & 93 & 1088 & -948 & 550 \\
\hline Residential and Commercial in $\mathrm{MSA}^{\mathrm{c}}$ & A2 & 113 & 1382 & -1201 & 665 \\
\hline Residential in Climate Zone ${ }^{c}$ & A3 & 435 & 4920 & -5280 & 2490 \\
\hline Residential and Commercial in Climate Zone & $\begin{array}{c}\mathrm{A} 4= \\
\mathrm{A} 2 * \mathrm{~A} 3 / \mathrm{A} 1\end{array}$ & 531 & 6250 & -6690 & 3010 \\
\hline Zone 4 Savings ${ }^{b}$ & $B$ & & & & \\
\hline Residential in $\mathrm{MSA}^{\mathrm{c}}$ & B1 & 26 & 335 & -820 & 301 \\
\hline Residential and Commercial in $\mathrm{MSA}^{\mathrm{c}}$ & $\mathrm{B} 2$ & 46 & 581 & -1044 & 425 \\
\hline Residential Savings in Climate Zone ${ }^{c}$ & B3 & 107 & 1390 & -3410 & 1250 \\
\hline Residential and Commercial in Climate Zone & $\begin{array}{c}\mathrm{B} 4= \\
\mathrm{B} 2 * \mathrm{~B} 3 / \mathrm{B} 1\end{array}$ & 180 & 2470 & -4340 & 1770 \\
\hline Zone 3 Savings ${ }^{b}$ & C & & & & \\
\hline Residential in $\mathrm{MSA}^{\mathrm{c}}$ & $\mathrm{C} 1$ & 14 & 361 & -3118 & 436 \\
\hline Residential and Commercial in $\mathrm{MSA}^{\mathrm{c}}$ & $\mathrm{C} 2$ & 37 & 654 & -4586 & 658 \\
\hline Residential in Climate Zone ${ }^{c}$ & $\mathrm{C} 3$ & 52 & 1340 & -11650 & 1630 \\
\hline Residential and Commercial in Climate Zone & $\begin{array}{c}\mathrm{C} 4= \\
\mathrm{C} 2 * \mathrm{C} 3 / \mathrm{C} 1\end{array}$ & 137 & 2420 & -17200 & 2460 \\
\hline National Savings & $\mathrm{D}$ & & & & \\
\hline Residential & $\begin{array}{c}\mathbf{D} 1= \\
\mathrm{A} 3+\mathrm{B} 3+\mathrm{C} 3\end{array}$ & 594 & 7650 & $-20,340$ & 5,370 \\
\hline Residential and Commercial & $\begin{array}{c}\mathrm{D} 2= \\
\mathrm{A} 4+\mathrm{B} 4+\mathrm{C} 4\end{array}$ & 848 & 11,140 & $-28,230$ & 7,239 \\
\hline
\end{tabular}

Notes:

a. Climate zones as defined in Residential Energy Consumption Survey (RECS, 1995).

b. Metropolitan areas in Climate Zone 5 include: Phoenix, New Orleans, Houston, Dallas, and Miami; in Climate Zone 4 include: Atlanta and Los Angeles; and in Climate Zone 3 include: Chicago, New York, Philadelphia, and Washington DC.

c. This report, Tables 5-1 and E-1. 


\section{Extrapolation by Population}

National estimates were also derived from scaling by population, where the 1990 population of the $11 \mathrm{MSA}$ was 70 million and the entire United States was 249 million. The savings estimates from the 11 MSA were increased by the ratio of 249 to 70 (3.56) and are shown in Table E-4. This resulted in a reduction of $9.3 \mathrm{TWh}$ in annual electricity use, $\$ 680 \mathrm{M}$ in annual net energy payments, and $6.2 \mathrm{GW}$ in peak electricity demand. The associated heating penalty was 24.5 TBtu. The reduction in peak electricity demand is the equivalent of 12 to 14 power plants each of $0.5 \mathrm{GW}$ capacity.

\section{Metropolitan-Scale and National HVAC Energy and Monetary Base Use}

The energy use for dark-colored roofs (base case) was estimated in order to understand the relative savings from light-colored roofs, and was calculated as the product of DOE-2 estimates and conditioned flat-roof area. Metropolitan-scale base energy use and monetary expenditures for single-story buildings are presented for groups of buildings: residences, offices, retail stores, and other buildings (primary and secondary schools, hospital, nursing home, and grocery store grouped together) in Table E-3. The base use was then grouped into residential and commercial buildings to scale the single-story estimates to multi-story by the average number of floors as shown in Table E-4. The average number of floors for residences was 2.3 for $11 \mathrm{MSA}$ (Source: AHS), 1.5 nationally (RECS, 1995), and 3.0 for commercial buildings nationally (CBECS, 1994). Note, the absolute savings estimated for single-story buildings are applicable to multistory buildings.

The relative savings that reflect actual building stocks, those with multiple floors, are shown in the final column of Table E-4. In the $11 \mathrm{MSAs}$ with the population extrapolation method we estimated a total electricity savings of $2.4 \%$, a gas deficit of $1.2 \%$, a net energy savings of $1.4 \%$, and a peak demand savings of $2.0 \%$, and nationally $2.9 \%, 1.6 \%, 1.8 \%$, and $2.5 \%$, respectively.

A comparison of our base use estimates with those of the EIA serves as a reality check. The annual national cooling electricity consumption in the residential sector was 0.51 QBtu (150 TWh) and in the commercial sector was 0.73 QBtu (210 TWh) in the early 1990s (EIA, 1993c). We estimated a base cooling electricity consumption of 144 TWh (within 4\% of EIA) for the residential sector and 172 TWh (within 18\% of EIA) for the commercial sector. Note, the commercial buildings we selected contained fewer building types than the EIA database. 
Table E-3. Metropolitan-scale HVAC annual electricity, natural gas, and net energy and peak electricity demand base use (dark roof) estimates for residential, office, retail store, and other (schools, health, and grocery store) buildings in 11 U.S. Metropolitan Statistical Areas.

\begin{tabular}{|c|c|c|c|c|c|c|}
\hline Metropolitan Area & Base Use & Residential & Office & Retail Store & Other & Total \\
\hline Atlanta & $\begin{array}{l}\text { Elec (GWh) } \\
\text { Gas (GBtu) } \\
\text { Net (M\$) } \\
\text { Peak (MW) }\end{array}$ & $\begin{array}{r}1669 \\
17136 \\
247 \\
1541\end{array}$ & $\begin{array}{r}169 \\
203 \\
14 \\
132\end{array}$ & $\begin{array}{r}154 \\
40 \\
12 \\
78\end{array}$ & $\begin{array}{r}161 \\
458 \\
15 \\
131\end{array}$ & $\begin{array}{r}2153 \\
17836 \\
287 \\
1882\end{array}$ \\
\hline Chicago & $\begin{array}{l}\text { Elec (GWh) } \\
\text { Gas (GBtu) } \\
\text { Net (M\$) } \\
\text { Peak (MW) }\end{array}$ & $\begin{array}{r}1121 \\
47042 \\
384 \\
1591\end{array}$ & $\begin{array}{r}417 \\
3317 \\
52 \\
454\end{array}$ & $\begin{array}{r}546 \\
1124 \\
52 \\
360\end{array}$ & $\begin{array}{r}516 \\
5307 \\
70 \\
558\end{array}$ & $\begin{array}{r}2599 \\
56790 \\
558 \\
2963\end{array}$ \\
\hline Los Angeles & $\begin{array}{l}\text { Elec (GWh) } \\
\text { Gas (GBtu) } \\
\text { Net (M\$) } \\
\text { Peak (MW) }\end{array}$ & $\begin{array}{r}1472 \\
11259 \\
214 \\
2492\end{array}$ & $\begin{array}{r}982 \\
142 \\
88 \\
901\end{array}$ & $\begin{array}{r}1166 \\
163 \\
105 \\
626\end{array}$ & $\begin{array}{r}858 \\
667 \\
80 \\
597\end{array}$ & $\begin{array}{r}4479 \\
12232 \\
487 \\
4616\end{array}$ \\
\hline Dallas/Fort Worth & $\begin{array}{l}\text { Elec (GWh) } \\
\text { Gas (GBtu) } \\
\text { Net (M\$) } \\
\text { Peak (MW) }\end{array}$ & $\begin{array}{r}4556 \\
25796 \\
502 \\
4047\end{array}$ & $\begin{array}{r}485 \\
438 \\
33 \\
401\end{array}$ & $\begin{array}{r}899 \\
140 \\
58 \\
473\end{array}$ & $\begin{array}{r}652 \\
1320 \\
48 \\
626\end{array}$ & $\begin{array}{r}6592 \\
27694 \\
641 \\
5548\end{array}$ \\
\hline Houston & $\begin{array}{l}\text { Elec (GWh) } \\
\text { Gas (GBtu) } \\
\text { Net (M\$) } \\
\text { Peak (MW) }\end{array}$ & $\begin{array}{r}3463 \\
12168 \\
394 \\
3298\end{array}$ & $\begin{array}{r}459 \\
174 \\
36 \\
341\end{array}$ & $\begin{array}{r}869 \\
99 \\
66 \\
377\end{array}$ & $\begin{array}{r}657 \\
696 \\
53 \\
554\end{array}$ & $\begin{array}{r}5448 \\
13138 \\
549 \\
4570\end{array}$ \\
\hline Miami/Fort Lauderdale & $\begin{array}{l}\text { Elec (GWh) } \\
\text { Gas (GBtu) } \\
\text { Net (M\$) } \\
\text { Peak (MW) }\end{array}$ & $\begin{array}{r}3974 \\
324 \\
325 \\
1779\end{array}$ & $\begin{array}{r}332 \\
1 \\
23 \\
170\end{array}$ & $\begin{array}{r}289 \\
21 \\
20 \\
90\end{array}$ & $\begin{array}{r}319 \\
33 \\
22 \\
164\end{array}$ & $\begin{array}{r}4913 \\
379 \\
389 \\
2203\end{array}$ \\
\hline New Orleans & $\begin{array}{l}\text { Elec (GWh) } \\
\text { Gas (GBtu) } \\
\text { Net (M\$) } \\
\text { Peak (MW) }\end{array}$ & $\begin{array}{r}982 \\
3595 \\
100 \\
796\end{array}$ & $\begin{array}{r}168 \\
63 \\
14 \\
125\end{array}$ & $\begin{array}{r}322 \\
37 \\
27 \\
137\end{array}$ & $\begin{array}{r}242 \\
269 \\
22 \\
207\end{array}$ & $\begin{array}{r}1714 \\
3964 \\
163 \\
1264\end{array}$ \\
\hline New York City & $\begin{array}{l}\text { Elec (GWh) } \\
\text { Gas (GBtu) } \\
\text { Net (M\$) } \\
\text { Peak (MW) }\end{array}$ & $\begin{array}{r}396 \\
17549 \\
205 \\
686\end{array}$ & $\begin{array}{r}546 \\
3045 \\
88 \\
560\end{array}$ & $\begin{array}{r}1284 \\
2115 \\
175 \\
879\end{array}$ & $\begin{array}{r}652 \\
6303 \\
121 \\
749\end{array}$ & $\begin{array}{r}2878 \\
29011 \\
589 \\
2875\end{array}$ \\
\hline Philadelphia & $\begin{array}{l}\text { Elec (GWh) } \\
\text { Gas (GBtu) } \\
\text { Net (M\$) } \\
\text { Peak (MW) }\end{array}$ & $\begin{array}{r}867 \\
35384 \\
351 \\
747\end{array}$ & $\begin{array}{r}162 \\
1328 \\
27 \\
148\end{array}$ & $\begin{array}{r}407 \\
939 \\
54 \\
274\end{array}$ & $\begin{array}{r}191 \\
2766 \\
39 \\
211\end{array}$ & $\begin{array}{r}1627 \\
40418 \\
471 \\
1381\end{array}$ \\
\hline Phoenix & $\begin{array}{l}\text { Elec (GWh) } \\
\text { Gas (GBtu) } \\
\text { Net (M\$) } \\
\text { Peak (MW) }\end{array}$ & $\begin{array}{r}4774 \\
4107 \\
541 \\
3312\end{array}$ & $\begin{array}{r}232 \\
15 \\
21 \\
164\end{array}$ & $\begin{array}{r}420 \\
32 \\
39 \\
182\end{array}$ & $\begin{array}{r}516 \\
256 \\
49 \\
334\end{array}$ & $\begin{array}{r}5943 \\
4410 \\
650 \\
3993\end{array}$ \\
\hline DC/Baltimore & $\begin{array}{l}\text { Elec (GWh) } \\
\text { Gas (GBtu) } \\
\text { Net (M\$) } \\
\text { Peak (MW) }\end{array}$ & $\begin{array}{r}3742 \\
37789 \\
583 \\
3045 \\
\end{array}$ & $\begin{array}{r}378 \\
861 \\
32 \\
308 \\
\end{array}$ & $\begin{array}{r}315 \\
144 \\
23 \\
183 \\
\end{array}$ & $\begin{array}{r}313 \\
1650 \\
32 \\
297\end{array}$ & $\begin{array}{r}4748 \\
40444 \\
670 \\
3833 \\
\end{array}$ \\
\hline Total & $\begin{array}{l}\text { Elec (GWh) } \\
\text { Gas (GBtu) } \\
\text { Net (M\$) } \\
\text { Peak (MW) }\end{array}$ & $\begin{array}{r}27016 \\
212149 \\
3847 \\
23336\end{array}$ & $\begin{array}{r}4330 \\
9588 \\
428 \\
3706\end{array}$ & $\begin{array}{r}6672 \\
4854 \\
630 \\
3657\end{array}$ & $\begin{array}{r}5076 \\
19725 \\
550 \\
4427\end{array}$ & $\begin{array}{r}43094 \\
246317 \\
5455 \\
35126\end{array}$ \\
\hline
\end{tabular}


Table E-4. Eleven metropolitan area sum total and population extrapolated national estimates of HVAC energy base use and savings resulting from light-colored roofs on residential and commercial buildings.

\begin{tabular}{|l|l||c||c||c||c|c|c|}
\hline \multicolumn{9}{|c|}{ Eleven Metropolitan Area Sum Total } \\
\hline \hline \multirow{2}{*}{ Building Type } & \multirow{2}{*}{ Savings } & HVAC Base & \# of & HVAC Base & \multicolumn{3}{|c|}{ HVAC Savings } \\
\cline { 6 - 8 } & & Single-Story & Floors & Multi-Story & $\Delta$ & \% Single & \% Multi \\
\hline \hline Residential & TWh & 27.0 & 2.3 & 62.1 & 1.78 & 6.6 & 2.9 \\
Commercial & TWh & 16.1 & 3.0 & 48.3 & 0.81 & 5.0 & 1.7 \\
Total & TWh & 43.1 & - & 110.4 & 2.60 & 6.0 & 2.4 \\
\hline Residential & TBtu & 212.1 & 2.3 & 487.9 & -4.89 & -2.3 & -1.0 \\
Commercial & TBtu & 34.2 & 3.0 & 102.6 & -2.00 & -5.8 & -1.9 \\
Total & TBtu & 246.3 & - & 590.5 & -6.89 & -2.8 & -1.2 \\
\hline Residential & \$B & 3.8 & 2.3 & 8.8 & 0.13 & 3.4 & 1.5 \\
Commercial & \$B & 1.6 & 3.0 & 4.8 & 0.06 & 3.8 & 1.2 \\
Total & SB & 5.5 & - & 13.6 & 0.19 & 3.5 & 1.4 \\
\hline Residential & GW & 23.3 & 2.3 & 53.7 & 1.29 & 5.5 & 2.4 \\
Commercial & GW & 11.8 & 3.0 & 35.4 & 0.46 & 3.9 & 1.3 \\
Total & GW & 35.1 & - & 89.1 & 1.74 & 5.0 & 2.0 \\
\hline
\end{tabular}

\begin{tabular}{|l|l||c||c||c||c|c|c|}
\hline \multicolumn{9}{|c|}{ National Extrapolation by Population } \\
\hline \hline \multirow{2}{*}{ Building Type } & \multirow{2}{*}{ Savings } & HVAC Base & \# of & HVAC Base & \multicolumn{3}{|c|}{ HVAC Savings } \\
& & Single-Story & Floors & Multi-Story & $\Delta$ & \% Single & \% Multi \\
\hline \hline Residential & TWh & 96.1 & 1.5 & 144.1 & 6.33 & 6.6 & 4.4 \\
Commercial & TWh & 57.3 & 3.0 & 171.9 & 2.88 & 5.0 & 1.7 \\
Total & TWh & 153.4 & - & 316.0 & 9.25 & 6.0 & 2.9 \\
\hline Residential & TBtu & 755.1 & 1.5 & 1132.7 & -17.39 & -2.3 & -1.5 \\
Commercial & TBtu & 121.8 & 3.0 & 365.4 & -7.11 & -5.8 & -1.9 \\
Total & TBtu & 876.8 & - & 1498.1 & -24.51 & -2.8 & -1.6 \\
\hline Residential & \$B & 13.5 & 1.5 & 20.2 & 0.46 & 3.4 & 2.3 \\
Commercial & \$B & 5.7 & 3.0 & 17.1 & 0.21 & 3.7 & 1.2 \\
Total & \$B & 19.6 & - & 37.3 & 0.68 & 3.5 & 1.8 \\
\hline Residential & GW & 82.9 & 1.5 & 124.4 & 4.59 & 5.5 & 3.7 \\
Commercial & GW & 42.0 & 3.0 & 126.0 & 1.64 & 3.9 & 1.3 \\
Total & GW & 125.0 & - & 250.4 & 6.19 & 5.0 & 2.5 \\
\hline
\end{tabular}




\section{Attachment 1}

\section{Residential White Roofing Shingles}

Source: Akbari, H., "Memo to Millard Carr, Attachment 2 - July 12, 1995," Heat Island Group, LBNL, 510-486-4287

\begin{tabular}{|l||c|l|}
\hline \multicolumn{1}{|c||}{ Shingle } & Albedo & \multicolumn{1}{c|}{ Availability } \\
\hline \hline Brown & 0.10 & Commonly used \\
\hline Typical white & 0.26 & Several manufacturers \\
\hline Premium white algaecide & 0.36 & Several manufacturers \\
\hline Typical 1960's white & 0.36 & Manufacturers can produce upon request \\
\hline Premium 1960's white & 0.40 & Manufacturers can produce upon request \\
\hline ISP prototype two-coat TiO white & 0.46 & $\begin{array}{l}\text { ISP has the process in place, it } \\
\text { can be produced within 3-6 months }\end{array}$ \\
\hline ISP prototype three-coat TiO white & 0.51 & $\begin{array}{l}\text { ISP has the process in place, it } \\
\text { can be produced within 3-6 months }\end{array}$ \\
\hline ISP prototype six-coat TiO white & 0.58 & $\begin{array}{l}\text { ISP needs to make modification to their process } \\
\text { line, it can be produced within 1-2 years }\end{array}$ \\
\hline
\end{tabular}

Two major manufacturers of granules for roofing shingles are ISP Minerals and 3M Industrial Minerals. The list of shingle companies can be obtained from either ISP or 3M.

ISP Minerals Products Inc. $\quad 3 \mathrm{M}$

34 Charles Street

3M Center, Building 209-1W-14

Hagerstown, MD 21740

St. Paul, MN 55144

310-733-4000

612-737-5536 


\section{Attachment 2}

\section{Linearity Property}

DOE-2 Simulated HVAC Annual Electricity and Net Energy and Peak Demand Savings from Light-Colored Roofs for a Base Case of 0.10 and Modified of $0.25,0.40 .0 .55$. and 0.70 . These prototypes and savings estimates were from a separate research task and were not identical to those described in this report, these results are presented only to highlight the linear relationship between savings and step-wise changes in roof aibedo (Source: Konopacki, S., Heat Island Group, LBNL. 510-486-6966).

\begin{tabular}{|c|c|c|c|c|c|c|c|c|c|c|c|c|}
\hline \multirow[t]{2}{*}{ Building \& Location } & \multicolumn{4}{|c|}{$\begin{array}{c}\text { Electricity Savings } \\
\left(\mathrm{kWh} / 1000 \mathrm{ft}^{2}\right)\end{array}$} & \multicolumn{4}{|c|}{$\begin{array}{l}\text { Net Energy Savings } \\
\left(\$ / 1000 \mathrm{ft}^{2}\right)\end{array}$} & \multicolumn{4}{|c|}{$\begin{array}{l}\text { Peak Demand Savings } \\
\left(\mathrm{W} / 1000 \mathrm{ft}^{2}\right)\end{array}$} \\
\hline & 0.25 & 0.40 & 0.55 & 0.70 & 0.25 & 0.40 & 0.55 & 0.70 & 0.25 & 0.40 & 0.55 & 0.70 \\
\hline $\begin{array}{l}\text { Residence Old w/ Gas Furnace } \\
\text { San Bemardino } \\
\text { LAX Airport } \\
\text { Santa Ana } \\
\text { LA Civic Center } \\
\text { Sacramento } \\
\end{array}$ & $\begin{array}{l}249 \\
149 \\
169 \\
195 \\
187\end{array}$ & $\begin{array}{l}512 \\
300 \\
338 \\
397 \\
384\end{array}$ & $\begin{array}{l}788 \\
440 \\
505 \\
601 \\
590\end{array}$ & $\begin{array}{r}1079 \\
588 \\
668 \\
808 \\
798\end{array}$ & $\begin{array}{l}27 \\
12 \\
18 \\
16 \\
10\end{array}$ & $\begin{array}{l}56 \\
25 \\
36 \\
34 \\
21\end{array}$ & $\begin{array}{l}86 \\
36 \\
53 \\
50 \\
32\end{array}$ & $\begin{array}{r}116 \\
47 \\
69 \\
66 \\
42\end{array}$ & $\begin{array}{l}1456 \\
1257 \\
1466 \\
1408 \\
1361\end{array}$ & $\begin{array}{l}3112 \\
2043 \\
2863 \\
2810 \\
2864\end{array}$ & $\begin{array}{l}5008 \\
3546 \\
4461 \\
4231 \\
4432\end{array}$ & $\begin{array}{l}7101 \\
4918 \\
6092 \\
5689 \\
6069\end{array}$ \\
\hline $\begin{array}{l}\text { Residence New w/ Gas Furnace } \\
\text { San Bernardino } \\
\text { LAX Airport } \\
\text { Santa Ana } \\
\text { LA Civic Center } \\
\text { Sacramento }\end{array}$ & $\begin{array}{l}84 \\
46 \\
54 \\
60 \\
62\end{array}$ & $\begin{array}{r}171 \\
93 \\
106 \\
125 \\
127\end{array}$ & $\begin{array}{l}259 \\
141 \\
162 \\
189 \\
193\end{array}$ & $\begin{array}{l}355 \\
190 \\
219 \\
256 \\
263\end{array}$ & $\begin{array}{l}9 \\
4 \\
6 \\
5 \\
3\end{array}$ & $\begin{array}{r}19 \\
8 \\
12 \\
11 \\
7\end{array}$ & $\begin{array}{l}29 \\
12 \\
18 \\
16 \\
10\end{array}$ & $\begin{array}{l}38 \\
16 \\
23 \\
22 \\
14\end{array}$ & $\begin{array}{l}607 \\
449 \\
495 \\
389 \\
511\end{array}$ & $\begin{array}{r}1253 \\
879 \\
1002 \\
860 \\
1035\end{array}$ & $\begin{array}{l}1840 \\
1335 \\
1548 \\
1345 \\
1576\end{array}$ & $\begin{array}{l}2573 \\
1755 \\
2099 \\
1844 \\
2136\end{array}$ \\
\hline $\begin{array}{l}\text { Office Old w/ Gas Fumace } \\
\text { San Bermardino } \\
\text { LAX Airport } \\
\text { Santa Ana } \\
\text { LA Civic Center } \\
\text { Sacramento }\end{array}$ & $\begin{array}{l}156 \\
120 \\
120 \\
120 \\
102\end{array}$ & $\begin{array}{l}305 \\
233 \\
251 \\
239 \\
215\end{array}$ & $\begin{array}{l}455 \\
347 \\
371 \\
359 \\
329\end{array}$ & $\begin{array}{l}616 \\
460 \\
484 \\
478 \\
442\end{array}$ & $\begin{array}{r}17 \\
10 \\
13 \\
10 \\
7\end{array}$ & $\begin{array}{l}32 \\
20 \\
27 \\
20 \\
14\end{array}$ & $\begin{array}{l}48 \\
29 \\
40 \\
30 \\
22\end{array}$ & $\begin{array}{l}65 \\
39 \\
52 \\
40 \\
30\end{array}$ & $\begin{array}{r}1078 \\
983 \\
900 \\
771 \\
741\end{array}$ & $\begin{array}{l}2168 \\
1750 \\
1788 \\
1562 \\
1734\end{array}$ & $\begin{array}{l}3181 \\
2741 \\
2642 \\
2473 \\
2639\end{array}$ & $\begin{array}{l}4335 \\
3407 \\
3623 \\
3210 \\
3564\end{array}$ \\
\hline $\begin{array}{l}\text { Office New w/ Gas Furnace } \\
\text { San Bemardino } \\
\text { LAX Airport } \\
\text { Santa Ana } \\
\text { LA Civic Center } \\
\text { Sacramento }\end{array}$ & $\begin{array}{l}78 \\
60 \\
66 \\
60 \\
54\end{array}$ & $\begin{array}{l}149 \\
120 \\
132 \\
131 \\
120\end{array}$ & $\begin{array}{l}233 \\
185 \\
197 \\
197 \\
185\end{array}$ & $\begin{array}{l}317 \\
251 \\
275 \\
269 \\
245\end{array}$ & $\begin{array}{l}9 \\
5 \\
7 \\
5 \\
4\end{array}$ & $\begin{array}{r}16 \\
10 \\
14 \\
12 \\
9\end{array}$ & $\begin{array}{l}25 \\
16 \\
21 \\
17 \\
13\end{array}$ & $\begin{array}{l}34 \\
22 \\
30 \\
23 \\
17\end{array}$ & $\begin{array}{l}541 \\
410 \\
483 \\
403 \\
415\end{array}$ & $\begin{array}{r}1093 \\
939 \\
856 \\
806 \\
908\end{array}$ & $\begin{array}{l}1656 \\
1407 \\
1521 \\
1263 \\
1396\end{array}$ & $\begin{array}{l}2304 \\
1861 \\
1980 \\
1692 \\
1880\end{array}$ \\
\hline $\begin{array}{l}\text { Residence Old w/ Electric Heat Pump } \\
\text { San Bernardino } \\
\text { LAX Airport } \\
\text { Santa Ana } \\
\text { LA Civic Center } \\
\text { Sacramento }\end{array}$ & $\begin{array}{l}192 \\
103 \\
118 \\
143 \\
116\end{array}$ & $\begin{array}{l}394 \\
196 \\
230 \\
279 \\
229\end{array}$ & $\begin{array}{l}595 \\
267 \\
330 \\
407 \\
341\end{array}$ & $\begin{array}{l}790 \\
333 \\
405 \\
521 \\
441\end{array}$ & $\begin{array}{r}23 \\
10 \\
14 \\
14 \\
9\end{array}$ & $\begin{array}{l}48 \\
19 \\
27 \\
28 \\
18\end{array}$ & $\begin{array}{l}72 \\
27 \\
40 \\
40 \\
27\end{array}$ & $\begin{array}{l}95 \\
33 \\
49 \\
52 \\
34\end{array}$ & & & & \\
\hline $\begin{array}{l}\text { Residence New w/ Electric Heat Pump } \\
\text { San Bemardino } \\
\text { LAX Airport } \\
\text { Santa Ana } \\
\text { LA Civic Center } \\
\text { Sacramento }\end{array}$ & $\begin{array}{l}68 \\
35 \\
42 \\
49 \\
38\end{array}$ & $\begin{array}{r}136 \\
69 \\
81 \\
96 \\
78\end{array}$ & $\begin{array}{l}204 \\
103 \\
122 \\
145 \\
116\end{array}$ & $\begin{array}{l}276 \\
136 \\
160 \\
192 \\
156\end{array}$ & $\begin{array}{l}8 \\
4 \\
5 \\
5 \\
3\end{array}$ & $\begin{array}{r}17 \\
7 \\
10 \\
10 \\
6\end{array}$ & $\begin{array}{r}25 \\
10 \\
15 \\
14 \\
9\end{array}$ & $\begin{array}{l}34 \\
14 \\
19 \\
19 \\
12\end{array}$ & & & & \\
\hline $\begin{array}{l}\text { Office Old w/ Electric Heat Pump } \\
\text { San Bemardino } \\
\text { LAX Airport } \\
\text { Santa Ana } \\
\text { LA Civic Center } \\
\text { Sacramento }\end{array}$ & $\begin{array}{r}144 \\
108 \\
114 \\
108 \\
78\end{array}$ & $\begin{array}{l}275 \\
209 \\
227 \\
215 \\
162\end{array}$ & $\begin{array}{l}401 \\
311 \\
329 \\
323 \\
245\end{array}$ & $\begin{array}{l}532 \\
413 \\
431 \\
424 \\
323\end{array}$ & $\begin{array}{r}16 \\
10 \\
13 \\
10 \\
6\end{array}$ & $\begin{array}{l}31 \\
19 \\
25 \\
19 \\
13\end{array}$ & $\begin{array}{l}44 \\
28 \\
37 \\
29 \\
20\end{array}$ & $\begin{array}{l}59 \\
37 \\
48 \\
38 \\
26\end{array}$ & & & & \\
\hline $\begin{array}{l}\text { Office New w/ Electric Heat Pump } \\
\text { San Bemardino } \\
\text { LAX Airport } \\
\text { Santa Ana } \\
\text { LA Civic Center } \\
\text { Sacramento }\end{array}$ & $\begin{array}{l}78 \\
54 \\
66 \\
60 \\
54\end{array}$ & $\begin{array}{l}143 \\
113 \\
120 \\
125 \\
102\end{array}$ & $\begin{array}{l}221 \\
173 \\
191 \\
191 \\
155\end{array}$ & $\begin{array}{l}299 \\
233 \\
251 \\
263 \\
197\end{array}$ & $\begin{array}{l}9 \\
5 \\
7 \\
5 \\
4\end{array}$ & $\begin{array}{r}16 \\
10 \\
13 \\
11 \\
8\end{array}$ & $\begin{array}{l}25 \\
15 \\
21 \\
17 \\
12\end{array}$ & $\begin{array}{l}33 \\
21 \\
28 \\
23 \\
16\end{array}$ & & & & \\
\hline
\end{tabular}

